FUNNY FEELINGS: TAKING LOVE TO THE CINEMA WITH WOODY ALLEN

by

\author{
Zorianna Ulana Zurba
}

Combined Bachelor of Arts

Wilfrid Laurier University, Waterloo, Ontario, 2004

Masters of Arts

Brock University, St. Catherines, Ontario, 2008

Certificate

University of Toronto, Toronto, Ontario, 2009

A dissertation presented to Ryerson University and York University
in partial fulfillment of the
requirements for the degree of
Doctor of Philosophy
in the Program of
Communication and Culture.

Toronto, Ontario, Canada, 2015

CCZorianna Zurba 2015 


\section{Author's Declaration}

I hereby declare that I am the sole author of this dissertation. This is a true copy of the dissertation, including any required final revisions, as accepted by my examiners.

I authorize Ryerson University and York University to lend this dissertation to other institutions or individuals for the purpose of scholarly research I further authorize Ryerson University and York University to reproduce this dissertation by photocopying or by other means, in total or in part, at the request of other institutions or individuals for the purpose of scholarly research.

I understand that my dissertation may be made electronically available to the public. 
Funny Feelings: Taking Love to the Cinema with Woody Allen

Zorianna Zurba, 2015

Doctor of Philosophy in Communication and Culture

Ryerson University and York University

\begin{abstract}
This dissertation utilizes the films of Woody Allen in order to position the cinema as a site where realizing and practicing an embodied experience of love is possible. This dissertation challenges pessimistic readings of Woody Allen's film that render love difficult, if not impossible. By challenging assumptions about love, this dissertation opens a dialogue not only about the representation of love, but the understanding of love. Rather than a Platonic love of unity, this dissertation combines the phenomenological work of Luce Irigaray and Jean-Luc Marion to describe a love of letting be. A love of letting be focuses on the lived experience of love as a phenomenology. In a love of letting be it is the intent of both lovers to regard each other as an unknowable whole, whom they must support and whose mystery they must protect. The transformations of four characters from Allen's cinema, Allan Felix of Play it Again, Sam, Alvy Singer of Annie Hall, Cecilia of The Purple Rose of Cairo, and Mickey Sachs of Hannah and her Sisters serve as illustrations of how coming to a love of letting be is possible. The four characters, the nervous romantics, come to understand a love of letting be through their experience in the cinema. Their experience in the cinema comes to enlighten their understanding and living of love as a love of letting be.
\end{abstract}




\section{Acknowledgements}

First and foremost, I would like to thank my supervisor, Dr. John Caruana for his kindness and encouragement. Many thanks to my committee members, Dr. Jonathan Rollins and Dr. Izabella PruskaOldenhof, for their close reading and attention to detail. I am especially indebted to Dr. Steven Shaviro for his insightful comments. And there is never quite enough acknowledgment of Jo Ann Mackie, whose calm strength reinforced the fortitude needed for 'the final push.'

"Writing sessions" with Catherine Jenkins and Natalya Androsova added kindness and laughter, as did working with Susan Lai whose weekly meeting maintained a solid pace. Thanks to Jessica Marion Barr, who has been a co-worker, comp comrade, and true friend. Thanks to Christian Martius for hanging out on Roncie and offering soundtracks. Many thanks to my long term German "pass partner," Jens Koblitz, for reminding why we do what we do. Special thanks to Marina Hess for always listening so warmly, offering the sunniest encouragement, and being willing to meet up for treats.

For making each day a little lighter, for making 'safe snacks' to take to the library, for the tireless and seemingly endless care, for listening my queries, for always being willing to get tacos before the movie, and for holding my hand through the scary parts, a special thanks to Marco Avolio.

And, to Nikola, whose tiny presence reminded me of the magic and the mystery of everyday life. I hope that one day the movies will fascinate you, as they do me. 
Dedication

For my favourite film companion, Marco, and our little cinephile, Nikola. 
Table of Contents

Author's Declaration $\quad$ ii

Abstract iii

Acknowledgements $\quad$ iv

Dedication $\quad$ v

$\begin{array}{ll}\text { Chapter 1: Introduction } & 1\end{array}$

Romance with the Cinema

Film-Philosophy $\quad 5$

Romantic Film-Philosophy 6

Romantic Phenomenological Film-Philosophy 7

$\begin{array}{ll}\text { Philosophical Interest in Woody Allen } & 10\end{array}$

Optimism, Pessimism, and the Space Between 11

It's a Joke? It's a Joke! $\quad 14$

Structure of Chapters $\quad 16$

Chapter 2: Looking for Love in Allen's Cinema 19

Making Love $\quad 19$

The Horrible and the Miserable $\quad 21$

$\begin{array}{ll}\text { The Sweet } & 23\end{array}$

The Sweet Unknown.

The Sweet City. $\quad 25$

$\begin{array}{ll}\text { The Repeat } & 27\end{array}$

The Beat $\quad 29$

The Cheat $\quad 30$

The Cheat and The Best Friend.

The Cheat and The Sister. 33

The Heat $\quad 35$

The Cold Feet $\quad 37$

What is This Thing Called Love?

Loving Otherwise $\quad 45$

Chapter 3: Going to the Cinema with Woody Allen 47

A Reality Check: You were Always Outta Step with the World 47

A Double-Movement of Cinematic Thinking $\quad 51$

Practicing Film-Phenomenology

A Relation Between Two $\quad 53$

Four Exemplary Cinephiles $\quad 59$

Allan: I Couldn't get a Girl into a Chair

Alvy: You're a Very Good Tennis Player

Cecilia: You'll Like This one, it's Romantic $\quad 70$

Mickey: I had a Great Time. It was Like the Nuremberg Trials 72

Chapter 4: Looking for Love in the Cinema with Woody Allen 76 
Radiant Nervousness

The Space of the Nervous Romance/Romantic Comedy $\quad 83$

Cultural Space of Transformation $\quad 86$

Art and Creativity $\quad 86$

Allan: Nothing a Little Bourbon and Soda Couldn't Fix $\quad 88$

Alvy: The Film Enters as a Condition of the art Form Itself

Cecilia: He's not Real, but you Can't Have Everything 97

Mickey: Do you Realize What a Loose Thread We're all Hanging by? 99

Anxiety or Homosexual Panic?

The Experience in the Cinema $\quad 102$

Chapter 5: Opening to Love in the Cinema with Woody Allen 107

$\begin{array}{ll}\text { The Love of the Cinephile } & 107\end{array}$

From I Loaf You to I L-L-L to You 109

Allan: She's a Real Tomato 118

Alvy: Will it Change my Wife?

Cecilia: He's not Real, but you Can't Have Everything 124

Mickey: It's Lucky I ran into you $\quad 127$

Another Possibility 130

Chapter 6: Conclusion 133

Contribution $\quad 135$

Review of Chapters $\quad 135$

Implications $\quad 137$

$\begin{array}{ll}\text { Suggestions for Future Research } & 137\end{array}$

$\begin{array}{ll}\text { Final Note } & 138\end{array}$

References 139 


\title{
Chapter 1: Introduction
}

\author{
"We must open our eyes in front of the screen, \\ we must analyze the feelings that transport us, \\ reason it out to discover the cause of that sublimation ourselves" \\ Louis Aragon, ([1918]1988, p. 166)
}

\section{Romance with the Cinema}

Arriving early to a Thursday night screening at the Revue, I find my place in the middle section, middle of the aisle. Sitting in the velvety chair, I unbundle myself. Scarf, jacket, and pants still wet from my walk over. Having volunteered for this theatre, I know that they need the sales from the concession stand. So, I allow myself some concession. My fingers gleam with butter as they rifle through the purple and orange cardboard box of popcorn.

Behind me, an awkward date is commencing. He self-identifies as a cinephile, and begins to tell her facts about the film's release, and why people think it is important. She offers him a few muffled sounds to suggest that she is listening. Having only recently understood going to the movie theatre as a solo pleasure, eavesdropping on this conversation affirms my position. In my solitude with my fellow cinephiles, I immersed myself in the situations before me. I did not realize at the time, but this visit inaugurated what became my own search for love in and through the cinema.

Thankful for the student discount that enabled me to afford more screenings, one summer I spent two to five nights of the week in the dark of the Cinematheque, then located at the AGO's Jackman Hall. There I developed a method of scribbling notes in the dark. Since my eyes did not move from the screen, I had to trust that my hand was doing something legible. When a friend would join me, they would be confused by urgency to arrive half an hour early (to secure a seat, of course), and found my note taking bizarre. One bold friend even took my notebook from me after we had finished 
watching Nagisa Oshima's Merry Christmas Mr. Lawrence (1983). He found thick descriptions of the mise-en-scène, and a few remarks about my bodily sensations. I explained that I was trying to document my continued love of the cinema in situ. Cinephilia is a love like any other, sometimes characterized by mastery, by imposition and obligation, but in the best instances it involves care, carefully watching and acutely listening.

I am forever, and eternally trying to understand my continued fascination with the moving image. My experience in the cinema, and, most importantly, my experience of the cinema illuminated to me an embodied thinking about love. This work is the attempt at expressing what the cinema enabled me to apprehend. It is toward this end, toward expressing the quiet, exuberant, vibrant love that the cinema facilitates that I endeavor. While my focus is on the cinema, the efforts undertaken here are not intended to exclude other media or modalities that facilitate a reconsideration of our approach to the other and to love. Indeed, this work could be considered an invitation to love.

As a cinephile, a lover of the cinema, I am one young learner among greats. Jean Epstein's writings on the cinema ooze with passionate, attentive love. Richard Abel (1988) describes Epstein's work as a kind of singing philosophy. But, Epstein does not simply sing, he revives himself after a deep swoon to caress the very thing that knocked him out. Epstein's writing in Bonjour Cinema (2012 [1921]) features not only commentary, but poetry in an attempt to express the ineffable quality of feeling experienced in the cinema. Epstein is no mere scopophile, but seeks another form of knowing in the cinema. The cinema, for Epstein, provides an experience of knowledge through love. Katie Kirtland (2012) writes, "sentiment - that is to say, love - is for Epstein a form of knowledge, one that provides a truth that is closer to the object than the truth provided by reason" (p. 102). As Epstein (2012) explains, "Nothing can explain this continuity between love and the world. Love creates itself in an ineffable and secret manner, in creating the creature. Invisible, it renders itself visible; incomprehensible, it makes 
itself comprehensible; supernatural, it gives itself a nature (from “Amour Indigent," p. 177, cited by Kirtland, 2012, p. 111). Coming to understand the world through love is the task of the cinema.

Like Epstein, André Bazin celebrates the love of the world evidenced in the cinema. Though Bazin is commonly understood as validating cinema's ability to replicate reality, I understand Bazin as celebrating the cinematic achievement of creating an experience of the world. In writing on neorealism, for example, Bazin pronounces that in creating a world, the cinema "is a phenomenology" (2005c [1967-1971], p.65). The experience of the cinema transforms our taken-for-granted relationship with the world; it brings to bare the world anew upon the body and in doing so, awakens our love for the world. For it is "Only the impassive lens," writes Bazin "in stripping the object of habits and preconceived notions, of all the spiritual detritus that my perception has wrapped it in, can offer it up unsullied to my attention and thus to my love" (2005a [1967-1971], p. 9). Robert Sinnerbrink (2013) argues that the love Bazin locates in the cinema inspires belief in the world, that is to say, in something outside our selves. Most importantly for the work undertaken in this study, for Bazin (2005c [19671971]), the cinema inspires love and he expresses this directly: "In my opinion, the cinema more than any other art is particularly bound up with love" (p. 72). Thus, the cinema, through its ability to create a world, offers another way of coming to understand the world through embodied experience.

The love that is implied by Epstein and Bazin automatically arises as a result of the relation with the screen. This suggests that love is not emotional nor psychological, though it does not preclude these forms of love. Rather, love is experiential; love is phenomenological. In a phenomenological consideration of love, love is considered to be a relational experience to the world and to the other. Love as a kind of relation is implicated in the love of the cinema. Cinephilia is not the mastery of knowledge of a film's production, distribution, or its aesthetic content. Cinephilia is not allowing one's self to be magically transported by the images on the screen. Cinephilia is feeling the full extent of the 
passions on-screen, while relating to the film, and recognizing that our participation in the film-our love of the film - is one of distance. In love, we must remain attuned to the sensations in our bodies, while coming to learn and appreciate the wonder of the other, who always escapes our knowing. In our deepest, most engaged moments with the cinema, our bodies attuned to every slight camera movement and change in volume, we remain acutely aware that the cinema is always too much. Love, like the cinema, should leave us refreshed.

Where Epstein and Bazin avail themselves to the experience of the cinema, to the love of the cinema, Woody Allen's films exemplify characters who struggle with permitting themselves unencumbered experience both in the cinema and in the world. Vulnerability is too uncomfortable for many of Allan's characters. However, their experience in the cinema motivates a transformation toward a new understanding of love.

This kind of love, what shall be referred to as a love of letting be, however, is lacking in popular discourse. Worse still, Luce Irigaray and Jean-Luc Marion write of love's complete disappearance from philosophical discourse. In its current popular form, "Love is defined by the ignorance of the other" (Marion, [1994] 2002, p. 157), and to proclaim I love you is ridiculous. As Marion (2007) writes no one says I love you because it is "like an obscenity or a derision, to the point where, in polite society (that of the educated), no one dares seriously to utter such nonsense" (p. 3). Marion (2007) charges philosophy with remaining silent on the topic of love

The result of all of these failed efforts is that ordinary people, or put another way, all those who love without knowing what love wants to say, or what it wants of them, or above all how to survive it - that is to say, you and I first and foremost — believe themselves condemned to feed on scraps: the desperate sentimentalism of popular prose, the frustrated pornography of the idol industry, or the shapeless ideology of that boastful asphyxiation known as "self-actualization". (p. 2)

Likewise for Irigaray (2002) philosophy has forgotten its origin as wisdom enlightened by love, and has understood itself only as the love of wisdom. What if, as Irigaray asks, the understood meaning of 
philosophy remained plural? That it was understood as both the love of wisdom, and the wisdom of love? Might we then be able to better acknowledge the internal relationship between "the body, the heart, and the mind" (Irigaray, 2002, p.2)? For Irigaray (2001), we lack a culture of love since our culture does not encourage intersubjective relationships that cultivate perception (p. 19-20). Simply put, "Our spiritual senses are not trained to love" (Irigaray, 2001, p. 42). These questions and concerns have animated this project which seeks to both contribute to a wisdom of (embodied) love while maintaining a love of (embodied) wisdom. If our spiritual senses are not trained to love and we lack a culture that encourages the cultivation of perception, then how might these practices be fostered? I argue that the cinema offers one way of reconsidering our embodiment and our embodied relationship with the other. The cinema is a site that invites us to open to the experience of love.

\section{Film-Philosophy}

Yet, not all of the educated remain silent on the topic of love. Love has not simply been left to the poets. It has been left to the filmmakers. Micheal Hanneke's Amour (2012) is an overwhelming ode to the sacred bond between spouses, and the challenge that they face to support and enable each other to live out their wishes. Decades earlier, Jean-Louis Trintignant starred opposite Anouk Aimée in Claude Lalouch's A Man and A Woman (1966). The film is about a couple who discover each other at their children's boarding school, but whose love is haunted by their undying love for their deceased spouses. Meandering through a train station as she is about to go home to Paris, Anne (Anouk Aimée) asks Jean-Louis (Jean-Louis Trintignant): "Why people don't take movies seriously?" Anne's question will be repeated again and again in academic discourse: can movies be taken seriously? Can they do more than illustrate philosophical ideas? Can movies do philosophy?

Within the emergent field of the philosophy of film there is debate as to whether a film can do more than merely illustrate philosophical ideas. Where philosophers such as Paisley Livingston (2006), 
Murray Smith (2006), and Thomas Wartenburg (2011) maintain that film can only illustrate concepts and rehearse ideas, philosophers such as Robert Sinnerbrink (2011), Tarja Laine (2011), Daniel Frampton (2006) and others have argued that film can not only provide a representation of philosophical ideas, but film can also contribute to philosophy in its own way. For film to be able to contribute to philosophy assumes that film can 'think'. Film-philosophers such as Sinnerbrink, Laine, Frampton, and Sobchack have revealed how film's thinking is tied to an intersubjective experience that is embodied, suggesting that the body is involved in the process of meaning-making during the cinematic experience. Where philosophers of film have focused on cinematic representation and filmphilosophers have focused on film-thinking, this dissertation extrapolates this inquiry to consider the influence of cinematic experience on personal experience. If film thinking is related to an embodied intersubjective experience, then what might this experience inform us about how we think and feel? Might film offer insight into what are presumed to be 'essentially human' experiences? How might the cinematic experience offer insight into the experience of love? In what follows, I will suggest that by inquiring into the cinematic experience, we can simultaneously inquire into the experience of love.

\section{Romantic Film-Philosophy}

My intention is not to apply philosophical texts to Woody Allen's films in order to read them, nor is it to use the films to illustrate philosophical ideas, but rather my intention is to find something new in the merger of philosophical ideas and cinema. Like John Mullarkey (2011), who argues against a "compare-and-contrast industry of film and philosophy" (p.87), I seek to avoid matching-up films with specific theories. Rather than simply apply a philosophical text as a kind of theoretical one size fits all tool, I seek to open up and bring to bare a new way of understanding Woody Allen's films, and what they say about love. More importantly, I seek to use phenomenology in order to inquire into the cinematic experience to consider how this experience can enlighten the experience of love. 
Robert Sinnerbrink (2011) has argued that little attention has been given to the question of "whether philosophy itself is transformed through its encounter with film" (p.28). Similarly, Vivian Sobchack (2011) recognizes the potential for mutual influence between film and philosophy. For Sobchack (2011), there is a "reciprocity between two questions: What might a particular philosophical tradition bring to the study of film? and What might film studies bring to the practice of philosophy?" (p.191) (original capitalization). At the intersection of film and philosophy, something new can be contributed to both fields. This work will contribute to both Woody Allen studies by offering new readings of his films, and will contribute to contemporary continental film-philosophy through a creative interpretation of the work of Luce Irigaray and Jean-Luc Marion, and a praxis of a love influenced by the experience of cinema.

Within the scope of positions on the relationship between film and philosophy, I argue, as Robert Sinnerbrink (2011) does, that film-philosophy "Like any marriage, it works best when film is acknowledged as equal yet different, rather than as unruly pupil or intellectual subordinate" (p.120). Sinnerbrink $(2013 ; 2011)$ has described his approach as romantic film-philosophy. The intention of romantic film-philosophy is to create something new. Romantic film philosophy "takes films to be capable of the aesthetic disclosure of novel aspects of our experience" (Sinnerbrink, 2011, p. 127). Further, romantic film-philosophy "provides a salutary way of overcoming the philosophical disenfranchisement of film. It attempts to do justice to the complexity of the film-philosophy relationship, allowing film to be philosophically self-reflective, while opening up the possibility that philosophy might be transformed through its encounter with film" (Sinnerbrink, 2011, p. 127). The cinema provides its own forms of experience and thinking, which can transform philosophy in distinctive ways. 


\section{Romantic Phenomenological Film-Philosophy}

In the introduction to Pursuits of Happiness, Stanley Cavell (1981) considers the bias with which cinema is approached: "Philosophers will naturally assume that it is one thing, and quite clear how, to let a philosophical work teach you how to consider it, and another thing, and quite obscure how or why, to let a film teach you this. I believe these are not such different things" (Cavell, 1981, p.1011). While Cavell does not reveal his own approach to considering filmic texts, his point is well taken: to uncover cinematic meaning is to be open to learning from our experience with cinema. Cavell echoes the work of early cinephile and cinema theorist, Louis Aragon ([1918] 1988), who argues that "Films are the only film school, remember that. It's there you'll find useful material, providing you can pick it out" (p. 167). This impetus is carried through to contemporary phenomenological and affective approaches to film-philosophy.

Phenomenology both informs the concept of love pioneered in this work, as well as the methodology used to analyze Allen's films. Since spectatorship is an intersubjective sharing of experience between ourselves and the cinema, it is essential to note how the film audio-visually prompts our attention and what sensations are affectively registered in the body. As Vivian Sobchack (2004) very clearly articulates, "the film experience is meaningful not to the side of our bodies but because of our bodies. Which is to say that movies provoke in us the 'carnal thoughts' that ground and inform more conscious analysis" [my emphasis] (p.73). By attending to the embodied experience, the film is interpreted bodily — which is to say pre-reflectively and without the analytic filtering of cognition. Adhering to such a methodology and taking up an affective spectatorship "involves consciously and voluntarily adopting an attitude that is open, erotic even, in allowing a form of emotional sensitivity to arise between the film and the spectator" (Laine, 2011, p.11). This method acknowledges the connective emotional entanglement that is formed between the spectator and the 
film. By attending to the texture and intensity of a film, we map out what anthropologist Kathleen Stewart (2007) refers to as a "contact zone" (p.13) that is expressed through writing as "an idiosyncratic map" (p.3) of our entanglement.

By taking up a phenomenological approach the researcher stays focused on attending to their embodied experience of the film, rather than relying on academic commentary or remaining in collusion with prevalent discourses. For Vivian Sobchack (2011), the phenomenological method should be "foundational for film and media studies" (p.192). Sobchack (2011) goes on to suggest that staying within the experience of the body is to "[insist] we dwell on the ground of experience before moving on to more abstract or theoretical concerns, that we experience and reflect upon our own sight before we (dare I pun?) cite others" (Sobchack, 2011, p.194). Maintaining a focus on the affective experience of the films and applying a phenomenological method, also works as a defense against the academic bias of the serious, or what Sam Girgus (2002) refers to as the sin of "being entirely too ponderous" (p. 7). In his own work, Girgus (2002) neither employs nor suggests a phenomenological approach; however, Girgus (2002) warns film students that “taking Woody Allen's somber side seriously should be considered an occupational hazard... if we take Allen too seriously, we miss the point of enjoyment and pleasure, we "[commit] a double sin of adding insult to injury by using a new critical terminology upon a comic talent that was meant for pure enjoyment" (p. 7). To remain within the experience of the body permits appreciating the tensions of Allen's serious humor.

Repetitive, sensitive viewings continue to inform my readings of Allen's films. However, even after countless encounters at the late night counter with Manhattan's (1979) Isaac (Woody Allen) and Mary (Diane Keaton), who carries her dachshund under her arm, this scene still eludes me (as it should). The slow mussing of Mary's hair becomes more and more peculiar. In one cut, perfect ringlets line her temples, in the next cut, they are slightly fuzzy and elongated down the sides of her face. 
Mary's hair could be an indicator of the level of her frazzled, nervous state, or of her exhaustion, or an oversight by the crew's stylist. Again, and again, I return to learn about the films that I love. This continual return, the repetitive viewing, a viewing that will never attain perfect knowledge_-and does not seek to - is not only a form of cinephilia, but more importantly, it is a form of love.

\section{Philosophical Interest in Woody Allen}

Tom Morris (2004) comments that philosophers love Woody Allen not only because he writes philosophers into his movies - "What other well-known filmmaker in our time has had philosophy professors as central characters in his films?" (p. ix), but also because "no one can lead us to the edge of the cosmic abyss like Woody, and then hits us with a joke that somehow makes it all easier" (p. ix). Sander Lee (1997) concurs that philosophers love Woody because so many of Allen's films take up philosophical questions. Lee (1997) suggests five reasons for studying Allen philosophically: Allen's characters face the existential dilemma of wanting a meaningful and ethical life while being aware of the life's meaninglessness and absurdity; Allen's characters play out the tension between hope and despair in the face of life's meaninglessness; Allen's characters represent the cultural tensions that exist between genders when trying to find love and romance; Allen's exploration and interest in the role of the artist and the arts to provide examples of moral responsibility as cultural values deteriorate; and, Allen's interest and suspicion of the role of psychology, specifically, in contemporary culture. Despite these readings of Allen's intentions toward philosophers-Hoesle (2007) points out that the Woody persona often reveals a "spiteful animosity" (p.32) towards intellectuals - yet "[despite] his antiacademic resentment, his greatest admirers are academics because they recognize that he X-rays their flaws and that he, and not they, ask the really, important, existential questions" (p. 32).

At first glance, Allen's interest in philosophy may appear cursory, and even vulgar; however, this is part of his schtick. Making light of, and even at times, misconstruing philosophical texts is a 
necessary part of Allen's work. Certainly, Allen does have an interest in philosophy. It is well documented that Allen's formal philosophical education ended at age 19; and, as a drop out of NYU, Allen's university career does not bode well for any in-depth knowledge of philosophical concepts (Bjorkmann and Allen, 1993; Lax and Allen, 2009; Lee, 1997). However, Allen is not a source for answers, but a source of inquiry. As Vittorio Hoesle (2007) observes, "Not that the Woody persona has any answers, but the mere fact that he continues to ask the right questions makes him fully human and therefore special" (p. 43). Perhaps, like Og, the out-of-this-world visitor in Stardust Memories (1980), who boasts of an IQ of 1600, tells Sandy Bates, the Woody Allen philosopher needs to be told: you're asking the wrong questions. The key to understanding Allen's questions is to examine what is satirized, somber, and sacred.

\section{Optimism, pessimism and the space between}

Lingering within Allen studies is the academic bias that only his serious work is of value, and that serious work is critical and pessimistic. Over and over again, like the petite, blond with the bugeyed round glasses in Stardust Memories whom Sandy greets stone-faced, academics commit the same crime: they divide Allen's films between the early funny ones, and the later serious ones. R.M.

Polhemus (2013) suggests that the opening of Melinda and Melinda (2004), in which writers sit around a table and argue if the essence of life is tragic or comic, sounds "like an inner dialogue going on in Woody Allen" (p. 118). For James B. South (2004), philosophical assessments of Woody Allen are divided into two types: either Allen as the product of Sartre, Nietzsche and of a scientific world view that points to the world as meaningless, or Allen as affirming moral values, "whether by taking a Kierkegaardian 'leap of faith' or by revealing 'the potential of the human soul for fulfillment in deeds of virtue and love" (p. 119). Sander Lee (1997), for example, offers his philosophical comments on Allen's serious films only, and is caught off guard by the criticism of over-intellectualizing in Hannah 
and Her Sisters (1986). Lee's (1997) analysis of Allen ignores understanding the inversions and criticisms of rationality made by Allen and, more importantly, renders difficult to read his films as articulating the role of experience in coming to locate meaning in living and loving.

With titles such as Brooklyn is not Expanding (Wernblad, 1992), You Mean My Whole Fallacy is Wrong (Conrad \& Skoble, 2004), Love, Sex, Death, and the Meaning of Life (Hirsch, 2001) and Woody Allen's Angst (Lee, 1997) authors emphasize the worry, neurosis, and fear in Allen's work. Save for Love and Death, which is a parody of Russian literature, Allen's own titles place their focus elsewhere. Allen's titles cite the names of the characters who serve as illustrations of life's conundrums: Annie Hall (1977), Zelig (1983), Alice (1990), Hannah and Her Sisters (1986), Broadway Danny Rose (1984), Vicky Cristina Barcelona (2008); or, offer reference to their (meta) cinematic nature: Play it again, Sam (1972), The Purple Rose of Cairo (1985), or offer toponyms: Manhattan, Manhattan Murder Mystery (1993), Vicky Cristina Barcelona, Midnight in Paris (2011), To Rome with Love (2012). Certain moments in Allen's film validate the dualism between optimism and pessimism. For example, in Annie Hall, when purchasing books on death and cats, Alvy tells Annie that life can be divided into the horrible and the miserable. These categories are perhaps the two trains that Sandy Bates (Woody Allen) parallels in the opening of Stardust Memories. Sandy is stuck on a train filled with sullen, long-faced commuters, while the other train is a festive hot spot with a vivacious blond wearing a party hat, (uncredited Sharon Stone) who makes eyes at Sandy.

Taking a level approach, Cecilia Sayad (2013) argues that Woody Allen "embodies the tension between auteur and popular cinema" (p.16) maintaining his practice as a stand-up comedian and as a serious filmmaker. Allan's dual co-existence in high and low forms of entertainment is played out in several of his films. The combination and juxtaposition of high and low art, on an aesthetic level, for Sayad (2013) "constitutes the director's personal signature" (p. 23). These contrasts are exemplified 
when Annie Hall's Alvy would rather watch the Knicks game than chat with the chairs from various philosophy departments, who are missing a table to complete their dining set, and by Manhattan Murder Mystery's Larry (Woody Allen), who demands to go home early to catch the Islanders game, and Mighty Aphrodite's (1995) Lenny (Woody Allen), who loves the Marx Brothers while his wife, Amanda (Helena Bonham Carter), runs an art gallery. For Woody Allen, popular entertainment is not assumed to be vacant or meaningless, and high art is not assumed to be meaningful or insightful.

While Allen scholars are trying to decide which of Allen's work to take seriously and which of Allen's work to laugh along with, scholars of the romantic comedy note how Allen's work has validated their object of study. In the introduction to their edited collection, Abbot and Jermyn (2009) write of how the director brought some seriousness to the much maligned genre of the romantic comedy with the release of Annie Hall and Manhattan. ${ }^{1}$

Certainly, Allen's work inquires into the complexities of life. His films give occasion with which to ponder the human condition. To read Allen's work optimistically is not a matter of reading Woody Allen's films otherwise - despite the plethora of authors who have read the films pessimistically; the films, I argue, provide equal evidence of optimistic readings. But, even to speak of love in terms of optimism and pessimism is to oversimplify and to skirt a deeper evaluation of love.

Nearly all of Allen's 45 films take up questions of love and romance. Allen has both considered love as a concept, and has reflected his love of the cinema in his films. Allen's thinking on love reflects popular philosophical and common sense notions of love. To understand Allen's cinema as characterized by a neurotic, frenetic, avoidance of love is to acknowledge only the better-known protagonists, typically played by Allen himself. Examples include characters such as Alvy Singer,

\footnotetext{
${ }^{1}$ Allen's work in the romantic comedy genre will form much of the later conversation around conventions of character transformation.
} 
Annie Hall and Allen Felix, Play it Again, Sam, who are resigned not to belong to any club that would have them as a member. This current study acknowledges the Allen trope of the nervous avoidance of love. It will inquire into nervousness as a way of exposing the wanting for love, and will examine the nervous romance as a trope within Allen's oeuvre. Further, Allen's love of the cinema is displayed in his use of intertextual references and techniques that reveal the magic of cinema, not to mention the multiple homages to the directors he admires (Antonioni, Bergman, Chaplin, Keaton, Fellini, the Marx Brothers, Welles). Most importantly, what several of Allen's films do, their "emotional core" (Laine, 2011), is invite the viewer to participate in a cinematic experience in which love is constituted with and between the spectator and screen, as both an on-screen romance and a screen romance. I will come to argue that it is in this position not only as spectator, but as cinephile, where an experience of love happens.

\section{It's a joke? It's a joke!}

The interplay of the silly and the serious, the high and the low, is common in Allen's work. One way of understanding this tension is to consider the impact and influence of Jewish culture, in particular Jewish humor, on Allen's work. ${ }^{2}$ Lawrence Epstein (2001) recognizes the contradiction and negotiation in Allen's work: Jew and Gentile, artist and comedian, serious and funny. For Epstein (2001) these are tensions, rather than problems that need to be solved. Epstein (2001) notes that "Allen didn't smuggle his content in; he loudly proclaimed his Jewishness. However troubled his relationship to that Jewishness might have been, he refused to hide it" (p. 203). Allen's own Jewishness is inflected in his characters, as Epstein (2001) explains Allen

\footnotetext{
${ }^{2}$ It has been well documented (Bjorkmann and Allen, 1993; Lax and Allen, 2009; Hirsch; 1990) that Allen worked in Borscht Belt resorts writing weekly sketch comedies, and had admired the work of his contemporary Jewish humorists.
} 
omit[s an] important way in which [their] Jewishness is defined. They see being Jewish as belonging to a particular ethnic group when they don't accept religious views, or belonging to a religious group when they don't accept religious views, or belonging to a particular ethnic group when they feel alienated from other members of that group, starting with their family. They don't, however, see being Jewish as inescapably belonging to a minority group with the particular psychological strains caused by their membership in that group and the pattern of thinking that ultimately emerges from such an emotional location. Allen's characters are not Jewish by religion or ethnicity but by their Jewish consciousness and temperament. (p.196)

The characters' Jewishness is most recognizable through their use of humor. Jewish humor includes common joke tropes such as the shift from the serious to the common, exemplified by Allen's joke "not only is there no God, but try getting a plumber on weekends" (Epstein, 2002, p. 299); the reversal of syntax "Handsome, he's not"; a question phrased as a clear rejection, such as "Should I pay for that meal?"; and, the use of questions to answer questions, often by simply nearly repeating the first question with a different inflection such as "Did you call your mother?" answered by "Did $I$ call my mother?" (Rosten, 1970, p.300). Allen also borrows the structure of Yiddish proverbs for jokes: "If we didn't have to eat, we'd all be rich" (Rosten, 1970).

The Woody Allen persona or the little man (Pogel, 1987) or "bumbling anti-hero" (Blake, 1995) or the Woodman (Spignesi, 1992) is based upon the Jewish figures of the nebbish and the schlemiel. The schlemiel is an unlucky and unstable person, and the nebbish is hopeless, feeble, and unsuccessful (Rosten, 1970). Menachem Feuer (2013) adds that the schlemiel "lives in a world of hope, but the world is against him" (p. 404). Drawing upon these two figures, Allen's work "maintains a tension between hope and despair" (Feuer, 2013, p. 404). However, unlike other literary schlemiels, Woody Allen's schlemiels transform themselves (Feuer, 2013, p. 404). It is precisely the transformation of the schlemiel, renamed here as the nervous romantic, that is of particular interest to this work.

Allen himself is often mistaken for the schlemiel or the nebbish. According to Pogel (1987) "fans have always had difficulty distinguishing between Woody Allen's little-man character and his 
creator" (p.17). Pogel (1987) goes on to note that unlike his several disorganized little-man characters, Allen leads a disciplined life and tries to control his environment in order to save energy for his work (p. 17-18). Cinematographer Gordon Willis described Allan as "one of the most meticulous men I have ever dealt with" (cited by Pogel, 1987, p.18-19). Indeed, as Epstein (2001) clarifies "For those who confuse Woody Allen with his comedy character, his film career might have seemed odd. A director, after all, couldn't afford to be a neurotic schlemiel" (p. 195). Strangely, Vittorio Hoesle (2007) remarks that if it seems as though all of Allen's characters "have something in common [it] is due not only to the fact that Allen's repertoire as an actor is quite restricted” (p.3). Hoesle's negative assessment of Allen's acting skills is surprising, given the range Allen demonstrates in his performance as Broadway Danny Rose's (1984) Danny Rose, Zelig's Leonard Zelig, and Scoop's (2006) Sandy Wasserman. Even to speak of Woody Allen is already to be speaking of a character, who chose to wear black plastic glasses because he thought they would be funny. In other words, Woody Allen is not Allan Konigsberg. But to decide and decipher between these men unnecessarily complicates Woody/Allan's attempt at retaining some privacy, and denies the cleverness with which Allen has developed as a kind of Allenesque type.

The Allenesque type or the Allenesque character will be used to refer to the character Allen typically plays, the nebbish schlemiel, who relies on humor and is often fearful, if not anxious. Stanley Cavell (1981) explains type as "the sense in which the creation of a (screen) performer is also the creation of a character — not the kind of character an author creates, but the kind that certain people are" (p. 29). The intention is not to equate this type with Allen himself, but to recognize the fluidity of the identities, and the commonality between the public identity that Allen assumes and the characters he plays. 


\section{Structure of Chapters}

In order to overcome assumptions that Woody Allen's cinema is simply pessimistic about love, the second chapter offers a deep exploration of the tropes of relationships in Allen's films. The representation of relationships are divided into categories of the sweet, the heat, the beat, the repeat, the cheat, and the cold feet. Particular characters, the sweet Cecilia of The Purple Rose of Cairo, and the cold feet of Allan, Play It Again, Sam, Alvy, Annie Hall, and Mickey, Hannah and Her Sisters are singled out for their exemplary transformations in their experience of love. These characters, these nervous romantics, are apprehensive of love and even feel excluded from love, but they are not aware of another option: a love of letting be. Their experiences as cinephiles enlighten their understanding of love.

As will be introduced in chapter 3, this work is characterized by a double-thinking: a cinephile is writing about cinephiles. Film-phenomenology is the primary methodology of my filmic analysis, and is also the framework for positioning the experience of the nervous romantics in the cinema. Filmphenomenology attends to the bodily experience in the cinema, and posits the relationship between cinephile and cinema to be an intersubjective relationship between two. This chapter also attends to describing the circumstances of the four exemplary nervous romantics, detailing their relationships both with their romantic and cinematic others.

The potential for the nervous romantic to transform their nervousness through their experience in the cinema is the focus of chapter 4 . Scholarship on the romantic comedy provides a way of considering the impact of space on the transformation of a character. The space of the cinema is both a metaphor and a physical place that enables the nervous romantics to attune to their embodiment, and their relation with the other. The nervous romantics possess an acute awareness of their bodily 
experiences, their sensitivity coupled with the intensity of the experience in the cinema illuminates their experience of love.

The final chapter explores the nervous romantic's transformation through their experience in the cinema. Likewise, the final chapter builds on the work of Jean-Luc Marion and Luce Irigaray to describe a love of letting be. 


\section{Chapter 2: \\ Looking for Love in Allen's Cinema}

The intention of this chapter is to offer an in-depth discussion of the various incarnations of love in the cinema of Woody Allen. The types of relationships occurring in Allen's cinema are grouped according to the types the sweet, the heat, the beat, the repeat, the cheat, and the cold feet. Where scholars have suggested that Allen is pessimistic about love, I argue that Allen's approach to love is nuanced, and offers both a rehearsal and critique of the popular conception of Platonic love. Most importantly, Allen's cinema offers the occasion to ponder another type of love: a love of letting be.

\section{Making Love}

Annie: "Have you ever made love high?" Alvy: "I get high every time we make love" Annie Hall

"Have you ever made love to a truly great woman?" Ernest Hemmingway, Midnight in Paris

The conceit of Allen's neurotic playboy is his inner nebbish and schlemiel. A vintage issue of Playgirl named Allen one of the world's sexiest men because he has "done more than anyone else to sexualize neuroticism" (Hoesle, 2007, p. 50). The neurotic playboy is best embodied by the oxymoronic namesake Max Kleineman, literally Max Little Man, of Shadows and Fog (1991). Max boldly jilted his former bride at the altar and was found making love to her sister in a broom closet. However, Max is bullied into joining a vigilante street gang, even though he is so terrified of the potential murderer lurking in the shadows that he asks this same ex-fiancée to hide him.

If we understand the joke as a form of thinking, a kind of illumination for Allen, then love and making love list high among his favorite topics of thinking. Sex is frequently discussed in Allen's films, but rarely shown, and even more rarely portrayed without a measure of comedy. Protagonists brag about breaking records (Manhattan) and becoming strong virile types (Annie Hall), but are typically 
found confused in bed (Love and Death (1975)), replaying baseball games to distract themselves (Play It Again, Sam), thinking about their wifes' sister (Hannah and Her Sisters), getting high (Annie Hall) or discussing the JFK assassination (Annie Hall). As Victor Hoesle (2007) rightly observes, Allen's comedies are about sexual deflation.

While sex in various incarnations is depicted: sex with a minor (Manhattan), sex with an animal (Everything You Always Wanted to Know About Sex* but were afraid to ask (1972)), sex with prostitutes (Shadow and Fog; Deconstructing Harry (1997); Mighty Aphrodite), the liaison is typically followed by a punch line. The Allenesque character may talk a big game about "beaver banging" (Deconstructing Harry), but never quite manages to make it work. Allan Felix (Woody Allen) in Play it Again, Sam, for example, is so clumsy that not even a nymphomaniac will sleep with him. Sexual afflictions are the source of much of Allen's comedy. The characters stutter, stumble, slurp, and salivate, or avoid sexual intimacy altogether. Not only does the comedy minimize any sexual arousal, but this "effacement is therefore antipornographic" (Hoesle, 2007, p.50). The function of making love in Allen's films is to illustrate the struggle that couples face to be intimate with one another.

In Hoesle's reading of Allen, the cure for sexual neuroticism is magic. As Hoesle (2007) explains: "techniques or desires cannot liberate people from their sexual inhibitions; the only thing that can accomplish this is the magical world of a midsummer's night, in which spirits help humans to become one with nature again (p. 52). The summer's night and nature, as I will later argue, serves to help only one character, Leopold (Jose Ferrer)(A Midsummer's Night Sex Comedy (1982)), while the rest of his characters require another form of liberation from the inhibitions of love and love making altogether. $^{3}$

\footnotetext{
${ }^{3}$ With the exception, of course, of Annie Hall, who gets high before making love to Alvy during their getaway in the Hamptons
} 


\section{The Horrible and The Miserable}

Liberation from inhibitions may set the nervous romantics free, but it does not release them from the pessimism of critical approaches to Allen's work. Unanimously, critics and commentators argue that love, within Allen's film, is an impossibility, a dream (Nichols, 2004). Joanna E. Raft (2013) argues, "what speaks to Allen is the inability to love" (p.227). In analyzing Allen's angst, Sander Lee (1997) applies Jean-Paul Sartre's theory of love to Annie Hall and Husbands and Wives (1992) illustrating how love is doomed to fail because one person is always attempting to possess the other. Lee allows for some complication of the dialectic between hope and despair, when he suggests that a Sartrean analysis of love in Annie Hall is incongruous. For Morris (2006), "Allen raises these classical expectations ironically, only to undermine them with nihilistic conclusions that challenge the possibility of romantic or social harmony" (p.53). The comedic tone in Allen's work is "too black" (p. 55) for Morris (2006), and renders love unreachable: "love is consigned to the realm of art, not life" (p. 55). For Mary P. Nichols (1987) and Maria del Mar Asensio Arostegui (2006) it is not love of the other, but love as self-love that is important for characters to gain the self-knowledge that propels them toward personal success. Strangely, even Celestino Deleyto (2006), the romantic comedy theorist, forgoes a discussion of love in his analysis of the end of Manhattan. Deleyto (2006) understands Isaac's realization that Tracy's (Mariel Hemmingway) face is what makes life worth living as an affirmation of life over "art and intellectual achievement" (p. 30). Coming to understand Isaac's love for Tracey is not on Deleyto's radar.

Many argue, adapting Alvy's punch line, that only the lucky achieve love and everyone chases after it because they need the eggs (Lee, 1997; Nichols, 2004; Morris, 2006; South, 2004). As James A. South (2004) succinctly explains: "love may invite trouble, but [Allen] knows exactly why people say 'I love you'. They have no choice" (p.131). South (2004) is slightly more hopeful, than other critics, 
stating that a central theme for Allen is "the human capacity for love, as well as the very fickleness of that capacity" (p.119). Allan's own commentary in interviews corroborates these readings. In a typewriter written response to Sander Lee (1997), Allen writes of chance:

In relation to the impossibility of authentic romantic commitment - this is a question of pure luck, the interfacing of two enormous complexities, and the delusion that it can be "worked at" is just that. Efforts by the parties may aid in a small way but have the same relation to the success of a relationship that a writing class has to a real reader. (p. 375)

Debating Allen's optimism or pessimism is reductive and forgoes an inquiry into what Allen does illustrate. In my estimation, Allen permits for greater flexibility than even he perhaps assumes. Efforts between people may aid in the success of their relationship, but successful communication is rare- this is exemplified by the conversations that occur in Annie Hall, as will be argued in chapter 4. Still, Allen suggests that love is relationship between two, two 'complexities' that are difficult to understand. The relationship between two complexities is a point that I will return to again. Between two unknowable subjects, two mysterious lovers, the best we can do is follow our intuition to love. To begin to understand loving relationships, I begin with a sketch of relationships that appear in Allen's work.

If, for Annie Hall's Alvy, life can be divided into the horrible and the miserable, then within the worlds of Allen's cinema, romantic relationships can be divided into the repeat, the beat, the sweet, the heat, the cheat, and the cold feet. The sweet are rarely represented young couple who are optimistic about their love. The repeat are the couple in which one partner attempts to mold the other according to their values and beliefs, similar to Pygmalion and Galatea. The cheat are the couple in which one partner is cheating either secretly or openly. The heat are the passionate, wild couple whose relationship is doomed to extinguish. The beat are the couple who no longer enjoy intimacy and are represented as in a malaise. The cold feet belong to the nervous romantic who is not able to express their love for their partner.

These tropes are certainly not isolated instances. The sweet is reflected in individuals who are 
optimistic about love, even if their relationship is not working. The sweet contains within it, elements of the nervous romance. And, the spark of the heat, or the wanting of the spark of the heat, is what leads to the cheat.

\section{The Sweet}

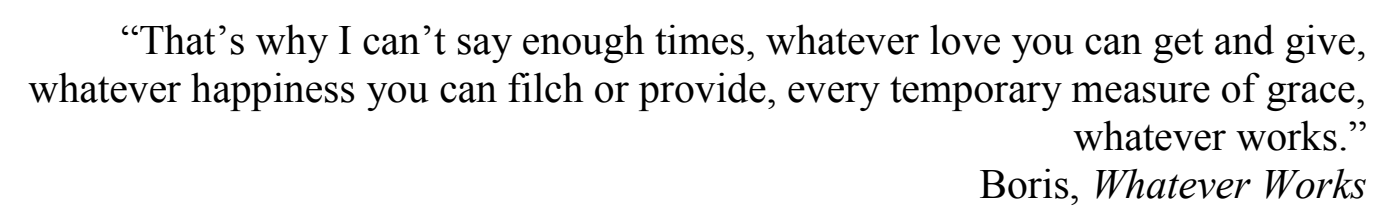

Within Allen's films there are individual characters who can be classified as typically sweet; they are optimistic, naive, well intentioned, supportive, kind, and loving in nature. For example: Emily (Anne Byrne Hoffman), Manhattan; Sally (Greta Gerwig), To Rome With Love (2012); Adrian (Mary Steenburgen), A Midsummer Night's Sex Comedy; and, Cecilia (Mia Farrow), The Purple Rose of Cairo. Allen uses these characters to demonstrate how steady everyday committed relationships are boring in comparison to trysts with the neurotic kamikaze woman who dives in and shakes up life (Husbands and Wives, Anything Else (2003), Manhattan, Stardust Memories). Despite their monotony, sweet relationships are depicted as having positive effects on people's lives by supporting them to transform.

The transformative power of love in a sweet relationship is best exemplified in Zelig. Leonard Zelig is the human chameleon, who changes himself in order to fit in. The source of his malady is the lack of love he experienced as a child. Eudora Fletcher, the gentle doctor assigned to him, cures him with her genuine love. The Purple Rose of Cairo's Cecilia longs for true love and a Hollywood ending, despite her depressive reality and dismal relationship to a man who gambles all day. She finds love in the movies. Hollywood Ending (2006) is a near screwball remarriage comedy, without the fast paced dialogue, in which the film-director protagonist, Val Waxman (Woody Allen) loses his sight and must 
over come his emotional blindness in order to be reunited with his former wife (Tea Leone) and son, the re-christened Scumbag X (Mark Webber). Despite the crankiness of the protagonist, Boris Yelnikov (Larry David), Whatever Works (2009) reveals the potentials of love that lie deep within people. When Celeste (Evan Rachel Wood) runs away from home and walks into Boris' life, his misanthropy is transformed. When Celeste's parents' relationship dissolves and they meet new partners, they each uncover their hidden potentials: her mother, Marietta (Patricia Clarkson), becomes an artist, and her father, John (Ed Begley Jr.) realizes his passion for the NRA was due to his closeted homosexuality. Love transforms and surfaces aspects of ourselves which were kept hidden.

Allen explores the ability to hide from our inner or 'true' selves, and our feelings. Protagonists in Curse of the Jade Scorpion (2001) and Alice are both put into altered states in order to uncover secret realities and gain self-knowledge. Betty Ann (Helen Hunt) who loves to loathe C.W. Briggs (Woody Allen) is hypnotized to love him, but the spell does not wear off. Mary P. Nichols (2004) similarly reads the hypnosis as allowing Betty Ann and C.W. access to an aspect of themselves that was not previously possible, and suggests that this new form of self-knowledge provides them the courage to love. Alice (Mia Farrow) visits Dr. Yang (Keye Luke) an herbalist in China town who offers her herbs, smokes opium with her and gives her invisibility drugs. The invisibility drugs help her to discover the confidence to flirt with a new man, and finally, leave her husband in pursuit of selfdiscovery.

\section{The Sweet Unknown.}

The great unknown features prominently in several Allen's films (Love and Death, Oedipus Wrecks (1989), Scoop, Magic in the Moonlight (2014)) and is manifested in figures such as psychics, magicians, and philosophers - arm chair or otherwise. In Oedipus Wrecks, a mother's figurative looming presence and pressure is made real, as she takes to the sky to watch over her son and 
Manhattan. Sheldon (Woody Allen) is intent on convincing his traditional Jewish mother (Mae Questl) to approve of his shiksa girlfriend, Lisa (Mia Farrow) and her two flaxen-haired sons. In an effort to bring them all together, he takes them to a see a magician, Shandu (George Shindler). When Shandu brings the mother on stage for a trick, she is dematerialized into the sky where she heckles and humiliates Sheldon. Desperate to have his mother returned back to earth, he turns to a psychic, Treva, (Julie Kavner). But, it is Treva's Jewish charm, and not her psychic abilities, which won over Sheldon and brought his mother back down to earth.

Likewise, in Magic in the Moonlight, an otherwise staunch rationalist is converted, not by magic, which he uncovers as a sham, but by love. Stanley (Colin Firth), who hides his stage presence as Wei Ling Soo, a Chinese magician, is summoned by an old friend, Howard (Simon McBurney) to uncover the truth behind a young American mystic, Sophie (Emma Stone). Sophie has convinced wealthy British families in the French countryside of her abilities, and Howard worries that she is scamming them for money. Slowly Stanley becomes convinced of Sophie's ability, and - to his own surprise — becomes smitten with her. Stanley realizes that Sophie's séances are a sham, and that Howard has set him up. Indeed, it is love that has bewitched Stanley.

\section{The Sweet City.}

The magic of the cities New York, Paris, and Rome serve as a backdrop for romance and selfdiscovery. In Everyone Says I Love You (1996), Von (Julia Roberts) believes the she has found the man of her dreams, and not simply some schmuck, Joe (Woody Allen), following the advice of his eavesdropping teen daughter, DJ (Natasha Lyonne). But, under the Parisian stars, after a Groucho Marx themed party, Joe learns to enjoy himself. Midnight in Paris' (2011) Gil Pender (Owen Wilson) is not seeking a romantic object, but he is a writer who seeks to infuse romance into his alienating marriage and dull life. His wish is granted when a magic carriage carries him off to carouse with the American 
expatriate writers hanging around Gertrude Stein's (Kathy Bates) salon.

To Rome with Love cautions against the power of external forces, in particular the city and the media, to alter relationships. Milly (Alessandra Mastronardi) and Antonio (Alessandro Tiberi) come to Rome from their small town hoping to begin a cosmopolitan life, but they become swept up in misadventures in the Eternal City. Antonio's family has set up meetings for him to meet the local elite. As they anticipate the arrival of Antonio's family, Milly wants to fix up herself so that she does not come across like the provincial village schoolteacher, which she is. As Milly wanders out into the streets to find a hairdresser, she looses her way. Antics soon ensue. Anna (Penelope Cruz), a vibrant prostitute, bursts into Antonio's hotel room demanding to have sex with him. As the two bicker about whether or not she has the right room, Antonio's conservative family rushes into the room to find them in various stages of undress. Antonio, too embarrassed to explain the circumstance, introduces Anna to them as Milly. Meanwhile, Milly stumbles about the city, and onto the set of her favourite soap opera. Both Antonio and Milly fall for the allure of the city and the promise of personal growth, and end up having sex with other people. Although they compromise their promise to each other, they are given a new passionate depth to their relationship.

In another plot line, media interventions bring intrigue to lives of Leopoldo (Roberto Benigni) and his wife. When Leopoldo is suddenly, and unknowingly, cast in the role of a celebrity, his life is turned upside down. After weeks of random television interviews, appearances at galas, and star treatment -including immediate reservations at restaurants and women waiting to make love to himLeopoldo returns to his unglamorous, simple and happy life. Leopoldo's momentary celebrity re-ignites his passion for a simple life. 


\section{The Repeat}

"Sinatra had glasses? You never said Sinatra had glasses. So, what are you saying? That I'm suffocating you?..."

Alvy Singer, Annie Hall

The repeat relationship is characterized by one lover attempting to replicate their values in the

other. This romantic replication occurs between Alvy and Annie, Annie Hall; Eve (Geraldine Page) and Arthur (E.G. Marshall), Interiors (1978); Isaac and Tracy, Manhattan; Fredrick (Max von Sydow) and Lee (Barbara Hershey), Hannah and Her Sisters; and, Boris and Celeste, Whatever Works. The tormented and misanthropic artist-cum-professor, Fredrick reminds Lee that there was a time that she wanted to learn everything from him: poetry, music and art, he has not yet taught her all she needs to know. Similarly, the misanthropic professor, Boris, attempts to teach Celeste about 'the world'; he turns to the camera to confide, "I wish I could do a Pygmalion on her."

For Sander Lee (2013), Allen's "infamous" (p. 510) Pygmalion-Galatea relationships occur between "a mentor and an apprentice that always end in the emotional suffocation of the apprentice and the abandonment by the mentor" (p. 510). Maurice Yacowar (1979) explains the Pygmalion story as "the story of an artist who falls in love with his own creation and loses her when she blossoms into full life" (p. 172). The beat relationship between Arthur and Eve began this way. Arthur credits Eve for developing him into the man he became; however, this eventually froze their emotional connection.

Annie Hall, for Sander Lee $(2013 ; 1997)$ is the ultimate expression of the Pygmalion-Galatea relationship. Alvy projects all of his values onto Annie in order to replicate himself in her. Alvy advocates Annie take college courses of his choosing, and to read books on topics that he is interested 
in. Simultaneously, through this form of projection, which Ernest Becker calls 'transference,' Alvy is able to avoid his fear of death. ${ }^{4}$

Like Alvy tutoring Annie, Isaac attempts to culture Tracy by taking her to art galleries and to art house movies. Tracy does stand her ground with Isaac, and even speaks in his terms. For example, when Isaac suggests he take her to a Veronica Lake film, she retorts, "you think I'm unaware of any cultural event pre-Paul McCartney." Tracy buys Isaac a harmonica to encourage him to try new things and to explore other creative avenues. When writer-professor Gabe (Woody Allen) begins to mentor, if not romance, his student Rain (Juliette Lewis) it appears as though another Pygmalion-Galatea relationship is about to form, but Rain it turns out, has her own plans for using his mentorship to her advantage.

Another potential Pygmalion-Galatea relationship occurs between Eudora (Mia Farrow) and Zelig (Woody Allen). While Eudora Fletcher may be doctor to the human chameleon, Leonard Zelig's, patient, their power relation is soon reversed. After several failed attempts to help Leonard, Eudora finally reaches him when she pretends that she has come to him for help. Once cured, Zelig takes his final role seriously and "insists on becoming the moral and spiritual advisor not only for Eudora but for society as a whole" (Lee, 1997, p.157).

In the case of Annie Hall, Yacowar (1979) writes, "Like the Pygmalion myth, it admits a double sympathy: one can appreciate the artist's loss, but one can also understand his creation's need for freedom and independence" (p.173). The repeat relationship assumes a power imbalance within the couple. Like Hegel's master-slave dialectic or Sartre's sadist-masochist pairing, the lover and beloved

\footnotetext{
${ }^{4}$ Ernest Becker, of course, is the author of The Denial of Death, the book that Alvy buys Annie instead of "those cat books" she is intend on purchasing. This is one of two books that Alvy insists on buying for her. The other is Philipe Aries' The Hour of Our Death.
} 
understand their identity in relation to the other. The emotional suffocation of these relationships leads to the beat.

\section{The Beat}

"What we have here is a dead shark"

Alvy Singer, Annie Hall

The beat, as Lee $(2013 ; 1997)$ argues, arises out of the Pygmalion-Galatea relationship. Arthur (E.G. Marshall) has grown tired of the ice palace that Eve (Geraldine Page) has carefully curated around him and his daughters in Interiors. The icy preservation has maintained the daughters' passions at bay: Renata's (Diane Keaton) poetry is stunted, "the intimacy of it embarrasses [her]"; Joey (Mary Beth Hurt) wants to create and procreate, but cannot; and, Flynn (Kristin Griffith) appears to be saved, if only for her cunning as an actress which offers her a secondary alluring façade. ${ }^{5}$ In Interiors, marriages seem exhausted, if only because they are exhausting: the efforts put toward restraining emotions has frozen any creativity and passion.

The beat is the tired relationship that appears to be drudgery for the parties involved. In Annie Hall, on the plane ride home from Los Angeles after acknowledging their differences, Alvy tells Annie that a relationship is like a shark, it must move forward. Alvy describes his relationship to Annie as a 'dead shark'. ${ }^{6}$ The beat is akin to the dead shark relationship; it is characterized by a lack of progression or stalemate. Both the romance is 'dead', but too one half of the couple may feel distant from

${ }^{5}$ Bert Cardullo (2006) writes that "Interiors should have been the tragedy (or even the comedy) of a man's attempt, alternately assisted or opposed by his daughters to win his own soul by ridding himself of their mother, his wife" (p. 137). For Cardullo, Arthur is a less sympathetic character than Eve, and so the film fails at allowing him to come into his own. Such a reading is harsh, and ignores Arthur's happiness with Pearl. In general, Cardullo's rendering of Interiors is bleak, and overly critical, for example: "That Allen should have been trapped by so obvious an error as to believe that you can depict tragedy by imitating the surface of it from someone else's (already superficial) version - this, I must say, is truly amazing" (p. 139). The 'someone else' that Cardullo refers to is, of course, Ingmar Bergman.

${ }^{6}$ Given Alvy's obsessive thoughts about Annie, they do not have a dead shark on their hands. They have a shark that will not die. 
themselves - their individuality is 'dead'.

Whether through suffocation of individuality or freedom or otherwise, long-term relationships are often under scrutiny in Allen's films, and even equated with death — the ultimate form of being beat. Alvy hesitates when Annie wants to move in, still wanting a life raft, and in You Will Meet a Tall Dark Stranger (2010) after 'seeing death' (metaphorically, and not literally as in some other Allen films in which the Grim Reaper makes a quick appearance), Alfie (Anthony Hopkins) becomes obsessed with youth. He takes to the gym, and takes up with Charmaine (Lucy Punch), a woman he engages after paying her for sex several times. In the wake of his rebirth, Alfie leaves behind Helena (Gemma Jones) who turns to the tarot and the occult for guidance. Alfie soon comes to his senses, and returns to Helena.

Being beat is inflected in several other Allen couplings: Another Woman's (1988) Marion (Gena Rowlands) has not had a night alone with her husband, Ken (Ian Holm), for quite for some time; Annie Hall's Alvy avoids intimacy with his wives before inevitably leaving them, Matchpoint's (2005) Chloe (Emily Mortimer) is the up-ward mobile choice for Chris (Jonathan Rhys Meyers), but does not hone in on Chris' desire; and, Vicky Cristina Barcelona's (2008) Judy (Patricia Clarkson) secretly longs to be taken out of her situation with Mark (Kevin Dunn) in Barcelona, but loves her lifestyle too much. Passion may fizzle, but the death of romance begins with the unequal footing between the lovers of the repeat.

\section{The Cheat}

Rain: "The way your people just casually have affairs like that, that's..." Gabe: "Well, the book doesn't condone affairs. You know, I'm exaggerating for comic purposes." 
Allen echoes Freud's claims that an injured third party is a way of increasing sexual interest. "An obstacle is required in order to heighten libido" claimed Freud ([1912] 1977, p. 256) "where natural resistances to satisfaction have not been sufficient men have at all time erected conventional ones so as to the able to enjoy love" ([1912] 1977, p. 256-257). Obstacles of convention in Allen's films have included: a friend's mistress (Manhattan), the partner of a friend (Play It Again, Sam, A Midsummer's Night Sex Comedy, Manhattan Murder Mystery), the friend of a partner (Anything Else, To Rome with Love, Melinda and Melinda), the sister of a wife (Hannah and Her Sisters, Interiors), and the partner of a spouse's sibling (Matchpoint).

Indeed, a majority of the passionate sex scenes or passionate sex alluded to in Allen's films feature a cheating duo. Elliot and Lee lie in a hotel bed enjoying the afterglow of "perfect" sex in Hannah and her Sisters. Love and passion become particularly intertwined in Matchpoint. Chris Wilton and Nola Rice (Scarlett Johansson) are frequently depicted massaging each other with baby oil and having afternoon sex. When Nola conceives a child she claims the baby was conceived out of "pure love".

\section{The Cheat and the Best Friend.}

The best friend is often involved or implicated in cheating relationships, such as in Manhattan Murder Mystery, A Midsummer's Night Sex Comedy, Manhattan, and Another Woman. Anything Else, To Rome with Love, Melinda and Melinda feature a cheat involving a best friend who is also a kamikaze woman; these films will be discussed in a later section. Another Woman features a cheat involving the best friend of a spouse. Manhattan Murder Mystery's Ted (Alan Alda) harbors feelings for Carol (Diane Keaton). Ted emphasizes his feelings any chance he has, even though he is dating another woman: "She's not my first choice. Of course, I can't have my first choice... You know you were my first choice." This crush, however, has little impact on the marriage between Larry (Woody) 
and Carol, who tease each other about their mutual jealousy.

In A Midsummer Night's Sex Comedy the heat of the summer night and the natural setting encourage old flames and spark new interests between friends. Andrew (Woody Allen) and Adrian are preparing to host some friends for the weekend: Maxwell (Tony Roberts), Andrew's close friend and philandering physician; Dulcy (Julie Hagerty), his nurse-cum-guest; Leopold (Jose Ferrer), a metaphysics professor; and, Leopold's soon to be wife, Ariel (Mia Farrow). When Andrew realizes that the Ariel who Leopold is marrying is none other than Ariel Waymouth, who had long regretted not making love with as a teen, his old flame is awakened. Romantic antics ensure as the 6 share the home. Maxwell tries to bed Dulcy. Leopold asks Dulcy to sleep with him in the woods. Andrew and Maxwell both try to win the affection of Ariel. Adrian seeks sex advice from Dulcy. And, finally, it is revealed that despite her shy demeanor, Adrian had made love with Maxwell, and was so deeply wracked with guilt that she was unable to make love to Andrew. In spite of the web of attractions, the magic of the summer night rekindles Adrian and Andrew's spark.

In Manhattan, a flurry of feelings confuses relations. Yale (Michael Murphy) and Emily have a seemingly happy, stable, long-term relationship. Emily presses Yale to move to Connecticut and have a child, but he uses Isaac as an excuse to stay in the city, in order to maintain his relationship with Mary (Diane Keaton). Meanwhile, Isaac is romancing the 18 year-old Tracy. Isaac claims he does not understand while Yale likes to "diddle this little yo-yo," yet after a chance encounter with Mary at a fundraiser, which is followed by a moonlit walk by the Hudson River, he begins to desire his best friend's mistress. Yale backs away from Mary, then encourages Isaac to pursue her. Yet, once Isaac and Mary seem to have comfortably established their relationship, Yale wants Mary back. The romantic maneuvering with Yale and Mary, prompts Isaac to come to terms with his own feelings, consider ethics in romance, and realize his love for Tracy. 


\section{The Cheat Encounters the Sister.}

While the Allenesque character typically makes himself out to be the playboy, "the virile aging gray" as Alvy describes, he typically does not win over the women he sets out to woo. That is with the exception of Shadow and Fog's Max Kleineman, who was about to be married and was discovered making love to the sister of his fiancée.

A trio of sisters is featured in Allen's films Interiors, and Hannah and Her Sisters. Diane Snow (2006) has described Hannah and her Sisters and Interiors as optimistic and pessimistic versions of each other. In both of these films the husband of the eldest sister is frustrated in his marriage, and is attracted to the youngest sister. The desperation of the husband becomes brutally aggressive in Interiors, and takes on a teenage-like crush in Hannah and Her Sisters. In both Interiors and Hannah and Her Sisters, the eldest sister is not aware of what is going on, and the marriage is not dissolved as a result of the husband's actions.

Interiors' Fredrick (Richard Jordan) is a failed playwright who is living in the shadow of his wife's successful poetry career. Frederick soothes himself with alcohol; as Renata chides, “drinking himself unconscious is one cliché of a writer that he has no problem with." Frederick speaks only with distain for Renata's family, particularly Flyn, describing her a "sexy one," but "form without content." On the eve of the wedding between Arthur and Pearl (Maureen Stapleton), Frederick maintains a constant steady stare at Flyn. When Flyn steals away to hide in a car parked in the garage for some privacy where she sniffs cocaine, Frederick interrupts her. Climbing into the car, Frederick leans over and kisses her. Flyn protests, and tells him he is drunk. Frederick aggressively pursues her, pathetically begging, "do you know how long its been since I've made love to a woman I didn't feel inferior to?" Flyn runs out of the car, but Frederick attempts to force himself on her. Flyn escapes Frederick's pursuit. 
Hannah and Her Sisters begins with a lingering close up on Lee's face, and softened, interior voice sighing, "God, she's beautiful." Elliot (Michael Caine) lovingly gazes through his thick yellowtinged wire-framed glasses across the dining room, set for Thanksgiving dinner. But the woman he directs his attention at is not his wife, Hannah, but her sister, Lee. Elliot's feelings seem to go unnoticed by most, with the exception of the dark, brooding, tormented painter, Frederick (Max von Sydow), Lee's domestic partner who warns her that "Elliot lusts after [her]."

Elliot becomes obsessed with Lee and makes any excuse to be close to her: he brings Dusty (Daniel Stern), a musician to Lee and Fredrick's place to consider some of Fredrick's art; and, he lingers on a corner near their loft in order to casually run into her. Waiting on the corner proves successful, and Elliot invites Lee into a bookshop where he insists on purchasing a book of e.e. cummings' poetry for her. This particular book contains a poem, on page one hundred and twelve, which he claims, reminds him of her. Lee later reads the poem, while in bed, and guiltily calls Elliot, who too is in bed, and beside Hannah.

Elliot's direct flirtation is successful, and soon he and Lee are making love in a hotel room. And, while Hannah is unaware of the affair, she is also the focus of their conversation. Lee frets that "she couldn't compete with Hannah" in the bedroom, but Elliot claims the lovemaking was "perfect."

Their romance extends over the course of a year, and at the next Thanksgiving dinner, Lee confronts Elliot to finally leave Hannah. Elliot is panicked and stalls. He later confesses to his psychoanalyst that he "can't fathom [his] own heart." By the time of the following Thanksgiving dinner, Lee is married to her former professor, and Elliot's internal dialogue expresses his relief and dismay that he was "such a fool."

In these examples, cheating seems to become a sort of thrill best enacted with a close relation. However, on closer inspection, for Elliot and Frederick, cheating is a form of seeking security in an 
uncertain world. Too, it is a way of making oneself feel needed. Elliot, and then later Holly (Diane Wiest) and Lee, complains that Hannah is too self-sufficient. Likewise, Frederick longs to feel valued.

\section{The Heat}

Og: Hey look, I'm a superintelligent being. By earth standards I have an IQ of sixteen hundred and I can't even understand what you expected from that relationship with Dorrie.

Sandy: I loved her

Og: Yeah, I know, and two days a month she was the most exciting woman in the world, but the rest of the time she was a basket case.

Stardust Memories

In Husbands and Wives, Gabe describes to his young protégé, Rain, his penchant for kamikaze women who are self-destructive and crash into you. The kamikaze woman is a dangerous combination of attractive, sexually adventurous, manipulative, and unstable. Gabe is not alone in his desire. Manhattan's Isaac was warned by his analyst about his ex-wife Jill (Meryl Streep), but she was so beautiful, "so [he] got another analyst." Stardust Memories' Sandy Bates engages in a prolonged relationship with the tormented and beautiful Dorrie (Charlotte Rampling). The destabilization force of the kamikaze woman has an enigmatic magnetism that draws people in, and infuses everyday life with surprises, which provides the Allenesque character a momentary avoidance of life's larger looming uncertainty. The kamikaze women's instability overshadows the uncertainty, nervousness, and insecurity of the Allenesque character.

Jerry Falk (Jason Biggs), Anything Else; Jack (Jessie Eisenberg), To Rome with Love; and, Hobie (Will Ferrell) Melinda and Melinda, cheat on their wives with a kamikaze woman, who happens to be the best friend of their wife. Jerry Falk leaves his loving relationship with sweet, but boring Brooke (KaDee Strickland) for her fiery, wild friend, Amanda (Christina Ricci). Amanda ends up withholding sex before finally cheating on Jerry, and leaving him. Aware of her friend's reputation, 
Sally (Greta Gerwig) warns Jack before the arrival of the freshly broken-hearted friend, Monica (Ellen Page). Some men may have found Monica to be irresistibly sexy, but Jack protests that he will not be one. Nevertheless, he does fall for the reference-dropping, bragging actress, and is shattered when she leaves Rome to begin filming a new movie. Hobie is dumbstruck when a drenched and drugged Melinda (Radha Mitchell) shows up unannounced in the middle of entertaining business investors with a dinner of Chilean sea bass with lime flakes. Despite her history of incarceration (for shooting her husband), Hobie is immediately smitten with her impulsive passion. Unlike Jerry and Jack, Hobie finds himself happy and in love with Melinda at the end of the film.

Passion ruptures the expectations of everyday life. Monogamous, curious, passionate, maniacal: love is the topic on everyone's lips in Vicky Cristina Barcelona. Allen contrasts the businessperson's urban American hegemony of marrying the 'right person' and creating a lifestyle of golfing, decorating, and dining with the artistic, Spanish (both Catalan and Northern 'Spanish') sensibility wherein the pain and longing of the life is continually the motivation for creative works and conversation. This creative passion does not stay with the Spanish characters, but infuses nearly every character. Rather than threatening to undo the stable boundaries of relationships, passion wakens and transforms the characters.

Vicky (Rebecca Hall) and Cristina (Scarlett Johansson) provide contrasting types of passionate love, and serve as metonyms of the fate of romantic relationships (as destined within the film). Vicky is a dark haired, rational, emotionally guarded, graduate student who distantly observes—like a 'good' ethnologist — the vibrant Catalan culture around her. Vicky's character is positioned as being destined to follow the paths of the expatriate New Yorker, Judy (Patricia Clarkson), who steals a kiss from her husband's business partner at a party, yet is "too afraid to leave her situation"; and, the couples she keeps encountering in Barcelona, who fuss over decorators for their flats in Greenwich Village and 
ways to watch television while traveling for work. Cristina, on the other hand, is an unnaturally blond, creative type who has yet to find her medium, even though she has starred in, directed, and written a 12 minute short film about "why love is so hard to define", which she detested. Cristina is 'at liberty' in Barcelona to do what she pleases. As the narrator succinctly states when first introducing them: what "Cristina doesn't want, Vicky values above all else." Vicky reveals her own disdain for passion by describing Cristina as a "romantic with a death wish" who "abandons everything for romance," but Cristina prefers to simply think of herself as being open to finding what she wants, and not resting until she gets it.

What each girl gets is a testing of boundaries: Vicky makes love to Juan Antonio (Javier Bardem) despite being betrothed to Doug (Chris Messina), and Cristina attempts polyamory with Juan Antonio and Maria Elena (Penelope Cruz). The passionate experience with Juan Antonio shook Vicky and "confused her." Though, she claimed: "I don't know what I want anymore," her comfortable life with Doug is what she ultimately chooses. Cristina moves in with Juan Antonio to help him create art, but uncovers in herself a passion for photography and Juan Antonio's ex-wife, the convalescing, Maria Elena. Cristina eventually decides to move out of Juan Antonio's home to pursue her own, separate, passion, back home in America. The heat warms up life, if only momentarily.

\section{The Cold Feet}

Sonia: "To love is to suffer. To avoid suffering one must not love. But then one suffers from not loving. Therefore, to love is to suffer; not to love is to suffer; to suffer is to suffer. To be happy is to love. To be happy, then, is to suffer, but suffering makes one unhappy. Therefore, to be happy one must love or love to suffer or suffer from too much happiness. I hope you're getting this down."

Natasha: "I never want to marry. I just want to get divorced." 
Given the attention that the cold feet receive in the rest of this work, I will be brief in my exposition here. Left timid and lacking self-confidence after a divorce (or two), the cold feet are hesitant and apprehensive, if not totally anxious, about romantic relationships. "Get a woman into bed! I couldn't get a woman into a chair," shyly complains the bumbling Allan Felix (Woody Allen) in Play It Again, Sam. Allan's comedic ways resemble that of Alvy Singer in Annie Hall, Isaac in Manhattan, and Mickey Sachs in Hannah and Her Sisters. Celestino Deleyto (2006) likewise describes Isaac as similar to Allan with his "mixture of intellectual and sexual urges" (p.29); however unlike Allan, Isaac "is very successful with women but not without personal problems (p.29). For the cold feet, loving again is a hopeless task. The cold feet shy away from women, and need coaxing from others to flirt. When Darvon and apple juice are not strong enough to mask his fear, Allan Felix relies on an imagined Bogart's ${ }^{7}$ step-by-step instructions through life. Wanting the security and certainty that the other person is as vulnerable in love as they are, the cold feet delay expressions or confirms of love until the final possible moment. For example, Alvy word plays loff and luff, and before pushing the responsibility onto Annie by asking: "Didn't you think I loved you?"

The cold feet employ the strategy of using humor to hide his anxiety about his shortcomings, or what Geoff King (2002) has described as Jewish humor, a self-deprecating form of humor that serves as a defense strategy (p.153). Indeed, the cold feet bare a resemblance in their use of humor and

\footnotetext{
${ }^{7}$ The Bogart that Allan imagines is a sort of collective Bogart. As Stanley Cavell (1981) explains, to talk about Bogart is to refer to "'the figure created in a given set of films.' His presence in those films is who he is, not merely in the sense in which a photograph of an event is that event; but in the sense that if those films did not exist, Bogart would not exist, the name 'Bogart' would not mean what it does. The figure it names is not only in our presence, we are in his, in the only sense we could ever be" (p. 28).

${ }^{8}$ For Frank Krutnik (2009), Alvy "compulsively subjects [the word love] to a string of punning disavowals and deformations that translate it into the pregnant signifiers 'loathe' and laugh"' (p. 21). This malapropism renders Alvy's anxiety around love as antagonistic, if aggressive. I read this scene as more gently expressing Alvy's anxiety as an inability to mouth or pay lip service to Annie by saying I love you.
} 
conversation strategy to the Woody Allen schlemiel (Desser and Friedman, 2004; Wernblad, 1992; Feuer, 2013), the little-man character (Pogel, 1987), or the Woodman (Spignesi, 1992). But the cold feet are not limited to these little men.

The nervousness of the cold feet affects Purple Rose of Cairo's Cecilia, the sweet cinephile who is trapped in an abusive relationship; Sleeper's (1973) Miles (Woody Allen) the health food storeowner who awakens in the future only to fight his feelings for poetess Luna (Diane Keaton); and, Love and Death's Boris (Woody Allen) who is sent off to war, but pines for his cousin Sonia (Diane Keaton). As Julian Fox (1996) points out, in Everything You Always Wanted to Know About Sex* but were afraid to ask, Allen "[managed] to transpose his own New York-based anxieties on to his 'sub-human' role as the pre-ejaculated sperm cell, all too aware of a world out there which literally bristles with unknown terrors" (p.69). The cold feet's fearfulness of love is not only based on their fear of rejection and being rejected again, but their uncertainty as to how to make a loving relationship work in a way that they can be themselves.

\section{What Is This Thing Called Love?}

In his own armchair philosopher-psychoanalyst way, it would seem that Allen is concurring with Kristeva: the psyche is optimal and most healthy when in love. As Julia Kristeva (1987) explains: "The psyche is one open system connected to another, and only under those conditions is it renewable. If it lives, your psyche is in love. If it is not in love, it is dead" (p.15). For Kristeva (1987), the love between the analyst and analysand is an "optimum form of interrelation" (p. 15) because it avoids fusion, and possesses a death stabilizing absence. However, Kristeva (1987) advocates against falling in love during the process of transference since this bond is temporary and functional, and is not intended to last. If one were to fall in love during transference, it would be because they take the self 
too seriously (Kristeva, 1987, p. 10). ${ }^{9}$ Worse still, Kristeva (1987) cautions, transference is "scandalous", "dehumanizing" and "depsychologizing." The effect of love should be renewal, and creativity.

Despite their commitment to analysis, specifically Freudian analysis, it seems not to have been the solution for the Allenesque character. ${ }^{10}$ Play it Again, Sam's Allan wanders San Francisco while his analyst is on vacation. Banana's (1971) Felding Mellish (Woody Allen) reveals he was a bed wetter who slept with an electric blanket that would shock him at night, yet analysis was unable to cure him. In a stand-up routine, Annie Hall's Alvy shares that he was seeing a strict Freudian. During a suicidal period, Alvy chose not to kill himself because he would need to pay for the sessions he would have missed. Later, Alvy tells the Hall family that he looks forward to no longer wearing the lobster bib during his visits to the analyst. While visiting his own analyst, Alvy complains that Annie is making more progress than he is. Manhattan's Mary calls her analyst Donnie, and he calls her after a bad acid trip; Isaac can only refer to his analyst as Dr. Chomsky, lest he be hit with a ruler. Hannah and Her Sister's Mickey made so little progress in analysis that, he jokes, his analyst put in a salad bar. The analyst's office, though intended to be, is not a space of transformation. ${ }^{11}$

Woody Allen's films in general highlight the problematics that arise when love is thought of as a unity made up of two imperfect or incomplete people, who come together in the perfect compliment to make a whole. This love of unity or fusion has infused a majority of philosophical discourses on love let alone popular discourses. At the root of this love is a Platonic love, not in the vernacular sense of

\footnotetext{
${ }^{9}$ To suggest that the individual take the self too seriously is to suggest that they become fixated on their sense of self at that particular moment, rather than acknowledging the need for the creative development of the sense of self and identity that brought them to analysis in the first place.

${ }^{10}$ Woody Allen's own contribution to pscyhoanalysis is noted by Alain J. Cohen (2004) who comments on how he has " illuminated psychoanalytic questions through filmic form, and we may add chiasmatically, to have infused film form with psychoanalytically distinct material" (p.128).

${ }^{11}$ It is a popular misconception that Allen is an advocate of psychoanalysis. Although Allen makes mention of psychoanalysis, his relationship to it is complex and critical.
} 
friends who love each other, but in the sense of the human who was once a round asexual being, and was later divided into two halves. ${ }^{12}$ The circular human was split in half, and sought only to reunite with their other half. Once the two halves of the human are reunited, they do not want to separate and are willing to go without food in order to remain together. Plato's dialogue on the human is an undercurrent of the popular notion of lovers completing each other- that they are each imperfect until they form a unit.

Woody Allen's films set themselves apart from Hollywood films that explore love. Hollywood films approach love reductively. The assumption that Hollywood films make and the assumption that is carried through to academic discourse is that love is implicitly understood. The taken for granted common understanding of love is evidenced by the lack of discussion of love, specifically in texts on the Hollywood romance (Todd, 2014; Mortimer, 2010; Krutnik, 1990). For example, Todd (2014) offers a single sentence borrowed from Anthony Giddens to ground her work. The issue of oversimplifying love by taking a common understanding of love for granted cannot be overstated. Romantic comedies in particular set up romance as a series of steps which are reflected in generic narrative markers: a meet-cute, boy wants girl, boy chases girl, girl refuses boy, boy gets girl narrative model (Mortimer, 2010). The kind of marriage figured in the classical and a majority of the contemporary Hollywood films is predicated on a love of unity. In the case of romantic comedy, these films must end with marriage since the goals of marriage (buying a home, producing children, contributing to the productive forces of society) are antithetical to the lighthearted goals of the romance. ${ }^{13}$ Unity through marriage was a side effect of the happy ending, but this unity—despite its

\footnotetext{
${ }^{12}$ In the Symposium, it is Aristophanes who describes this kind of love, and not Socrates or Plato. In order to maintain similarity with other texts, I will refer to this as Platonic love, even though it is perhaps more accurately termed an Aristophanesian love.

${ }^{13}$ See Frank Krutnik $(2002,2009)$ for a further discussion of the dissonant goals of romance and marriage.
} 
mythic promises - does not fulfill, and the cold feet understand this.

The cold feet express their fear of a love of unity. Alvy overtly indicates his dread of unity when Annie brings over boxes of her stuff to his apartment and he hesitates: "you don't want it to be like we're married do you?" Rightly, Annie answers: what's the difference? Annie is already committed to Alvy, spends her time at his apartment, and would prefer to have her things close by. Alvy's response arrives quickly: no matter how expensive Annie's apartment is, whether it has bad plumbing or bugs, it is a life raft. Alvy equates her apartment to a life raft that preserves their separation. The apartment indicates that they are not married and that "they", as individuals cannot die, but are buoyed up by boundaries. Despite Yacowar's (1979) and Lee's (1997; 2013) readings of Alvy as a Pygmalion figure who changes Annie, it is Alvy who worries about being changed in love and losing what makes him distinct.

United by their nervous apprehension, Allan, Alvy, Cecilia and Mickey will be referred to as the nervous romantics. ${ }^{14}$ Marriage, for Alvy, brings death, the death of his individuality in the form of unity. But, marriage is not the only expression of love, and unity is not the only form of love. Allan does not believe that women would be interested in him. Cecilia is trapped in her relationship with Munk, and does not see love beyond the horizon of his shackles. Mickey is fixated on finding out the meaning of life, and needs external validation. They seek external confirmation that they are worthy of love and are loved by someone. To be seeking the security of validation through love is to be caught up in the belief that they are imperfect. This belief presumes that love only proceeds through unity. What the cold feet realize in the final moments of the narrative is the potential for a love that is otherwise: a love of non-fusion.

\footnotetext{
${ }^{14}$ The term Allenesque character refers only to the characters played by Allen himself: Allan, Boris, Alvy, Sheldon, Isaac, and Mickey. Whereas the nervous romantics include: Allan, Alvy, Cecilia, and Mickey, the exemplars who are the focus of this work.
} 


\section{Loving Otherwise}

A change of heart does occur for the cold feet. Allan comes to have a brief, but successful interlude with Linda, and realizes that he cannot stand in the way of Dick and Linda's relationship. Being romanced by a screen star enables Cecilia to realize that there is nothing to prevent her from experiencing love. Cecilia gains the courage to leave her abusive and deceitful husband, and make it on her own. There are two 'miracles' for Mickey: he is neither suicidal, nor sterile. Alvy's half-hearted proposal of marriage, which Annie laughingly declined, became creative fodder and was rewritten as a script for his first play. When given the chance to spend time with Annie, Alvy realizes it was a pleasure just knowing her. What is initially not clear to the cold feet is that a different kind of love is possible, a love of letting be is an alternative. Finding faith in others, realizing we need the eggs, and a beautiful friendship are non-reciprocal forms of love that recognize differences between lovers and that each lover is a whole person. The cold feet's realization and initiation into a love predicated on wholeness and letting be is the focus of the next two chapters. A brief sketch of a love of letting be here will serve to anchor the proceeding discussion of the phenomenological method which informs the experience of the cinematic other as relating to the experience of the lover.

A love of letting be assumes a relationship between two whole beings, and is grounded in their embodied experience. A love of letting be begins from a phenomenological encounter of the other, the other who is always in excess of our understanding and comes to us through our intuition. A love of letting be is not a kind of reaction, an affect or something psychological; "[love] does not have to do with an emotion or passion, or even less with a delirium, but first of all with what phenomenology calls a lived experience of consciousness" (Marion, 2007, p. 95). Love "[falls] under an erotic rationality" (Marion 2007, p. 5). The experience of the body is central to developing a loving relation. Irigaray (2001) notes that the West has no culture of cultivating bodily experience, and this has a direct impact 
on the cultural positioning of love: "The fact that loving relations are, for the most part, considered a sort of decadence seems to come from a tradition of the sensible which has no respect for intersubjectivity or the exchange of words between those who love each other" (p. 23). Irigaray (2001) goes on to explain that "[o]ur spiritual senses are not trained to love" (p. 42). Since for Irigaray we lack a culture of perception, this implies that we lack a culture that has intersubjective relationships, and thus as a consequence we lack a culture of love. ${ }^{15}$ Clearly and directly, Irigaray (2001) argues: "a cultivation of perception would modify our loving relationships" (p. 23). The cultivation of perception and auto-affection would bring about a love of letting be.

A love of unity is a form of economy, where each partner must reciprocate. A love of letting be does not assume reciprocity, but simply loves, even at a loss. To speak of love in economic terms is to speak of loss and gain. But the lover only gains, as love is akin to a gift. As Jean-Luc Marion (2007) explains "The lover has the unmatched privilege of losing nothing, even if he happens to find himself unloved, because a love scorned remains a love perfectly accomplished, just as a gift refused remains a perfectly given gift" (p.71). Love is never lost or unrequited love is not a loss, but remains as love. "Thus it is necessary to reject reciprocity in love, not because it would seem improper, but because in love reciprocity becomes impossible--strictly speaking, without an object. Reciprocity sets the condition of possibility for exchange, but it also attests to the condition of love's impossibility" (Marion, 2007, p. 70). Similarly for Irigaray (2001) desiring does not take us out of our own experience, nor does it blind us to the experience of the lover. Rather, desire "becomes a double intention which animates me: I want to return to myself, in myself, and I want to be with you" (Irigaray, 2001, p. 26). Lover and lover "always remain active and passive, perceiving and

${ }^{15}$ Irigaray's critique of the lack of perception is based on her observations of patriarchal culture which upholds values of rationality and logic, and which ignores the sensations and affects of the body. This will be further developed in later chapters 
experiencing, awake and welcoming. In us, sensible nature and the spirit become in-stance by remaining within their own singularity and grow through the risk of an exchange with what is irreducible to oneself" (Irigaray, 2001, p. 27). The rejection of reciprocity in love permits a fluidity of sharing between lovers.

A love of letting be does not impose a horizon on the lover, or make assumptions about who they are. Letting be "presupposes that we renounce imperatives born from the subjection of the one to the other: a making of beauty or a making of erection, for example" (Irigaray, 2002, p. 117). Alvy fears the disappearance of his uniqueness, Cecilia is too afraid to express herself or be independent due to Munk's bullying, and Mickey subsumes his creativity to an industry which uses fake laughter: they find themselves in situations where they are imposed upon. In a love of letting be "[o]ne must love enough to generate and not wound: love the other as a whole, love him in his life without giving him one's own" (Irigaray, 2001, p. 12). Irigaray (2001) sums up the assumption of a love of letting be, when she asks: "Does existing not mean offering you an opportunity to become yourself?" (p. 15). To let be is to support and allow the other to develop into themselves, while we develop into ourselves.

The effect of love is health and growth, and the effect of false love is demise and decay. While this offers us an insight into the result of love, it does not explain what love is, nor does it explain how to relate to the beloved. Many questions are still left unanswered: how is love accessed? How is it practiced? Love and Death's Boris claims that sex like death happens only once a lifetime, and at least after death you're not nauseous. Does love occur just once, and do we have to wait in line? To answer these questions, this work offers one way of considering these aporia while acknowledging that this problem is not individual, but cultural. The cold feet's own transition offers a way of relating to the lover as a genuinely uniquely other. The following chapters will gesture toward a renewal and 
enlightenment through love. This begins by encountering the nervous cold feet at the crux of their confusion between longing for love, and fearing love. 


\section{Chapter 3: \\ Going to the Cinema with Woody Allen}

In the previous chapter Woody Allen's films were analyzed and categorized to reveal the varieties of relationships that are represented. The cold feet of Allan, Alvy and Mickey, and the sweet Cecilia are exemplary characters who have experiences in the cinema that transform them in their loving relationships. This chapter endeavours to inquire into the phenomenological experience of the cinema, and the cinematic other.

\section{A Reality Check: You Were Always Outta Step With The World}

Examining the types of romantic relationships at work in Allen's films revealed that the prescription of his work as dualist between optimism and pessimism was too narrow. Still another dualism that needs to be brought to the open is the divide between fantasy and reality. Critics, commentators, and biographers writing on Allen often comment on the bleeding between reality and fantasy in his films (Bailey, 2001; Cowie, 1996; Detmer, 2004; Singer, 1998). This confusion extends to the Allenesque character resembling Allen himself (Pogel, 1987; Girgus, 2002; Lax \& Allen, 2009). Girgus (2002), for example, claims that Allen exploits this in Play it Again, Sam where even the "similarity of names becomes a joke" (p. 13). The confusion between Allan (Felix) and (Woody) Allen intentionally complicates; "He uses the distinction between himself as interior character and external personality and director to introduce psychological, thematic, and artistic complexity into his subjects, characterizations, and narratives" (p. 13). Likewise in Annie Hall both Woody and Alvy are comedians. The merging of fantasy and reality is most exemplary in Allen's use of cinematic devices or "visual inventions" (Cowie, 1996) or "antimimetic emblems" (Bailey, 2001, p. 36). Cinematic devices such as the use of split-screen, re-ordering chronology, the use of animation among others are typically understood as forms of abandonment of reality.

The reality avoided is one that is too bizarre or too horrible, if not totally miserable to face. To 
consider the cinematic devices as simply fantasy overlooks and forgets one key attribute of the Allenesque character: their use of embellishment, exaggeration and superlative language as mode of humor and a dramatization. Peter J. Bailey (2001) allows that these meta-cinematic devices are "indistinguishable from jokes" (p. 35). However, for Bailey (2001), these devices affirm a flight from reality, and do so humorously. For Bailey (2001), these devices lay the charges against the Allenesque characters, like the charge Alvy's mother makes about him: "you never could get along with anyone at school. You were always outta step with the world" (p. 36). But whose world is the Allenesque character out of step with? The Allenesque character is firmly rooted in the Allenesque world.

The Allenesque character is a jokey-nervous type, who is prone to exaggeration —as a result of their anxiety — and relies on their humor to make themselves comfortable in the world. The severity of exaggeration reflects the fears of the character, as expressed through the use cinematic devices. Oepidus Wrecks' Sheldon Mills frets over his mother's loose lips that blab his business all over New York. When she appears in the Manhattan sky after an accident in a dematerializing magic trick, she literally does tell everyone in the city embarrassing stories about Sheldon. In Stardust Memories, the wallpaper of Sandy Bates' apartment becomes more violently graphic as the domestic situation with his hired help becomes more peculiar and frustrating. These slips of fantasy or whatever we might call them are not ways to disqualify the character's experience as somehow less than what we might take to be their 'real' experiences, or moments of escape from reality. Rather, they are the inner experience of the character shown to us via the specificity of the filmic medium. To momentarily borrow the language of film studies, Allen dramatizes, perhaps better, cinematizes the experience of everyday life in a way that is not possible in real life, but only in reel life. Allen's cinematization of experience, replete with the affective and internal, is akin to a cinematic thinking.

For example, in Annie Hall, cinematic devices illustrate Alvy's mutual displacement from both 
his own family and the Hall family. The use of split-screen juxtaposes the families, while the shot of Grammie Hall imagining Alvy dressed like a Hassidic Jew reveals Alvy's own worries over her antiSemitism. For Sander Lee (1997), this scene "undermines Alvy's assumptions at the dinner table about who the Halls are and what they are feeling" (p. 68). However, what Lee ignores is that rather than offering a definitive impression of the Halls, this scene reveals Alvy's paranoia about how others see him. Perhaps despite the tennis lessons and genteel (gentile?) manners, Alvy is more like the "real Jew" Grammie Hall imagines him to be, than he wants to let on. Foster Hirsch (1990) offers a rather convincing reading of the "sex-obsessed, witty, ironic, irreverent, plagued with ego problems, and struggling to find a place for himself" Allenesque character as akin to the characters in the "modern Jewish novel of manners" (p. 140) written by Saul Bellow and Philip Roth. For Hirsch (1990), at the heart of Allen's romantic narratives "the on going battle of the sexes-is dramatized as a conflict between Jew and gentile" (p. 141). Lawrence J. Epstein (2001) concurs, arguing that "In Allen's films romantic love stands in opposition to Judaism, which is identified with stifling family life and repressed sexuality, and to Jews who are outsiders to the more serene world of WASP emotional calm and beauty. Indeed, Annie Hall and Manhattan turn WASP women into more than attractive sexual partners. They become the metaphor for acceptance" (p. 204). This metaphor of acceptance is illustrated through the use of cinematic devices. In these instances, cinematic devices reveal the Allenesque character's worry about fitting in and the way they have divided up the world into groups and types of people. Their worry over fitting in is exaggerated by their assumption that there is not a social group for them, and worse still, they would not allow themselves membership into any regardless.

Due to their own internalized struggle, the Allenesque character seeks out acceptance. "The fear of marrying [their mother] sends the Jewish sons of the world into their fevered search for the perfect 
shiksa, girl who will not berate, cajole, henpeck, or emote, who will not above all, instill guilt or fan the flames of anxiety, but who will put out and let him be" (Hirsch, 1990, p.141). When understood from Hirsch's vantage, the literally magical disappearance of Sheldon's (Woody Allen) mother is a dream come true to allow him to marry an ideal shiksa, Lisa (Mia Farrow) who adores him. Sheldon's initial attempt to distance himself from his Jewish heritage is evident in his name change from Millstein to Mills. ${ }^{16}$ Oedipus Wrecks, of course, ends with Sheldon falling for Treva (Julie Kavner), the kooky psychic-cum-nice Jewish girl, who wraps him up some boiled chicken in foil for a snack, with a heart after his own mother. In his own way, Sheldon comes to a comfortable negotiation with his Jewishness. However, Oedipus Wreck's ending does not discount the tensions felt for the other characters as they attempt to negotiate cultural codes. Alvy's shock when Annie orders pastrami on white bread, with mayonnaise, tomato, and lettuce, makes it clear that these cultural codes work both ways. Certainly, Allen's comedies are as much comedies of manners, comedies of ethnic manners perhaps, as they are romantic comedies. The cinematic devices, therefore, do not 'stop' the narrative, but on the contrary, they enrich the narrative and suggest how deeply enmeshed the cinema and cinematic form are to the Allenesque character in their articulation of their identity and their personal narrative. ${ }^{17}$

\footnotetext{
${ }^{16}$ The Golden Book of Jewish Humor (1972) includes a well known Jewish joke about the Oedipus complex:

"Mrs. Yifnik," said the psychiatrist, "there is nothing physically wrong with your little boy. But I must tell you this: He has an Oedipus complex."

"Oedipus-shmedipus!" snorted Mrs. Yifnik. "Just so long as he loves his mother."

${ }^{17}$ It should be noted, and mentioned again, that Allen's work evolved along with his artistry. While Allen is often the director, writer, and star of his films, his films benefited from their crew, in particular the cinematographers who Allen admits were influential in the developing the complexity of the films (see Lax and Allen, 2009). Allen worked with Gordon Willis on Annie Hall, Interiors, Manhattan, Stardust Memories, A Midsummer Night's Sex Comedy, Zelig, Broadway Danny Rose, and The Purple Rose of Cairo. Willis is well known for his work on Klute (1971), The Godfather Parts II (1974) and III (1990). Sven Nykvist, who worked with Ingmar Bergman on several films including The Virgin Spring (1960), Cries and Whispers (1972), Face to Face (1976) and Louis Malle on Black Moon (1975) and
} 


\section{A Double-Movement of Cinematic Thinking}

Just as nervousness is central to the Allenesque character, so is the cinema. Since the cinema is at the center of the world for the Allenesque character we enter into a world not only in the cinema, but of the cinema. There is a kind of double-movement of cinematic-thinking at work. Through the prism of cinematic-thinking, a cinephile is theorizing about a cinephile's encounter in the cinema via cinematic-thinking. This double-movement is essential to consider since rather than reflecting on personal experience, the focus of theorization is externalized, brought outside the writer, and remains localized in the cinema, in the content of film. Drawing upon the cinematic imaginary in films such as Play it Again, Sam, The Purple Rose of Cairo, Annie Hall, Hannah and Her Sisters, Stardust Memories illustrates the inner workings of the protagonists who are cinephiles.

A cinephile in its simplest understanding implies a person who loves the cinema. The cinephile has a particular mode of living in the world, and loving the world through the cinema. The cinema is so important to them, so central to their identity, that to ignore the influence of the cinema in their lives is to ignore an important aspect of who they are. Further, like any lover, the cinephile must consider whether they have a relation of mastery, or of letting be.

In order to understand the world of these cinephiles, it is first necessary to sketch out a method of approaching and interacting with the cinema. Contra to theoretical approaches that assume movie-

Pretty Baby (1978), worked with Allen on Oedipus Wrecks, Crimes and Misdemeanours (1989), Celebrity (1998). Carlo di Palma, who was also Michaelangelo Antonioni's cinematographer for Red Desert (1964) and Blow Up (1966), worked with Allen on Hannah and Her Sisters, Radio Days, September, Alice, Shadows and Fog, Husbands and Wives, Manhattan Murder Mystery, Bullets Over Broadway, Don't Drink the Water, Mighty Aphrodite, Everyone Says I Love You, and Deconstructing Harry. Where Play it Again, Sam relies on visual gags and jokes in the narrative, later films such as Hannah and her Sisters creatively use sound and space. For example, when Elliot takes Lee to the bookshop, the camera mimic Elliot's chase of Lee as it pans right and left through the bookshop aisles revealing rows and rows of musty, dusty books, even though the two are off screen somewhere, their voices are clearly audible. The cinematic devices and cinematic thinking within Allen's film develop in their nuance and complexity throughout his career, and are often influenced by his directors of photography. 
going as a passive activity that is primarily visual, cinematic spectatorship will be approached as an active activity that stimulates both cognitive and body perception. In order to differentiate between the passive and active spectator, the term cinephile will be used to emphasize the embodied relationship with the cinema, and to anticipate the discussion of love that arises in later chapters. A phenomenological film-philosophy approach will be used in order to focus on the embodied and intersubjective relationship between the cinema and cinephile. The intersubjective relationship between cinephile and cinema assumes that the cinephile approaches the cinema as an other ${ }^{1819}$; this foregrounds the relationship between lovers, which is expounded in phenomenological terms in later chapters. Once the cinematic relationship is clarified, it is followed by a filmic analysis, a close embodied reading, of the cinematic world of the nervous romantic. Again, this work is characterized by a double cinematic thinking: it is the analysis of a cinephile by a cinephile. Further, the work undertaken here anticipates how the cinephile encounters and considers the cinema.

The nervous romantic finds solace from their neurosis in the cinema, and opens themselves to

${ }^{18}$ The other is a term that is used throughout many academic disciplines, and often appears capitalized as Other or the Other. Each of these uses bring forth a specific connotation of how to regard another person. Given the philosophical context here, it is necessary to distinguish between the Hegelian and Sartrean use of the Other, and the Other as used by Levinas, Irigaray and Marion use of other. While the Other of Hegel and Sartre is understood to pose to a threat, and their knowability must be assimilated into our understanding, for Levinas, the Other is understood as an engima whose presence and mystery must be protected. As Simon Critchley swiftly summarizes "Levinas' one big thing is expressed in his thesis that ethics is first philosophy, where ethics is understood as a relation of infinite responsibility to the other person" $(2002$, p.6). The subject is given its subjectivity through its relation to the Other. Where the Other is "not a phenomenon but an engima, something ultimately refractory to intentionality and opaque to understanding" (Critchley, 2002, p.8). Since, for Levinas, the subject always has a prior commitment of infinite responsibility to the Other, ethics comes before ontology. Rather than posing a threat, the encounter with the other asks us to question both of our vulnerabilities and to respond with a sense of ethics. Thus, the relationship to the other is always asymmetrical. The use of the term other is still further complicated by Vivian Sobchack's reference to an agential Other. Sobchack corroborates the appeal to an unknowable other who must not be controlled or dominated.

${ }^{19}$ Since this work draws part of its theoretical grounding from the phenomenological work of Luce Irigaray, I will remain consistent with her use of the lowercase o in other. Where a capital letter is used, it is to remain consistent with the author that I am referring to. 
fully experiencing the cinematic encounter. However, the experience in the cinema has yet to illuminate the nervous romantic's extra-cinematic experiences of love. A phenomenological analysis of the nervous romantic's encounter, which is itself a phenomenology, permits attending to the immediate and embodied responses of a loving encounter in the cinema. The implication being that in order to understand love in the cinema of Woody Allen, we must love in the cinema with Woody Allen.

\section{Practicing Film Phenomenology}

First, it is necessary to attune ourselves to the cinema. Maurice Merleau-Ponty's phenomenology of the body that emphasizes the role of perception ${ }^{20}$ is a touch stone for Vivian Sobchack's $(1992,2004,2008,2011)$ instructive intersubjective film phenomenology and practice. Sobchack's work, in turn, influenced Tarja Laine's (2011) work on recollecting cinematic emotion, a mode of embodied close reading, and Daniel Frampton's (2006) radical mode of film-philosophy, filmosophy. Merleau-Ponty, Sobchack, Laine, and Frampton are the foundation of the approach used here. All of these theorists emphasize film as an agent with its distinct internal process to think, feel, and direct the audience's attention. An intersubjective approach allows for a consideration of the film as an other. Such an approach literally repositions the question of cinephilia and viewing as a relationship not simply to the screen but with the screen. In this way, in later chapters, we will begin to inquire into the relationship between the cinephile and other, as if an analog between two lovers.

Attention to embodied experience and perception is a core aspect of the relationship with the cinema. Maurice Merleau-Ponty (1964) emphasizes the role of perception in the cinematic experience: "Perception permits us to understand the meaning of the cinema. A movie is not thought; it is perceived"(p. 58). The entire body, not simply the mind, is involved in experiencing and gathering

\footnotetext{
${ }^{20}$ Sobchack (1992) describes perception for Merleau-Ponty as the "bodily access or agency for beingin-the-world, for having both a world and being. Perception is the bodily perspective or situation from which the world is present to us and constituted in an always particular and biased meaning" (p.40)
} 
meaning from film. Sobchack (2004) goes on to explain "To understand movies figuratively, we must make literal sense of them [my emphasis]" (p. 58). Filmgoers, Sobchack (2008) emphasizes in a later article "have always made sense of the cinema (and everything else) not only with their eyes, but with their entire bodies" (p. 194). The body and mind, as Elizabeth Grosz (1994) describes, function as a moebius strip, feeding into one another. Not to be undervalued, "bodies have all the explanatory power of minds" (Grosz, 1994, p.1), and movies "are particularly suited to make manifest the union of mind and body, mind and world, and the expression of one in the other" (Merleau-Ponty, 1964, p. 58).

Feeling our own embodiment is the first step in such a process, the second involves recognizing the body and the embodiment of the film. In Laine's study of cinematic emotions, she chooses the term emotion as an umbrella term that is made up of both affective appraisals that are situational, and emotional evaluations that are contextual. Laine (2011) describes this as a "'with-ness' in the midst of the world" (p. 2). Positioned as with-ness not only recognizes, but also emphasizes the "agential participation in the cinematic experience as an emotional event" (Laine, 2011, p.4). As a with-ness in a world, not as a witness to a world, our understanding of film shifts from questioning the logic of the divide between the fantasy and reality, to experiencing the agency of the film. As a with-ness in an Allenesque world participation is serious, seriously humorous.

We are with-ness to the world of the film body that reveals its reality, the film mind that structures, and the film heart that emotes. Laine (2011) and Frampton (2006) are indebted to Sobchack's groundbreaking work that establishes film as an intentional agent with a film body. Recognizing film as a body allows for an interpretation of the cinematic experience as occurring between two beings. As Daniel Frampton (2006) explains "What is important about Sobchack's move to seeing film as a body is the way that it allows for social meaning-allows for a historical, situated film: a body that intends" (p. 43). This recalls Merleau-Ponty's expression of cinematic spectatorship as 
establishing a dual-being; cinephilia is a shared experience of a world.

\section{A Relation Between Two}

The intention of this section is to establish the intersubjective relationship between two: the cinephile and the cinema. Utilizing the anthropomorphic language of the body (Sobchack, 1992, 2004, 2008, 2011; Frampton, 2006; Laine, 2011), and then later mind (Frampton, 2006; Laine, 2011) and heart (Laine, 2011), may confuse the intention of film-phenomenology. The intention is not to conceptualize film in human terms, which then limits the functionality of film by relegating it to the human. Instead, anthropomorphic language is used to demonstrate the analog of body to the world or reality, and film to world or reality. As Frampton (2006) explains "Film is not a reproduction of reality, it is its own with its own intentions and creativities. Cinema is the projection, screening, showing, of thoughts of the real" (p. 5). So, in same way that phenomenology approaches the body as situated within the world, too film phenomenology understands film as situated within a world. The adoption of the terms film-body, film-mind, and film-heart are useful here only insofar as they offer ways of discussing attributes of the cinema. More importantly, such an approach grants the cinema otherness. Recognizing the film as a body within a world maintains the film as an other, and realizes the intersubjective relationship between (human) body and (filmic) body.

What Frampton (2006) refers to as the film-body is not reducible to the perception and expression of the filmmaker through the medium, rather it is a being. As Sobchack (1992) notes: "The film experience not only represents and reflects upon the prior direct perceptual experience of the

filmmaker by means of the modes and structures of direct and reflective perceptual experience, but also presents the direct and reflective experience of a perceptual and expressive existence as the film" (p.12). Sobchack (2011) later modified her explanation of the film's body, explaining that it is not visible in the film except for its intentional agency and diacritical motion. It is not 
anthropomorphic, but it is also not reducible to the cinematic apparatus (in the same way that we are not reducible to our material physiognomy); it is discovered and located only reflexively as a quasi-subjective and embodied "eye" that has a discrete-if ordinarily prepersonal and anonymous-existence. (p. 48)

In watching a film, our horizon becomes fused with the film body, in a "series of mediated exchanges between our bodies and the film's body" (Sobchack, 2008, p.195). Thus, "the film experience entails at least two viewers viewing (film and spectator) in a dynamic relational structure" (Sobchack, 2011, p. 192). Sobchack's notion of the film's body has been adapted by Frampton and Laine, and for all theorists the film's body remains as a participant in the intersubjective relationship.

Where Sobchack's work emphasizes the film's body as the other that is related to, Frampton's (2006) filmosophy considers a film-mind, the filmic world of the narrative and characters, and filmthinking, the "action of the film form that dramatizes" (p.7). As previously mentioned, Frampton (2006) emphasizes the distinction between human and film thinking. "The way in which film 'thinks' does not phenomenologically mirror the way our consciousness audio-visually thinks" (Frampton, 2006, p. 47). Further, understanding film-thinking anthropomorphically is problematic because it limits film-thinking and would suggest that we would then only "find human-like styles in film form" (Frampton, 2006, p. 42). Frampton's (2006) filmosophy understands the meeting between human and cinema as a "mix of minds rather than bodies" (p.160); for him the bodily experience is secondary, "the filmgoer's body dies, and the mind fully takes over" (2006, p. 160). At the point of a tête-à-tête, Frampton and I part ways. What I take away from Frampton's work is the necessity of offering the cinema its own phenomenology that is understood on its own terms in its own gestures, rhythms, and language, rather than mapping human criteria to film. However, I maintain, following Sobchack, that the encounter between two bodies is felt and negotiated through the body.

In a way, Frampton anticipates The Purple Rose of Cairo's Tom Baxter (Jeff Daniels), the explorer who walks off the screen to explore love with Cecilia, confusing cinematic-thinking and 
human thinking. Frampton (2006) states, "When I am in love with someone they do not always appear to me in soft-focus" (p. 47) or when we kiss the lights do not automatically fade out. ${ }^{21}$ The verisimilitude or "similarity" (2006, p. 47) between cinematic thinking and human thinking for Frampton is functional, not phenomenological: "film enacts its own version of franticness and paranoia" (2006, p. 47) and other affective states. The differentiation between film-thinking and phenomenology will become increasingly important in order to understand on-screen relationships between and among characters, and the spectators or cinephile's relationship with the screen. Like Frampton's (2006) filmgoer, the nervous romantic as a cinephile, experiences a "phenomenological 'mix' of thinkings: the film and filmgoer join in thought, and the process of that encounter provides immediate, meaning and knowledge" (p.149); however, the encounter is 'thought' or perceived through the body.

To Frampton's work, Laine (2011) adds a film-heart that has an "emotional intentionality — the 'aboutness' and 'towardness' of emotion"' (p. 3). The film-thinking of Oedipus Wrecks considers the tense relationship between mother and son, while at its heart, the film moves from resentment to reconciliation. Though the spectator may laugh, Sheldon certainly fails to see the humor in his situation - which exemplifies the distinction between the film's emotional core and the experience of the spectator. In Stardust Memories, the film thinks through Sandy's past, present, and future through his relationship with three women (Dorrie, Daisy, Isobel) and his fans, but at its emotional core, the film is wrought with frustration over competing emotions: overwhelm, exhaustion, desire, nostalgia, and longing.

Such an approach asks us to re-think filmic identification. We seek not to recognize, as Sobchack (2008) clarifies "subject positions or characters, but rather to our primary engagement with

${ }^{21}$ After kissing Cecilia, Tom asks why the lights don't fade. When he discovers that people make love with a 'fade out,' he responds "Well, I can't wait to see this!" 
the sense and sensibility of materiality itself" (p.65). I do not momentarily identify with, align with, or become Allan, Alvy, Sandy or Mickey, or not even Cecilia, Marion, Alice, Melinda or Melinda, or Sally, but I register intensities in relation to watching them on-screen. My body relates to the filmic body; my body relates to the things that matter, to the things with matter.

Film phenomenology offers a way of understanding cinema as an other with whom we have a loving relationship. In later chapters, Jean-Luc Marion's erotic reduction and loving intentionality offers a method of accessing a relationship with the other. Luce Irigaray offers a way of understanding our loving relationship with this other as protected by a cultivated sensory relationship that preserves space and silence. Cultivating a sensory relationship is the route to a love of letting be. The perceptual relationship introduced by Merleau-Ponty, and then expounded upon by Sobchack, as a relation with the screen, will be the site of practice that I will use in order to express the way to cultivate a love of letting be. In the same way in which for Merleau-Ponty we must rediscover the world in which we live and are always forgetting, we must rediscover the mode of love we are always forgetting.

Understanding how to access this intentionality and perceptual relationship is the transformation necessary for the sweet and the cold feet of the nervous romantic.

Several of Allen's characters undergo transformations that change their relationship with the person they love and their attitude toward love. The most exemplary changes occur for the cold feet of Allan, Alvy, and Mickey, and the sweet Cecilia. Where Allan, Alvy, and Mickey have had their spirits crushed by divorce, Cecilia struggles keeping her spirits up daily as Munk slowly wears her down. These four are united in their apprehension of love and their transformations, that occur in the cinema, which lead them to reconsider love. The last few moments of Play it Again, Sam, Annie Hall, Manhattan, and The Purple Rose of Cairo reveal transformed characters. It is only Hannah and Her 
Sisters that allows a glimpse into the life of the transformed Mickey, who ends up in love and expecting a child.

\section{Four Exemplary Cinephiles}

The intention of the following analysis is to introduce the nervous romantics who will come to form the basis of the analysis undertaken in this work. Despite their sensitivity as cinephiles, they are out of tune with people. Understanding the frustrations and anxieties of the nervous romantic will inform their later transformation.

\section{Allan: I Can't Get a Girl into a Chair}

Play It Again, Sam opens in the darkness of the theatre where Allan's story of lost love and love found begins. The camera cuts between close-ups of Ilsa (Ingrid Bergman) and Rick in the culmination of their affair, and Allan's face twitching and wriggling; all three of their faces are equal in size, for in this story, they are all stars. ${ }^{22}$ Allan observes, instinctively shaking his head, as Bogart sacrifices his love for Ilsa. When the lights come on and the theatre begins to empty out, Allan is motionless, seated with a dumbfounded look on his face. Slowly, Allan ambles out of the theatre, fretfully talking to himself, "Who am I kidding. I'm not like that. Never was, never will be. It's strictly the movies." What strictly belongs to the movies and in the movies is precisely what Allan and these exemplary cinephiles all question. The overwhelming emotional experience in the cinema may not yet mean anything for Allan, but soon its resonance will long be felt.

Casablanca provides a blue print for Allan. Allan mistakenly believes that the leading man must exude certain qualities. Bogart is a synecdoche of the leading man with poise, confidence, fierce

${ }^{22}$ Sam Girgus (2002) takes a post-structural reading of Play it Again, Sam. The cinema and Allan's spectatorship sets up "complex analogies between the formation of both the subject in language and the spectator in cinema to the construction of gender in society" (p. 12). In this opening scene, for Girgus (2002), "we witness the semiotic invention of identity and reality" (p. 13). 
independence, and emotional impenetrability. What Allan eventually learns is that hoping that he is worthy of a woman's love assumes a place of fear, of needing reassurance. This false belief is later replaced with the awareness that not only is he worthy of love, but also he is capable of love without needing to possess the woman he loves. In the process of discovering love, Allan uncovers a love of letting be.

This screening of Casablanca is not Allan's first, nor is it his first encounter with Bogart. Allan is a writer for Film Weekly, who loves and lives cinema. Like the cinephile Susan Sontag (1996) describes, his "taste in films [is] grounded in a vast appetite for seeing and re-seeing as much as possible of cinema's glorious past." His passion for film is evident in his interior decorating - the key to which, he informs a disinterested date, is to look like you don't decorate. A reel to reel projector sits in the corner of his living room, a screen is mounted and pulled down, film canisters are stacked in piles on coffee tables and bookshelves, posters of Bogart's films cover the walls, and any remaining white space is hidden by black and white glossies of film still and head shots. A poster of Across the Pacific (1942), wider than his bed, adorns the bedroom wall.

Bogart, is not just an enlarged image, but has a real role in Allan's life as a kind of confidant and coach. Robert Sinnerbrink (2010) observes: "As any filmgoer will attest ... We can be haunted by images from films seen many years past; some images, scenes, or characters can become more familiar and significant to us than other people or even one's own memories" [my emphasis] (p. 104). Bogart haunts Allan's life in form of an imaginary friend. Allan's intimate knowledge of Humphrey Bogart's roles has given him fodder to create an imaginary friend. Allan uses his cinematic knowledge to create a friend out of his screen idol, Bogart, in order to soothe himself during his panics and help bolster his courage.

Unlike the other films, there are fewer cinematic devices used in Play it Again, Sam. Flashbacks 
and cuts to imagined sequences are the two primary cinematic devices that reveal Allan's thinking as the film's thinking. In addition, Allan's imagination is visible through the presences of Bogart and Nancy. Bogart's and Nancy's presence, flashbacks, and imagined sequences all suggest that even though he feels little control in his life, Allan is in control of the narrative.

To be clear, there was a real life Nancy that Allan was married to, and sometimes an imagined Nancy appears to reinforce Allan's worries. Perhaps instead of the angel and the devil that appear on the shoulders of cartoons, whispering encouragement, Allan struggles between listening to Bogart who encourages him and Nancy who discourages him. The two even pop up in the supermarket to quibble about Allan's potential to be sexy.

Allan, as typical of the nervous romantic, has just been left by his wife. We learn about Nancy through Allan's flashbacks, and sequences in which he imagines her post-divorce life. Nancy understood Allan as passive; as someone who likes to "space out" a lot; as a dreamer; and comments, "You like movies because you're one of life's great watchers." Nancy can no longer stand the marriage, he's no fun, she "doesn't dig [him] physically," she then nonchalantly adds, "oh God, Allan, don't take it personal." But, the pun-y, puny Allan Felix, who is a writer, is careful with his own words and takes Nancy's words to heart.

Convinced that insufficient laughter was her grounds for divorce, Allan envisions Nancy living out her laughs and adventures in ways totally outside of his comfort zone. Allan imagines Nancy riding through hilly scenery on the back of a motorcycle, being driven by a blond wearing a fringed leather vest, and not a helmet in sight. Nancy ridicules Allan for falling off a scooter, and not even a motorized one.

Allan's ego has taken a blow, and he can't quite work up the courage to be with women. He quips, "Into bed? I can't even get a girl into a chair." As Allan encounters new challenges in life that a 
Darvon and apple juice cannot fix, he uses the familiar, in this case Bogart, as a touchstone to support himself through unknown and uncomfortable terrain: particularly, opening himself up to women. Allan divulges his lady problems to Bogart, who soothes him with one-liners such as "nothing a little bourbon and soda couldn't fix" and "I've never met a woman who didn't understand a slap in the mouth or a slug from a 45." When Allan attempts to wash away his pains with a little bourbon and soda, his inner nebbish is revealed. After sipping the drink, he spits it across the bar, slams his fists, circles his head around, and finally, collapses on the table. Despite his weak constitution, Allan identifies with Bogart because he is "short and kinda ugly." "You know who is not insecure?" Allan tells Linda, the wife of his best friend, Dick (Tony Roberts), "Bogart." Sweetly and tenderly, Linda replies, "But, Allan, that's not real life." Shrugging, he replies, "I need to compare myself to someone. Who am I supposed to pick? My rabbi?" Linda does her best to convince him that comparisons are unnecessary, "you don't have to pick anyone, you're you."

Allan's struggles with women are not limited to keeping the passion alive with Nancy, even though he questions if she faked it that time two years ago. Allan is perplexed as to how his analyst could suggest that he has a sexual problem when he and Nancy were not even having relations. In consulting his little black book to locate an old paramour, Marilyn Perry, a spontaneous phone call reveals that the woman's mother was given explicit instructions never to reveal her daughters whereabouts, ever, not even after 11 years had passed. As a further example, when Dick and Linda try to set up Allan up with a model friend of Linda's, Allan's nervousness and anxiety intensifies, so much that he accidently swings an album, setting the record flying in one direction, then tosses the album cover in the other, and finally leans on a chair which falls down backward, sending him to the floor in a tumble. When in the presence of a woman whose attention he wants, Allan begins to "act" or "puts on a false mask" as Linda calls it, or quite simply, is overcome by a bewildering expression of nervousness. 
The presence and receptiveness that Allan is capable of in the cinema, evades him in his relationship with women.

Allan even misreads signals from Jennifer (Viva), a nymphomaniac, who attends Linda's group therapy. Jennifer tells Allan that she believes "in having sex as often, as intensely, as freely as possible." But when Allan attempts to kiss her, she recoils and yells, "what do you take me for?" A rebuffed Allan leaves, wondering "how did I misread the signs?"

Without becoming too prescriptive, Allan Felix's discomfort with women is due in part to his own social anxieties, but also the belief that he must be something else, someone else who can "win over" a woman, not a loser. He believes the playboy fantasies of thawing a frigid woman (as exemplified by the imagined sequence with the imagined Sharon (Mari Fletcher) in which he "cures her"), and assumes reality corresponds to the fantasies. Of course, it cannot be overstated that Allen exaggerates Allan's problems for comedic effect. Allan's problem we might say is hermeneutic: he misreads the situations and the codes. When Sharon (Jennifer Salt), the star of Gang Bang is appalled by Allan's attempts at posing as a sort of well-traveled Renaissance man with his cultural references and demonstration of rice eating, he understands her as "playing it cool" and is convinced "she likes me. I can read women." In part, the solution to Allan's illiteracy is through an experience coaxed out of him by Bogart and coached by Casablanca. Allan's growing relationship with Linda, a woman he cares for, attempts to support, and respects, has an important effect on him.

Bogart is not Allan's only confidant. Allan tells his woes to Linda. Linda is a fellow neurotic who shares Allan's efforts in deciphering anxiety from homosexual panic, and recipes for tranquilizer cocktails. Upon recognizing Linda and Allan's affinity, Dick jokingly suggests that they get married and move into a hospital. Allan and Linda's mutual struggles enable them to recognize each other's vulnerabilities. 
Linda is often left behind by Dick whose seems to always be on business. As a gag that runs through the film, Dick calls his phone service every time he moves locations so he never misses a beat. The beat Dick does seem to miss, however, is Linda. Lonely Linda spends her time with Allan, trying to cheer him up. Linda even heartens Allan's attempts at chatting with women. Walking through San Francisco's parks and art galleries, they chat openly with each other. Their intimate chats continue over the phone, even when Linda is in bed with Dick, and even if Dick is sleeping and Linda must whisper over his sleeping body due to a short telephone cord.

Allan's life takes a turn for the better when it takes on a cinematic quality as he begins to fall for Linda, and learns that love need not be the story he assumed it to be.

\section{Alvy: You're a very good tennis player}

Like Allan, Annie Hall's Alvy Singer is coping with the break down of a relationship and is struggling to make sense of things. Annie Hall can be likened to an analysand in an extended therapy session in which the protagonist tries to recount where the screw up came. Alvy seems to assume that the screw up isn't in his relationship with Annie, but something that occurred to him along the way. The film can be read as Alvy's search for answering the question "what is wrong with me?"

The film begins with Alvy directly addressing the camera, telling jokes on a bare set. $\mathrm{He}$ borrows a joke from Groucho Marx which, he claims, comes from Freud's Wit and Its Relation to the Unconscious (although, it does not): "I would never want to belong to any club that would have someone like me as a member." This joke, he claims, is key to understanding all of his adult relationships with women: Alvy keeps himself out of clubs and out of relationships when a party is willing and wanting to keep company with him. As Richard Raskin (2007) writes, "This 'key joke' functions here as a self-diagnostic tool enabling our hero--as well as the viewer--to conceptualize a particular neurotic pattern in the life of a person who allows his feelings of unworthiness to prevent 
him from wanting any woman who would want him." What may resemble a stand up routine is a setup. Alvy is offering two keys with which to understand him: not only is he uncertain where he fits in, but also his humor has roots in Jewish humor.

There is a second joke that Alvy tells, which often gets overlooked. Alvy describes two older women having dinner at a resort in the Catskills. One kvetches: "Boy, the food at this place is really terrible" to which the other replies, "Yeah, and such small portions." Immediately, Alvy states that this is how he feels about life. The joke may be understood as Alvy admitting his pessimism: life is crummy, and there is not enough of it. However, to simply read Alvy as pessimistic ignores the content and the context of the joke. The setting of the joke is New York's Borscht Belt, a region once known for its Jewish resorts with dinner theatres. Further, the joke taps into Jewish humor in which women, particularly mothers and wives, are presumed to find fault in all situations (Epstein, 2001; Rosten, 1970; Antler, 2007). What is funny is that the women are unsurprisingly unhappy with the food at the resort, which is presumed not only to be kosher and decent, but plentiful. Alvy is not simply admitting to pessimism, but offering a prompt that his sensibility and outlook on life are highly influenced by his ethnicity and religious upbringing. Curiously, the Jewish mother joke had already fallen out of fashion by the seventies, and the inclusion of this joke is seemingly anachronistic. Yet, the joke's anachronism underscores Alvy's preoccupation with coming to terms with his past. Understanding this sensibility will offer alternate ways of reading how Alvy understands his past, and his relationship with Annie.

Alvy retells his memories of the relationship, memories that he jokes about. Again, mimicking a stand-up routine is a set-up, a kind of courtship by our jokester to feel comfortable entering into his story. The silence foregrounds the observational experience as Alvy enters into his own (psycho)analysis. But instead of laying on his back on the couch, as in later scenes, he is sitting up and staring straight ahead making light of the murky matters that preoccupy him. 
The opening reveals the conceits of the film: 1. Annie Hall is not a film about its namesake, but about her former lover who would not want to star in a film that would want him to be its star, 2. jokes, aside, this routine can be likened to an analysis session for Alvy who is trying to figure out where the screw up occurred, 3. Alvy is a cinephile, who uses his love of films, particularly, for cinematic storytelling to retell and rethink his lost relationship, and how it exemplifies his larger discomfort with love and carnal pleasures.

Thomas Elsasser (2005) describes cinephilia as a term that "reverberates with nostalgia and dedication, with longings and discrimination, and it evokes, at least to my generation, more than a passion for going to the movies, and only a little less than an entire attitude toward life" (p. 27). Alvy's cinephilia certainly reveals his approach to life, a life in which he separates the horrible from the miserable, and employs strategies of observation and humor to keep a comfortable distance. Alvy employs cinematic thinking to mull over his life story, which is presented as the content of the film. As Ronald S. Librach (1996) notes both Annie Hall and Manhattan "serves as stages for the personal of the individual whose mind concocted it. Without the dramatic presence of his persona, the worlds of these films would be senseless and indecipherable" (p.161).

The cinematic devices appearing in the film include: direct address to the audience, the reordering of chronology, use of animation, and splitscreen. On several occasions Alvy makes direct addresses to the audiences: during the film's opening, after bringing out Marshall McLuhan he gives an aside "boy, if life were only like that," during Easter dinner with Annie's family he offers a commentary on the difference between families, and then at the end of the film he addresses us to explains that "you try to get things to work out perfect in art because it is difficult in real life." Alvy reorders chronology: he begins his story with his childhood, we then encounter Annie close to the end of their relationship, and Alvy's initial 'la de dah" encounter with Annie is placed a third of the way into 
the film. Alvy simultaneously locates himself in the past and future at the same time: he visits his elementary school, his childhood home under the Coney Island rollercoaster, he later visits Annie's past to meet her 'heavy' thinking ex-boyfriend, and finally Rob (Tony Roberts), Alvy, and Annie visit Alvy's family during the 1945 welcome home party for his cousin. Further, Alvy's reflection paints Annie in a particular light, by literally turning her into a wicked queen cartoon. Split screen is used as a mode of comparison. In order to prove that the Halls and the Singers are like "oil and water," Alvy contrasts the Hall's calm Easter dinner to his own family's rowdy Passover meal. Split screen is used again to compare Annie and Alvy's therapy session - though, Alvy reclining on the couch takes up considerably more space than Annie's chatting in a modernist armchair. The contrasting therapy sessions emphasize how differently they interpret their life together.

Not quite a cinematic device, but a moment only realizable in cinema, is the magical appearance of Marshal McLuhan. While in line at the Waverly Theatre, when Alvy is annoyed by the commentary on Fellini and McLuhan by the academic in line behind him, he brings out McLuhan to correct the academic: "you mean my whole fallacy is wrong." The joke being that McLuhan's theories do not include a fallacy, but his presence in the film recalls his platitude 'the medium is the message'. McLuhan serves to illustrate Alvy's cinematic thinking which removes the limitation imposed on the reality of the 'real world'. Calling upon McLuhan's help to put the professor in his place, Alvy establishes that he is in control of the narrative.

The entry point to Annie and Alvy's relationship is through Alvy's jokey retelling. In order to come to know Annie and the love between them, we must appreciate who Alvy is and his understanding of Annie. In the midst of learning about Alvy in the opening scene, we find out that he just turned forty, and that he and Annie have broken up. "I'm examining my life and trying to figure out where the screw up came from. A year ago we were in love... " he then trails off to share parts of his 
childhood. Alvy was a depressive youngster, paralyzed with worry about the universe expanding, slouching on a couch as a cigarette smoking Dr. Flicker (uncredited actor) with his husky voice and sinister laugh encourages to enjoy life while he can. Alvy's childhood home is under a rollercoaster at the Coney Island theme park, a shaky start for a myopic tyke trying to slurp tomato soup and read comic books. Meeting his classmates he sets the stage for his later quip that he is a "relatively normal guy for someone who grew up in Brooklyn." Annie is introduced six scenes into the film, when she arrives via taxi, late, in a bad mood while Alvy has been fending off "two guys named Cheech" in front of the Beekman theatre.

Annie Hall, as this drifting story enacts, is a film about Alvy Singer recollecting his life through the break down of a significant relationship. As he recollects, he begins to put together his own queries of the meaning of life and the possibility of love. Annie is not Alvy's first love. She is his third, or maybe more. Before her there are Alison (Carol Kane), and Robin (Janet Margolin), women who are caricatured by Alvy and are what Annie calls "those smart, New York types." We meet Alison Portchnick a graduate student writing her thesis on political commitment in Modern Literature, whom Alvy quickly sums up as a cultural stereotype. He used to be "so hot" on Alison, then something changed, and he fretted over the JFK assassination as an excuse not to make love to her. Robin, who is having her book published, is eager to please a room of intellectuals and show her allegiance in the 70's scene. Clad in a paisley caftan and oversized aviator glasses, she waves at the big names, including Paul Goodman, in the room, and refuses to 'quietly hump' Alvy while everyone else is ' discussing modes of alienation'. In a later bedroom scene, Robin has her orgasm interrupted by ambulance and demands valium; she is too tense to make love to Alvy. In both cases distractions — fake or occurringbecome a scapegoat from intimacy. Alvy's previous relationships not only cooled off, but were characterized by a kind of disembodiment — an inability to be 'in touch' with their bodies. 
Annie is unlike these two. Alvy meets Annie during a game of doubles tennis. After the game, she comes off the tennis court in a nervous state. Speaking to Alvy alone induces a series of stammers on her behalf, "o pff" "yeah, well.. oh well... well." Annie is unlike this in later scenes, with her peachy keen, neat, sweet way of talking. Alvy, albeit slightly farshvitst, is cool and calmly puts away his tennis racket while complementing her tennis skills. Annie offers Alvy a lift. As Annie speeds and darts around what appears to be the meat packing district, Alvy finds an old sandwich in her car, and tells her she "keeps it nice." Annie never asks Alvy where it is that he wants to go, and so she brings him home. In her apartment, we learn about her fondness for Sylvia Plath, her feel for photography, her family (Sadie; Grammy Hall; the shell shocked, narcoleptic cousin who died while getting a turkey; her brother, Dwayne), her open schedule and reluctance to date. These details are important, not simply because they give us a sense of what Annie is like, but they reveal to us how Alvy has remembered her.

Annie is clumsy; bumping around her apartment, waving her arms frantically explaining the shell shocked relative; her face grows red, her hair becomes stringy, and "O, no, no" her manner of speaking suddenly becomes a cross between a child in the Norman Rockwell painting that Alvy teases her about growing up in and a frenetic, high, teenager, who is eager to amuse the new boy she had just met. Annie begins as a caricature, but becomes something more gentle and nuanced through the duration of the film. As Alvy's affection for Annie grows so too does our impression of her.

On a summer afternoon, Annie and Alvy enjoy the sun in Central Park. They observe a kooky cast of New Yorkers while Alvy offers mini narratives of them: Mr. Miami Beach, back from the gin rummy finals; the winner of the Truman Capote lookalike contest; the man in the "linen supply or construction", etc. Alvy is showing off his cultural prowess, wise cracking at the expense of others. While Annie can take pleasure in his teases, later she is uncertain if his jokes are serious jokes or jokey 
jokes. Alvy's indirect communication confounds Annie, but reveals how baffled Alvy is as a result of his belief that he does not fit in, and his desire to be with Annie, which implicitly is a kind of fitting in.

\section{Cecilia: You'll Like This One, It's Romantic}

The Purple Rose of Cairo takes place in the late 1930's, in the middle of the American Depression. Cecilia is a classic movie-struck gal, a cinephile, who loves the adventure and splendor of the stories on the silver screen. Like Allan, Cecilia's story begins at the movies, and to the movies she returns again and again.

Cecilia stands outside of the Jewel, admiring a movie poster with an illustrated rendering of the great pyramids and the sphinx, two tuxedo-clad men raising glasses of champagne as if to toast, a sultry black-bobbed, smoky-eyed woman, and tall simple purple lettering reading: The Purple Rose of Cairo. Her gloved hand rests over her mouth as her eyes stare straight at the poster, Cecilia is already enchanted. A crash rouses her, and the man changing the lettering on the marquee of the Jewel calls down: "You'll like this one it's more romantic than the one last week." Unbeknownst to Cecilia, her romantic life is about to be more exciting than last week as well.

As Cecilia walks home, toting the laundry she washes to make extra money, she passes a group of unemployed men, who gather on a dusty street corner to shoot crap and pitch pennies. Monk (Danny Aiello), Cecilia's husband, is their bullying ringleader. Cecilia encourages him to forget his troubles and join her at the movies—after all, she says "you're never home anymore." Defensively and aggressively, he shouts: "listen Cecilia, you like sitting through that junk, okay? I'll shoot crap, okay?"

That night, with a ticket for one, Cecilia returns to the Jewel to visit the pyramid, the sphinx, and discover The Purple Rose of Cairo, meanwhile Munk is at home showing the buxom Olga (Camille Saviola) some cards tricks.

The next morning, Cecilia struggles at her waitressing job while trying to serve breakfast. 
Overlapping voices of customers call out to her as she drops dishes, confuses orders and forgets cheques. Cecilia blunders in her job as a waitress because her mind is out to lunch, at the movies. Her dreamy antics have her fired. Down on her luck, and with no place to go — no place to go but home to her gambling, philandering husband, Munk —Cecilia retreats to the Jewel Theatre for another screening of The Purple Rose of Cairo. Sitting in the dark of the matinee, she relaxes.

Jackie Stacey (1994) notes that there are few reliable sources on female cinema attendance from this time, but her interviewees reported similar habits to Cecilia's repeated attendance. The camera closes in on Cecilia's enamored face. The focused patrons and rows of wooden theatre seats retreat into an indistinguishable blur: it is just Cecilia and the screen. Cecilia sits in the comforts of the cinema for five sequential screenings.

Where cinematic thinking for Allan and Alvy is illustrated through cinematic devices, Cecilia's cinephilia takes on a direct phenomenological encounter with the cinema. Tom Baxter, of the New York Baxters, is an explorer, as evidenced by his pith helmet and safari suit. Tom proclaims his joy as he and his socialite friends are "on the verge of a madcap Manhattan weekend." Unlike the previous five screening, suddenly Tom glances at something in the distance. His eyes soften as they steady on a far off point. "You've been here all day," he exhales. A confused Cecelia looks around. He literally calls out to her. He zeroes in on the unsuspecting patron: "hey you, no, no you...you've been to see this picture 5 times." Gasps echo through the theatre. Cecilia raises her gloved hands to her face. Tom Baxter, a black-and-white moving image, steps forward off the screen and transforms into a colourful moving human. For Sam Girgus (1993), "The utterly impossible act of a character leaving the screen to talk to an infatuated fan already has psychological validity and artistic coherence" (p. 78) since the fantasy has already been thought through by Cecilia. Cecilia's brings this fantasy to life, and Tom to 
life. $^{23}$

As the Countess (Zoe Caldwell), Henry (Edward Herrmann), Rita (Deborah Rush) and Jason (John Wood) press against and bounce off the fourth wall, Tom grabs Cecilia's hand and makes a run for it. Henry calls out: "Listen old sport, you're on the wrong side." Outside of the screen, outside of the cinema, in the sun and with Cecilia's hand in his, Tom looks Cecilia straight in the eyes and says: "I'm free." Indeed, Tom is free to create his own story: to fumble, to foible, and to fall in love. As Tom explains himself: "How many times is a man so taken with a woman, he walks off the screen to be with her?" With Tom off the screen, Cecilia transforms into her own leading lady.

\section{Mickey: I Had a Great Time. It Was Like the Nuremberg Trials.}

Hannah and Her Sisters does not focus on the story of one character, but follows an ensemble cast through personal details, each somehow related to Hannah. Mickey is Hannah's ex-husband. Where the scenarios of Allan, Alvy, and Cecilia center on romantic and intimate relations with the other, for Mickey love and life are inextricably bound up. Mickey's woes deal less with his love life, and more with his lack of love for life, with his intense job working in television, his hypochondria, and, most importantly, his search for meaning in life. Life, for Mickey, is meaningless, and he despairs to find meaning. Mickey begins the film as a solipsist who clamors for a higher purpose, and eventually finds salvation not in a savior, but in the mundane pleasure of just being part of life.

Mickey works in a television station, where people constantly clamor for his attention: actors require encouragement, fact checkers demand answers, and the standards person refuses to approve

${ }^{23}$ Tom Baxter walking off the screen is a moment where Allen's interest in film history, specifically early comedies shines through. Allen offers a homage to Buster Keaton's Sherlock Jr. in which an affable, romantically-preoccupied projector operator falls asleep while on duty. As he sleeps, he imagines himself entering into the film that he's projected and watched numerous times; while on the screen the projectionist solves the case of the missing necklace and wins over his sweetheart. Unlike the projectionist whose fantasy puts him onto the screen, the fantasy of The Purple Rose of Cairo takes Tom Baxter from the screen. 
jokes. Mickey laments his decision to remain with the hub-bub of the industry in New York. As he daydreams, a voice over narration and cut reveal his ex-partner Norman, played-of course- by the Allenesque character's favorite sidekick, Tony Roberts, now successful, smiling and bopping to music as he drives his shiny convertible to work in California. Mickey, on the other hand, seems to be always distracted and preoccupied. Mickey's tweed blazers and trench coats are rarely removed as if to ensure a speedy getaway. Even on the birthday of his twin sons (Allan and Artie DeCheser), he only visits briefly. Hannah, cleverly using television lingo, says she is glad he could at least make an appearance.

Concerned over some potential hearing loss, Mickey visits the doctor and attempts to convince him of his ailments, "this time I really think I have something." Like Allan and Alvy, Mickey looks to his past to confirm how things will work out. All three convince themselves of living through a streak a bad luck. During Mickey's previous experience receiving medical testing, the doctor pronounced him unable to have children (Norman, Mickey's former partner, is the boys' biological father). Despondent, Mickey decides he needs answers.

Like Allan and Alvy, psychoanalysis has not offered Mickey resolution: "I was in analysis for years and nothing happened. Poor guy finally put in a salad bar."24 His search takes him to the library to read the great philosophers, to a Roman Catholic priest, and even to the park to speak with a group of Hari Krishnas. Mickey attempts Catholicism most heartedly, and even offers to dye Easter eggs-"if it helps." Mickey may confuse Orthodoxy with Catholicism, but his intention is set. He attends sung masses and purchases the appropriate paraphernalia. From a brown paper bag, he pulls key artifacts that reveal his 'conversion': a crucifix, an icon, mayonnaise (but, not miracle whip), and wonder bread.

\footnotetext{
${ }^{24}$ Despite the common assumption that Woody Allen's films endorse, Mickey is not the only character who experiences resolve outside of the analyst's office. Indeed, as Deleyto (2006) points out "Isaac undergoes the classic moment of crisis out which recovery (and discovery) will emerge" (Deleyto, 2006, p.30), but Isaac's transition happens on the couch in his living room, rather than the analyst's couch.
} 
While the crucifix and icon can be considered Catholic essentials, the mayonnaise and white bread signal that Mickey has given up his Jewish preferences. Again, like Alvy's reaction when Annie orders the pastrami, condiments are cultural signifiers. Although neither character outright cites the old Milton Berle joke, "anytime somebody orders a corned beef sandwich on white bread with mayonnaise, somewhere in the world, a Jew dies," there is a continuity of the cultural assumption that Jews dislike mayonnaise and white bread, and are in favor of ordering pastrami with mustard on rye. By purchasing mayonnaise and white bread, Mickey has symbolically 'killed' his Jewish identity.

When religion falls short of offering Mickey answers, he wonders if "maybe the poets are right? Maybe love is the only answer." Looking through his past, he reminds himself that things did not work out with Hannah, and then she set him up with her sister, Holly. Holly's off-beat style, interest in underground music clubs, and cocaine habit are the opposite of Mickey's conservative khaki, jazz club, and tea-totaling ways. Mickey is uncomfortable with Holly, and is quick to judge her. Holly rightly describes Mickey as stuck-up, and sums up his problems: "You don't believe in ESP. You don't dig rock music. You won't get high.” Mickey declares her polymorphously insensitive, and outright tells her, "You don't deserve Cole Porter." Too, he gripes, "I had a great time. It was like the Nuremberg trials." After the two part ways, he sighs, noting that he "always had a little crush on her." While their first encounter did not develop into a romance, Mickey's intuition leads him not only to love, but to the answer he seeks.

The cinematic analysis introduced the cold feet of Allan, Alvy and Mickey, and the sweet Cecilia to explicate the obstacles they face and their preconceptions of love. While their current experiences of their embodiment include nervousness, anxiety, apprehension, and antagonism that manifest as sweating, shaking, jitters, quivers and stuttering, they each have an acute awareness of their bodies. Their awareness of sensations will help them to transform their experience of love. While they 
struggle with people and love, the cold feet of Allan, Alvy and Mickey, and the sweet Cecilia are open to the experience of the cinema. The cinematic other serves as a kind of practice site for encountering the lover. The following chapters will explore how their experience in the cinema can assist them in being open to the experience of love. 


\title{
Chapter 4: \\ Looking for Love in the Cinema with Woody Allen
}

\author{
"The atmosphere is heavy with love. \\ I am looking." \\ Jean Epstein, [1921], p. 241 \\ "I want what happened in the movie last week to happen this week; \\ otherwise, what's life all about anyway?" \\ Moviegoer, Purple Rose of Cairo
}

The previous chapter explicated a phenomenological method of film experience that approached the relationship between cinephile and screen as a relationship between two. The previous chapter also introduced the predicaments of the nervous romantics, and described their outlook on relationships with people and the cinema. It is the intention of this chapter to explore the bodily experience of the cinema and the bodily experience implied in cinematic thinking in order to theorize the transformation of nervousness in the cinema.

\section{Radiant Nervousness}

The writings of Jean Epstein are steeped with commentary on the relationship between the cinematic image and the bodily experience of the cinephile. Most expressive is Epstein's account of the close-up. In his essay Magnification, Epstein (1988 [1921]) makes clear that it is not simply camera technique that intensifies or directs the relationship between screen and spectator, but cinema generally: "If cinema magnifies feelings, it magnifies it in everyway. Its pleasure is more pleasurable, but its defects are more glaring" (p. 240). Prior to Merleau-Ponty's phenomenology of intersubjectivity, Epstein already recognized the interplay between the cinema and the spectator, emphasizing the embodiment and exchange that occurs while present at the cinema: "The film is nothing but a relay between the source of nervous energy and the auditorium which breathes its radiance" (1988 [1921], p. 238). The cinema as a space of embodiment and exchange is central to the transformation of the nervousness of the nervous romantic. 
Further, Epstein (1988 [1921]) emphasized nervousness, claiming "the gestures which work best on screen are nervous gestures" (p. 238). "It is paradoxical, or rather extraordinary, that the nervousness which are often exaggerated reactions should be photogenic when the screen deals mercilessly with the least forced gestures" (Epstein, 1988 [1921], p. 238). The paradox that Epstein raises is between the intensity of expression and its naturalness. Play it Again, Sam's Allan's awkward movements - a slippery dance of flailing limbs that inevitably knock over objects and risk endangering by-standers - appear to exceed a 'normal' level of nervousness. However, these gesticulations are sincere. At the heart of the experience of the nervous romantic is their nervousness, and the humor they utilize to negotiate their way in the world.

Nervousness may be at the center of the experience of the nervous romantic, but this nervousness does not occur at the emotional core of the film. At the emotional core of these films is love: struggling with wanting love, fear of love, and playing games that distance the self from love.

The nervous romantic is a misfit who has not quite found a way to fit in. Socially awkward, Allan uses his perceptive abilities to review films for Film Weekly. A comedian, Alvy uses his sense of humor to negotiate social situations and offer cultural commentary. Like Alvy, Mickey's humorous coping strategies allow him to participate in New York's culture and entertainment industry, while maintaining his distance. Day-dreamy, frightened, and jittery Cecilia is fired from a waitressing job, is mistreated by Munk, and is later sweet-talked by Gil Shepard (Jeff Daniels). Their nervousness could be a response to being rejected, not only in romantic situations, but socially and within the familyespecially the early rejection by their mothers who criticize them for trying to be themselves. As John Russon (2003) explains our sense of self develops in cooperation with our social relationships, especially the family in early life. The family puts demands on the individual to "give over the rights claimed by [their] singularity for defining [their] identity in favor of the right of the particular group to 
give it an identity (Russon, 2003, p. 68). Perhaps, Alvy's palatable misanthropy could be a response to continually not fitting in: his family rejects his worries of the universe expanding, he is convinced his Jewishness results in judgment from others, and membership in any club seems an impossibility. Regardless of the origin of the nervous romantic's nervousness, the present condition of nervousness frames their experience of the world and their experience of love. As a result, their nervousness determines the conditions for their transformation.

The analysis in this chapter first takes up nervousness as a trope in Allen's films, and then proceeds to understand the affective experience, the nervousness, of the Allenesque character. The transformation of the experience of nervousness in the Allenesque character is the focus of this chapter. The Allenesque character is both nervous, and a cinephile. Both of these qualities suggest their extraordinary sensitivity. It is precisely this sensitivity that enables them to experience the world differently, and it is this sensitivity with which they encounter the cinema. The embodied insight of the Allenesque character's encounter at the cinema offers the key to their transformation.

Woody Allen is perhaps best known, and most lauded, for his nervous romances: Annie Hall and Manhattan. The nervousness and the preoccupation with romance is not limited to these films, but extends throughout Allen's oeuvre. ${ }^{25}$ The cold feet of Allan, Alvy, Cecilia and Mickey are the nervous romantics who have formed the basis of the analysis of love here. However, provided the analytical attention bestowed upon Annie Hall and Manhattan by scholars of the romantic comedy, this chapter will make additional reference to the transformation of Isaac. Further, the academic analyses of Annie

${ }^{25}$ Written as a play and then later made into a film, Play It Again, Sam is often over looked as a nervous romance. Play it Again, Sam is written by and stars Woody Allen, and is directed by Herbert Ross. As Peter Cowie points out "so faithful was Ross to the spirit and letter of the play, and so forceful was Allen's performance as the would-be Bogart, that for most audiences it was a film by Woody Allen" (p.12-13). With its discussion of psycho-analysis and anti-anxiety cocktails, use of stuttering awkward banter that delays intimacy, the support of Humphrey Bogart (Jerry Lacy) as an imaginary friend and romantic coach, and an ambivalent ending that finds our (anti) hero at a loss for love and single, Play it Again, Sam presents the symptoms of a classic Woody Allen romance. 
Hall and Manhattan not only approach them as nervous romances, but as romantic comedies that provide particular insight into the transformations of the protagonists.

Romantic comedy genre theorists (Krutnik, 1990, 2002, 2009; Mortimer, 2010; Deleyto, 1998, 2006, 2009; Jeffers McDonald, 2007) acknowledge Allen's contribution to the genre in the seventies, but then Allen's "name disappeared from the conversation" (Deleyto, 2009, p. 51). Allen's work may not qualify for all the formal criteria of the genre of the romantic comedy, but his work obsessively returns to inquire into what Deleyto (2009) deems to be the "main discursive space" of the romantic comedy: "the exploration of love and human sexuality and its complex and fluid relationships with the social context" (p.28-29).

The term romantic comedy results from the intersection of laughter and interpersonal narratives, and can "designate a bewildering array of possible combinations of sex and comedy" (Krutnik, 2002, p. 133). Typically, romantic comedies are understood to be light and amusing tales dealing with everyday life (Neale and Krutnik, 1990). For Claire Mortimer (2010), the elements that compose a narrative typical of the genre include: boy meets girl; obstacles prevent them from being together; they endure coincidences and complications; they realize they were meant to be together; and finally, the narrative concludes with the union of the couple, the happy ending. The key feature of a romantic comedy is the "central quest — the pursuit of love [which] almost always leads to a successful resolution" (Mortimer, 2010, p.4). The happy ending is the most oft-cited feature of the romantic comedy. Predicated on the fantasy maintained by the happy ending, Rowe (1995) has argued that the romantic comedy genre has persisted because "it speaks to powerful needs to believe in the utopian possibilities condensed on the image of the couple" (p. 212). The romantic comedy, as Abbot and Jermyn (2009) stress, is a living genre that "continues to negotiate and respond dynamically to the issues and preoccupations of its time" (p. 3). Allen's main contribution to the genre is not only the injection of nervousness, but the 
exploration of sex and the ambivalence of 'happy ever after.' The image of the couple and the path to coupledom has undergone changes from the screwball comedies of the thirties and forties to the sex comedies of the sixties to the nervous romances of the seventies and early eighties, evolving again with the new romance in the eighties. There is little in the world of Woody Allen that is light; however, the gravity of relationships and self-inquiry is a recurrent topic for Allen, and one that captures the zeitgeist of the seventies.

Brian Henderson (1978) observed that the beginning of the sixties initiated an interest in selfdiscovery and a deepening of the relationship with the self. Sex had become a path for self-discovery and self-liberation. Henderson (1978) predicted that this new interest in the self would bring about the death of the romantic comedy. What Henderson (1978) could not predict was the emergence of Allen's nervous romances that treated the discovery of the self and the endless inquest into the meaning of life as part and parcel of the journey to finding romance. Indeed, as Celestino Deleyto (1998) wryly jokes, these films are "romances or self-analysis" (p. 164). Annie Hall in particular takes the form of an analytic session as Alvy sits on a stool, stares straight into the camera and asks: "where did the screw up come?" The screw up he is looking for is not only in his relationship with Annie, but in his life generally. The narrative conceit of Manhattan is that in Isaacs attempt to write a novel by narrating it to his tape recorder, he simultaneously shares concise summaries of the film. His book is about people who "take the easy way out", and who "create unnecessary neurotic problems for themselves because it keeps them from dealing with more unsolvable terrifying problems about the universe.. uh okay, why is life worth living?" In this way "the romantic comedy is recast as an existential mystery" (Grindon, 2011, p.152) which brings together the themes of love and the meaning of life.

While the general nervousness expressed by the Allenesque character was not a new trait among characters of the romantic comedy genre, the particular nervousness inflected in Allen's films 
were "less superficial character traits and more thematic tropes" (Stillwell, 2009, p. 29). Nervousnessparticularly nervousness about love and romantic relationships, and their relation to the meaning of life - is the theme in Allen's films that take the emotional balance of the narrative. Annie Hall and Manhattan are typically singled out as films that signaled a shift in the romantic comedy, and inaugurated a sub-genre of the nervous romance which include: Starting Over (1979) and An Unmarried Woman (1978) (Krutnik, 1990; Mortimer, 2010; Deleyto, 2009).

The nervous romance cycle of films takes their name from the tagline of Annie Hall: a nervous romance. At its heart the nervous romance is characterized by "a nostalgic yearning for the lost possibility of romance and a more cynical awareness of the difficulty of maintaining an overriding faith in The Couple in the face of the divisions which beset modern life" (Krutnik, 1990, p. 62). Geoff King (2002) goes so far as to suggest that the nervous romance signals the impossibility of romance (p. 57). The films of the nervous romance represent uncertainty about relationships, and emphasize the attempts of the individual to make sense and find meaning in romance and existence--a boiled down summary of most Woody Allen films, if there ever was one. Claire Mortimer (2002) describes the attitudes expressed by the nervous romance as "in favor of greater realism" by rejecting the happy ending, even if Allen's films "films do not offer easy pleasure for a mass audience, with their references to other art works, criticism and psychoanalysis" (p. 17). Neither Alvy or Isaac find love, nor do Allan or Cecilia, but they do arrive at a key insight bridging love and the meaning of life leaving them ever more sweetly attuned to the possibility of love.

Allan examines sex in more "frank detail than is typical of the genre" (Mortimer, 2002, p . 91). The nervous romance casts the bedroom as a locus of panic and anxiety. Drugs, medical and otherwise, help to seal the deal in Annie Hall: when Alvy Singer's second wife, Robin (Janet Margolin), is distracted by the siren of an ambulance and unable to reach climax, she demands a valium; and, Annie 
needs to make love high, lest she feel disembodied. ${ }^{26}$ Unlike the sex comedies of the 1950 's and the 1960 's in which men attempted to win over women who may or may not be willing to go to bed with them, conversation becomes a way to delay intimacy; "verbal conflict is no longer primarily foreplay, but an articulation of real anxiety" (Stillwell, 2009, p. 29). Alvy obsessively discusses the JFK assassination to avoid sex with Alison (Carol Kane). And, while seeking shelter from the rain, Mary lists Saturn's moons to delay Isaac's advances to commit interstellar perversions. In order to appease the butterflies in his stomach, Alvy asks Annie if they can kiss before dinner so they can "digest better." Anxiety arousal, not sexual arousal, is a symptom of romantic and sexual interest.

Through the nervous romance, Allen was understood as "reinventing a tired and predictable genre" (Abbott \& Jermyn, 2009, p. 2), specifically by questioning the most assumed criteria of the romantic comedy: the happy ending. The happy ending is a metonymy of the unification of a couple, whose happiness is assumed to be guaranteed by their union or better through marriage, and presumed to last ever after. ${ }^{27}$ As will be discussed in the next chapter, the unity of the couple or the unification of the final couple - to borrow a term from MacDowell (2013) — is less important than the self discovery of the protagonist.

Still in Allen's nervous romances, following the structure of the romantic comedy narrative, the protagonist undergoes a last minute resolution. The ultimate scene of the nervous romance rewrites the happy ending as the result of a personal journey through anxiety and fear into the clearing of hope

\footnotetext{
${ }^{26}$ This disembodiment is in contrast to Alvy's bodily sensitivity that must be cooled off "with another in a series of cold showers." Alvy does not struggle with erotic embodiment, but instead delays or refuses intimacy by babbling.

${ }^{27}$ MacDowell (2013) argues that 'the happy ending' is a Platonic type or prototype that does not actually exist in Hollywood films, and the belief in the happy ending assumes the entire romantic comedy to be conservative, a hangover of Althusserian ideological critique that Deleyto also acknowledges. The happy ending remains as a discursive short-hand for an up-beat, optimistic narrative closure.
} 
through finding meaning in romantic relationships. The narratives end, leaving the nervous romantics single, but hopeful (with the exception of Mickey who is both partnered and hopeful). Isaac's eyes are widened by the mature knowledge of Tracy who encourages him to find faith in people. Alvy realizes that relationships are a messy, but a necessary part of life and is happy to just have spent time with Annie. Allan finds the courage to articulate his feelings, and is prepared to look for love. Cecilia gains the courage to leave Munk, is able to enjoy the swelling romance of Fred and Ginger, and looks ahead to a happily ever after on her own terms. For Mickey, the resolution comes earlier, opening him to give love and Holly, a second chance. The development of the nervous romantic is made possible through the space of the romantic comedy, which is re-located to the urban for the nervous romantic.

\section{The Space of the Nervous Romance/Romantic Comedy}

Central to the romantic comedy is the creation of the space of romantic comedy. "Through its comic perspective on cultural discourses on love and desire, romantic comedy proposes an artistic transformation of the everyday reality of human relationships by constructing a special space outside of history (but very close to it)" (Deleyto, 2009, p. 30). Space in this context both is and is not a metaphor. In its classical usage, the space of the romantic comedy assumes the green, pastoral space of the country side. Celestino Deleyto (2009) scaffolds on the genre theorizations of Northrop Frye, Leo Salingar, and Barbara Thomas that follow a protagonist as they leave their society to discover themselves, and then integrate back into their society with their new found self-knowledge. The nervous romantic likewise endures transformation, however, their journey does not take the form of travel. Instead, they experience an inner journey through which they stand on the brink of isolation, only to traverse their romantic anxiety to locate new potential in love.

The comedy of the space of the romantic comedy is essential to the transformation of the protagonist, as it is through the comedic that the transformation happens. Where the comic describes 
something that provokes laughter, the comedic is quality of space (Deleyto, 2009, p. 33). This quality of humor permits the transformation in ways different from that of the romance and melodrama genres. Again, the space is both a physical location, a place, but also a bracketing or an aperture. Deleyto (2009) emphasizes that this space is humorous and benevolent (p. 34), permitting the character to momentarily envision "a 'better world', a world which is not governed by inhibitions and repressions but is instead characterized by a freer, more optimistic expression of love and desire" (Deleyto, 2009, p. 36). Where the space of the romantic comedy momentarily brackets cultural discourses on love and sex in order to question taken for granted assumptions and beliefs, to quell the quivers of the nervous romantic the space must quiet and soothe hesitation and anxiety in order to access a different set of affects allowing a change of attitude on love and sex.

As in the comedies of Shakespeare, the pastoral space or the countryside is a typical site of transformation. The countryside, with the moths in the windows and the Manson family living next door, as Alvy describes it, is not the preferred site of the cold feet, or any of the Woody Allen romantic types. The cold feet do venture beyond the urban jungle: Allan goes away with Linda and Dick for a working weekend at a resort; Alvy and Annie rent a cottage in the Hamptons, twice; and, Isaac and Mary make love — successfully—in a cabin. However, the rural is a site of threat and discomfort: Love and Death's Boris describes nature as an enormous restaurant with "spiders and bugs and big fish, eating little fish and plants"; Interior's Renata cannot even bare to look at trees without noting that in nature "everything seems.. sort of awful...and predatory"; out in the sun, Allan does not tan, he strokes and, not even A Midsummer Night's Sex Comedy's Andrew Hobbes, who lives in the country, is at home in nature.

Thus, Allen undoes the typical association of the green comedies as a literal and discursive space that promotes character transformation. Allen, particularly, in A Midsummer Night's Sex Comedy, 
is "destroying a Shakespearean pattern" (Morris, 2006, p.53). For Morris (2006), Allen "raises these classical expectations ironically, only to undermine them with nihilistic conclusions that challenge the possibility of romantic or social harmony" (p. 53). Such a totalizing reading of Allen is all too harsh, but Morris gives way by arguing that for Allen "love is consigned to the realm of art, not life" (2006, p. 55). Yet, Morris makes an oversight. As Maurice Yacowar (2006) points out, there is one person who does become transformed in the 'green world':

The conversion of the arrogantly materialist philosopher, Leopold (Jose Ferrer) into a romantic spiritualist; the man of culture rediscovers his savage impulses. Leopold is suitably liberated from the limits of the flesh and narrow intellect by the candid and open Dulcy Ford who despite her inferior education can both beat him in chess and literally fuck him to death, which frees him into a greater life. (p.81)

Nature transforms the lone philosopher, Leopold, but not the pseudo-philosopher, the Allenesque character.

It is not only that the space must be different, but there is another strategy at work. The pastoral space takes the characters out of their usual surroundings and out of their taken-for-granted assumptions; to be in the green space is to be out of the typical discursive environment. However, it is not enough to be simply transplanted, to be moved. In the case of Vicky Cristina Barcelona's Cristina and Vicky, "being taken out of their situation" and spending a summer in Barcelona opens them to new scenarios under the auspices of a romantic Spanish summer. They traverse the city through artifacts and galleries, and Juan Antonio notes how deeply moved Vicky is by the music of a classical guitarist in Oviedo. It is not simply that they have moved physically, but are emotionally moved. In Woody Allen's films, the transformation occurs not by taking the character out of their discursive space as a literal space, but by enabling them to access their feelings. Indeed, the nervous romantics prefer to pound the pavement seeking cultural sites of creativity wherein they can relax, and momentarily let go. What moves is not the sublimity of nature, but the mundane, yet magical feats of culture. 


\section{Cultural Space of Transformation}

Woody Allen does not distinguish between high and low cultural forms. Indeed, Alvy would rather watch the Knicks game than chat with the chairs of various philosophy departments, who are missing a table to complete their dining set and Manhattan Murder Mystery's Larry demands to go home early from the symphony to catch the Islanders game. Magicians and magic shows are featured in Stardust Memories, Oedipus Wrecks, Shadows and Fog, The Curse of the Jade Scorpion, Scoop, and Magic in the Moonlight. ${ }^{28}$ The symphony, music halls, and nightclubs are featured in Manhattan Murder Mystery, Take the Money and Run, and Annie Hall. Art galleries and museums are featured in Play it Again, Sam, Manhattan, Mighty Aphrodite, Matchpoint, and You Will Meet A Tall Dark

Stranger. The cinema is the ultimate place of transformation. The cinema holds space for the characters to tune into their embodiment in Play it Again, Sam, Annie Hall, The Purple Rose of Cairo, Manhattan, Hannah and Her Sisters, Crimes and Misdemeanors, and Hollywood Ending. As Manhattan's Yale so succinctly states: "the essence of art is working through a situation to get in touch with feelings you didn't think you had."

\section{Art and Creativity}

In addition to the cinematic devices that were assumed to be a form of fantasy, Allen's positioning of the arts and creativity has been assumed to be another form of flight from harsh reality (Detmer, 2013; Bailey, 2001). For David Detmer (2013), "art represents the abandonment of reality in favor of an unreal and unstable fantasy world" (p. 268). Similarly, for Peter J. Bailey (2001) art simplifies life's complications: "The great boon of art is that it is easier to resolve than life" (p. 34). Certainly, Alvy is momentarily complicit in such an implication when in his play, which is a thinly

${ }^{28}$ When Max Kleinman decides to join the magician rather than building his life with his second finacée, as Lee observes, "[h]is journey is not towards fulfillment through a romantic relationship; it is a more private quest that will require his withdrawal from practical society" (1997, p. 306). 
veiled working through of his relationship with Annie, the couple not only ends up together, but with a head-tilted melancholic look, Alvy then addresses the camera, seeking empathy, saying "What do you want? It was my first play?" It is only Yacowar (2006), in his analysis of A Midsummer Night's Sex Comedy who understands art not as a form of escape, but as offering an alternative way of considering the present. Yacowar (2006) describes the process of creating art as making something out of nothing. This making is precisely what Andrew does in his creation of the spirit box. Andrew's invention "anticipates filmmaking. Since it projects images of romantic potential for its characters to realize" (Yacowar, 2006, p. 81). The moving images serve as inspiration — as art—and for Andrew, the spirit box "change[s] his world by allowing the lovers to increase their understanding" (Yacowar, 2006, p. 81-82). Implicitly, what Yacowar acknowledges is that while in the countryside, experiencing art has impacted Andrew and Adrian, and their guests. Rather than the countryside or the green world, it is the image of a potential love projected by the spirit box that has enabled them not to evade their approach to love, but to access - perhaps another way — an approach to love. In other words, the characters access another approach to love through their relationship to a projected image.

Art and creativity have a privileged relationship to emotion within the films of Woody Allen. Isaac concurs that "nothing worth knowing can be understood through the mind." The space of the nervous romance is a creative space that allows access to bodily experience without an immediate grappling for security or the comfort of a pill. For a transformation to occur, the character must embrace the saturation of experience. ${ }^{29}$ The question is not which medium can initiate a transformation, but if the medium arouses the relation necessary for transformation. For the exemplary nervous

\footnotetext{
${ }^{29}$ As will be discussed in the proceeding chapter, for Jean-Luc Marion, the other is a saturated phenomenon. Saturated implies that they fill up the perceptual field, and as a result their presence is in excess of our understanding.
} 
romantics, the cinematic medium offers a modality in which they are comfortable opening themselves to a saturation of experience that initiates a changing embodied understanding of love.

\section{Allan: Nothing a Little Bourbon and Soda Couldn't Fix}

For Allan, like for the Sontagian cinephile, "Cinema was both the book of art and the book of life" (Sontag, 1996). Allan's life takes on a cinematic quality as he begins to fall for Linda. Not only does Allan suddenly find himself caught in a love triangle mimicking They Drive by Night (1940), but Allan also begins to consider Dick's reactions to finding out about his feelings for Linda, each possibility inflected with a different generic form. The transformative space of the cinema, it cannot be overstated, is both a physical space and a metaphor. It is not necessary that a character be present in the theatre, but that they are able to use the unencumbered embodied experience to enlighten their experience elsewhere. Allan is immersed in the cinematic: he writes articles, reviews, and does interviews for a cinema journal; his apartment is strewn about with artifacts; he thinks in cinematic terms of genre and parody; he has Bogart as an imaginary friend; and, he borrows lines from movies. What Allan has not yet allowed for is the sensorial immersion of the cinema to influence his sensorial experience of love.

As a friend, Linda manages to calm Allan, but once he is aware of his affections for her, his clumsiness returns, though in a less clownish form. Sitting in a San Francisco park on a sunny afternoon, Linda asks Allan if he would like to dine with her. With champagne and steak left over from a failed date, Allan invites Linda to recuperate the ingredients, dine in, and watch The Big Sleep (1946) on television. Excited about their plan, the two get up to prepare, and Allan gently takes Linda's arm in his. Allan's voiceover reveals his self-discovery: "I have a terrific rapport with Linda." Already, Allan begins to imagine the best of all possible scenarios: Dick, dressed in furs, admits to having an affair with an Eskimo woman. While running to catch a plane, Dick asks Allan to take care of Linda and, of 
course, should he be needed they can reach him by phone at frozen tundra 6-9290.

Linda suggests they skip The Big Sleep in favor of an Ida Lupino movie about a woman who is in love with her husband's best friend. When Allan asks how it ends, Linda replies, "well, she kills him herself," and a panicked look spreads across Allan's face. The film that Linda is referring to is They Drive by Night, a film about long-haul truck driving brothers, which stars Bogart. Allan, being a Bogart aficionado, I would assume, would not only know about the film, but understand that the "he" Linda is referring to is not the best friend-cum-lover, but the husband whom Lupino 'accidentally' kills in a car accident. They Drive by Night is a curious omission from Allan's Bogart archive.

The reference to the film gives Linda occasion to ask Allan if it is possible to love two people at once. While he mumbles and makes noises, softly Linda whispers that it is not only very likely, but very common. Their faces are close in proximity; the camera brings them into a close up, framing their profiles. "Love is such a strange phenomenon," she adds, "strange and exquisite." With only a few inches between them a kiss seems inevitable, until Bogart's voice grumbling, "Go ahead, kiss her" interrupts their intimacy. With his nostrils flared, mouth turned down, and eyes wrinkled Allan turns to glare at Bogart. When the moment passes, Bogart quips, "well, Kid, you blew it," even though it was Bogart's interruption, not Allan's delay, which spoiled the opportunity for a kiss.

Linda, who works as a model, expresses concern over her appearance, "When I see you with all those young women, I feel like I should be selling chocolates at Fanny Farm or something." Sitting on the couch side-by-side, Bogart urges Allan to move closer to Linda, approximately the length of her lips. Allan rhymes off sentences with a combination of the words "you uncommonly unusually beautiful." The more Allan speaks, the wider Linda smiles, and the more Bogart grimaces. "Keep talking," Linda coyly encourages, "you're saving my life. I have such an inferiority complex." When left to his own devices, Allan speaks from the heart and smoothly articulates how much he has enjoyed 
spending time with Linda. Each time Allan finally relaxes into the conversation with Linda, Bogart begins to utter pushy phrases. Bogart's interjections seem to encourage Allan's nervousness, rather than romancing.

Allan bumbles and fumbles. Suddenly, Nancy appears from behind a couch, aggressively reminding Bogart that she warned him to stay away from her husband. Nancy pulls out a gun, and with a steady aim shoots Bogart. Both apparitions leave just as quickly as they arrived. With their voices silenced, Allan finds the courage to act. He blurts out "Linda, I love you," then simultaneously kisses Linda and knocks over a lamp. Linda apologizes for knocking over the lamp, and the two wrestle on the couch while negotiating who will pay for the broken lamp. Linda repeatedly screeches, "I can't," and runs out the door. Allan begins to fear that he "attacked her," and decides that he is a "disgrace to his sex." The doorbell rings, and Allen fears it is the vice squad coming to take him away, but instead he finds a beguiled Linda, who wonders, "Did you say you loved me?"

Linda does not wait for a response, but instead kisses Allan, and the door shuts behind them. Voices silenced, a piano version "As Time Goes By" soundtracks their kissing. As their mouths awkwardly search each other's faces, the camera dizzily spins around them. Allan's fantasy of reenacting a Casablanca kiss is illuminated in the cuts to Ilsa and Rick kissing between his smooching tumbles with Linda. With the focused awe that Allan gazed at Rick and Ilsa, he now kisses and caresses Linda. Their arms gently wrap around, sliding along each other's backs. Despite the voraciousness and eagerness with which they kiss, their movements are neither awkward nor result in any fumbling. Instead, they are focused within and on each other's bodies.

The imagined Bogart is dead, and is succeeded by the image of Bogart in Across the Pacific on the poster above Allan's bed. Allan is now his own leading man, as indicated by a slow pan down from the poster, lowering to Linda and Allan lying in bed while sun pours over them. Untroubled, Allan 
suggests that Linda should tell Dick about their liaison, "Look, it happened, it happened. That's all." Allan's hands scarcely move from their relaxed position, draped over his torso, and not even the wrinkles in his forehead are suggestive of stress. With a new sense of aplomb, he adds "You felt like a woman last night, and I felt like a man, and that's what those kind of people do." As Linda wonders what their next step will be, with a calm and articulate voice, Allan suggests that she be honest with Dick and tell him that they've fallen in love to which he adds, "that is of course if you love me." Here Allan's tone is direct, as if to confirm that his feelings have not changed, rather than to seek assurance.

As the two travel up a San Francisco hill in a tram, their conversation continues, and Allan grows more confident still in their relationship. Indeed, he suggests that she move in with him. As the tram continues on its way up the hill, Allan and Linda are no longer in view, but their voices are audible through a voiceover. The city keeps hustling as the two mull over their predicament. Pensive, yet calm, Allan is certain that the right attitude will get them through the situation, "I think as long as we handle this in a mature way, as I'm long as I'm mature about it, and you're mature about it, and that both of us are mature, we can achieve a certain maturation that guarantees maturiosity." Linda follows Allan's suggestion, "Well, I think you're mature Allan, and very wise." Allan is willing to accept her compliment, and responds with a remark that is surprisingly not self-deprecating, "Well I think the key to being wise is maturiositude." ${ }^{30}$ Allan seems clear about his feelings for Linda. While walking her home, Allan bumbles only when he accidently walks into a tree placed precariously on the stairs. Their departure kiss is sweet, and Allan jokes that he'll be at home on the floor having an anxiety attack. The joke signals Allan's growth. With a bounce in his step, Allan walks away whistling and thinks to himself, "Well, she loves you kid." Greeting strangers with smiles, Allan even pats a man on the back.

\footnotetext{
${ }^{30}$ Coincidentally, Irigaray (2002) also does a little word play to emphasize maturity when she describes indirect love as "A gesture of maturity which demands a maturity capable of being on the way alone" (p. 117).
} 
Only the schlemiel emerges again, as Allan pats the man a little too hard, and he falls off a ledge.

Allan imagines the possibilities of sharing the news with Dick, each imagined scenario is aesthetically coherent with careful art direction and clever writing. Here Allan's cinephilia offers him ways of envisioning the next step. While still joyous, Allan is certain that things will work out, and that Dick would be happy to let Linda go because falling for your best friend's wife is normal, "It's a natural thing among sophisticated people." He envisions himself and Dick wearing tuxedoes, smoking pipes in a dimly lit room drinking scotch and soda. Speaking in quick succession with faux British accents, Allan tells Dick he's fallen in love with Linda. Dick dryly responds that it is just as well, since he's been given two weeks to live. Dick then raises his glass to toast Allan. Still, Dick is his best friend, and Allan does not want to hurt him. Allen imagines a broken hearted Dick, who laments having not been able to forecast them falling in love, despite his foresight to purchase Polaroid stocks when they cost only \$8.5. Dick undoes his robe, which he lets loose into the wind, before walking into the ocean to drown himself. But, Dick killing himself is not Allan's only worry. What might Dick do to Allan? After all, Allan notes, he has seen enough Italian movies to know how men behave when they have been humiliated after their wife cheats on them. Outside a movie theatre with a De Sica poster on display, Allan directs a De Sica parody starring himself and Dick as bakers, dressed in white, among carts and tables strewn with unbaked loaves. With a strange and vaguely Italian sounding accent, Dick hurls oneword insults like imbeccile, porco, and stupido at Allan while chasing him with a small blade. Allan attempts to defend himself with a limp loaf, but Dick ultimately wins by fatally stabbing him. Thankfully, Allan's real life is less scripted than his imagined life, and he surprises himself with a positive outcome. 


\section{Alvy: The film enters in as a condition of the art form itself}

Alvy's cinephilia is made visible through his way of thinking, which is rendered through the film's thinking. The use of cinematic devices such as direct address to the audience, the re-ordering of chronology, use of animation, and splitscreen suggest Alvy's control over the narrative. It is not simply that Alvy is in control of the film's thinking, but Alvy's power struggle extends to his cinematic practices. Alvy's relationship with the cinematic other is indicative of his relationship with the other.

The cinema also provides a way for Alvy to make neat, not as in Annie's sense of peachy keen, but to make clean and simple the messiness of life and love. When attending a film screening, there are established practices that can be relied upon: the film starts at a given time, and will not be late; the content of the film is at safe distance and will not impose itself; and the characters are cultured, even if suffering from psychiatric distress (as in the case of Face of Face (1976), the film he refuses to enter late at the Beekman). Unlike Alvy's rowdy family, kooky Annie, or the rest of America who looks upon New Yorkers like "left wing, Jewish, pornographers," the cinema does not embarrass, need, or judge Alvy.

Alvy is a first wave New York cinephile par excellence. Thomas Elsasser (2005) describes the first wave of cinephilia as having specific ritualistic viewing practices, "cinephilia meant being sensitive to one's surroundings when watching a movie, carefully picking the place where to sit" (p. 29) along with other ritualistic practices in a sacred setting. Alvy is particularly fussy about his cinematic practices, and like the Sontagian cinephile has particular taste in films, in this case, European art house directors. For Alvy to be a cinephile par excellence, would of course, necessitate that he would allow himself to be considered a cinephile. Regardless of Alvy's admission, his form of cinephilia implies a mastery of social codes that mark his cinephilia.

Indeed, when Annie arrives late to the Beekman Theatre, Alvy refuses to enter the cinema to 
watch Bergman's Face to Face even though — as Annie protests - the titles are in Swedish. Instead, he drags her across town to The New Yorker to see Marcel Ophul's Sorrow and the Pity, again. For Yacowar (1979), Alvy is using cinematic practices "as a means of avoiding problems in his real life" (p. 182). Where Yacowar, (1979) reads the film choice as representing Alvy's "Jewish sense of alienation" (p. 182), for Sander Lee (1997), "Alvy can't give up his rituals of pessimism and despair" (p. 71). What is a ritual of despair for Lee, I understand to be a form of comforting or pacifying. The Sorrow and the Pity becomes a metonym for Alvy's refusal to be social, and a way of retreating into the familiar. This is especially prominent when, for at least the third time in the film, Alvy wants to watch The Sorrow and the Pity again, instead of taking up an offer for a "chill evening" with Annie, and the music producer Tony Lacey, and his friends, Jack and Angelica (implying Jack Nicholson and Angelica Houston).

As the sun sets on New York, Alvy and Annie appear as two silhouettes as they walk along the shoreline. Three bridges, including the 59th Street Bridge, streak the background. His arm stiffly loops into hers. Her arms are loosely dangling as if ready to gesticulate and support her current conundrum: she's not sexy. "Unbelieveably sexy. Yes, you are. Because...you know what you are? You're-you're polymorphously perverse." Annie is clad in dusty woolen browns -save for a white high neck peter pan collar shirt --a long skirt; a long scarf; an over sized blazer; and, a broad rimmed bowler hat. The pleasure received in Annie's sensitive body is kept under wraps. She's touched by his compliment and offers back a sincere exclamation "You know what? I really like you, I mean it. I really do like you."

Alvy raises the stakes with a query: "Do you love me?" Shying away from being the only one to say it, she relies on her yeahs and giggles to carry her through the conversation. And so, Annie deflects by saying: "Do $I$ love you?" Alvy toys with Annie's hair. Annie's head bobs and nods, and she lets out a quivering series of "well... well." Alvy qualifies his question: "I know you've only known me a short 
while." Annie's voice is muffled by the lapping waves, and her pauses do not quite have the opportunity to become silences as Alvy eagerly fills in the gaps. Annie becomes giggly, and her wells have welled up into frothy exuberant series of "yeahs." Alvy voice sharpens in its annunciation and takes a silly, yet poetic tone "love... is too weak a word. I lerve you. You know, I lo-ove you, I -I loff you. There are two $f$ s. I-I have to invent...Of course, I love you." Annie continues to giggle, and quietly snorts. Her head tilts back, she rubs her nose to cover her reaction, and finally she reveals her smile. Annie tugs at Alvy's shoulders as if to show that she's finally reigned him in. Alvy leans in to kiss Annie, and Annie's hat shields their faces from the camera. She did not need to be sexy in a way that she could qualify, because to Alvy, she is something else entirely. For Annie, he seeks beyond the conventional, he invents language and he borrows terms from Freud - a vocabulary that just might be an invented language for Annie.

Rhythmic palpitations, butterflies in the stomach, and racing thoughts: excitement and nervousness are difficult to distinguish. To have understood the scene between the bridges unraveling in this way is to understand Annie as having been shy to reveal her genuine feelings and awaiting for confirmation from Alvy that not only does he find her sexy, but that he does indeed love her. Yet, it may be that as Alvy ponders on his physical attraction to his polymorphously perverse partner, he reveals feelings that had he hid from himself. If Alvy is uncovering his love for Annie through this encounter, then the scene must be rewound to enter it anew.

With their bodies close, creating a heart-shape within the frame, Alvy and Annie can sense their own excitement against the excitement of the other. Their loose hugging stabilizes them in a holding pattern of stammering swoons. Syllables crash and sneak. Annie has said that she really likes Alvy. Tilting her head down, she diverts his gaze. Alvy nervously asks "You— Do you love me?" Meanwhile, with three bridges in the background, we get the sense that the water could not keep him at 
bay, Alvy could make a break for it in any direction. Waiting to be clear, he probes again: "the key question is do you love me?" A bemused, and partly confused Annie, checks back: "do you love me?" A ping-pong play of words bounces between them, unsettling further their already nervous romance. Alvy pauses as if searching for the right thing to say. One-liners spring forth. As Alvy rhymes off potential iterations of the three-word sentence that he longs to hear, Annie giggles. Securing his own position, he emphasizes, "why didn't you think that I loved you?" Annie whispers, "I dunno." A klaxon howls in the distance. While Alvy backtracks to assume that his feelings were always obvious, he now has the security of Annie's statement. Annie perhaps did not know that he was in love with her, and she is now further confused by these nonsense words.

In addition to the ambiguity of the scene, the structure of the conversation between Annie and Alvy resembles a classic Jewish joke. One classic form of a Jewish joke is to answer a question with a question, and to change the emphasis by inflecting a different word (Rosten, 1970). If the conversation were a classic Jewish joke, it would have been spoken as follows: "Do you love me?" "What do you mean, do I love you?" "I mean, do you love me?" "Of course, $I$ love you. Why didn't you think $I$ loved you?" Like Freud's (1960) sharing of the salmon mayonnaise joke in which a gentleman borrows money in order to afford the lavish delicacy, it is unclear when expensive foods ought to be enjoyed and when one ought to reveal their feelings. ${ }^{31}$ As Freud (1960) explains "The technique of the joke lies precisely in this diverting of the reply from the meaning of the reproach" (p.50). Freud calls this form of joke displacement as it displaces the focus, "It depends not on the words but of the train of thought"

\footnotetext{
${ }^{31}$ The joke is as follows: "An impoverished individual borrowed 25 florins from a prosperous acquaintance, with many asseverations of his necessitous circumstances. The very same day his benefactor met him again in a restaurant with a plate of salmon mayonnaise in front of him. The benefactor reproached him: "What? You borrow money from me and then order yourself salmon mayonnaise? Is that what you've used my money for?" "I don't understand you," replied the object of the attack; "if I haven't any money I can't eat salmon mayonnaise, and if I have some money then I mustn't eat salmon mayonnaise. Well, then, when am I to eat salmon mayonnaise?"
} 
(p.52). In the case of Annie and Alvy, the focus shifts from love to meaning. The ultimate implication of Alvy's language remains unclear and Annie's question is never answered. Unlike the comedy of the space of the romantic comedy and the nervous romance that makes light of love, along the shoreline, Alvy's humor is still a performance that seeks to maintain power.

Where Alvy stands in relation to love is unclear. The intention here is not to condemn Alvy's wanting of security, nor to preclude him from the possibility of attaining love, but to illustrate the gravity of his conundrum. The crunching intensity of nervousness that permeates Alvy's life has created its own erotic tension, one that must be reduced if love is to be given energy.

\section{Cecilia: He's not real, but you can't have everything}

Freed from the screen, Tom's foray into the real world begins and Cecilia is on the verge of her own version of the madcap Manhattan weekend. However, Tom lives in the real world according to the conventions of the filmic world. After a lavish evening of slow dancing, dining and sipping champagne with linked arms at the Dine and Dance, Tom gallantly pays for dinner and offers the waiter a $20 \%$, no $30 \%$ tip. But his chivalry is stunted when the waiter asks if he is paying with stage or play money; it is, of course, both. In a less gentlemanly move, Tom wants Cecilia to dine and dash. He whisks her out of the restaurant and into a getaway car, but as Cecilia clarifies "this is real life, they don't start without a key." Hiding and safe in the closed down fairgrounds, Tom plans to make things right. But as Cecilia informs him it is impossible to live in the real world without money, and its the middle of the depression. Tom is tenacious, "So what, we'll have to make some concessions, but we'll live on love. We'll have each other!" A frustrated Cecilia sighs, "Oh Tom, that's movie talk."

Before Cecilia can explain further, Tom kisses her. "Was that real enough for you?" The texture of the surface and the intensity of affect affirms Tom's presence for Cecilia. In kissing him, in skimming the surface of his lips, in grazing over his skin, Cecilia apprehends that Tom is real. But, 
when Tom leans in for subsequent kisses, he pulls away confused and asks why there is not a fade out. Classical Hollywood film thinking would render this moment, as Tom explains, with a fade out that would allow them to "then [make love] in some private perfect place." Tom follows the logic of a love of unity, assuming that their union brings happiness, and that happiness is what matters above all else. Despite her naïveté, Cecilia is grounded in the material reality of the depression era and her own depressive circumstance. Cecilia is aware that neither unity, nor marriage brings happiness. Tom may be a real presence in Cecilia's life, but he lives according to the logic of the movies believing that happy endings are the only ending. The Hollywood leading man may be daring, dashing, and romantic, but in Tom's instance, without the context of his world, Hollywood cinema, he is a fish out of water.

If the medium of the image's appearance determines the logic of its existence, then we might go on to say that the limits of life and love are determined by the medium of our existence. Tom seems to understand this to a certain extent, and understands why Cecilia is hesitant about leaving Munk for him, "You're married and you're old fashioned, and I'm a new idea." The ontology of this double is determined by the media. He is a fleshy copy, with motivations and intentions based on his experience in the reel; or, as Tom says of himself, "its been written into my script."

The writing of Tom's script and the fleshing out of his presence is a source of tension for those around him-except, of course, Cecilia. Raoul Hirsch (Alexander Cohen), the director of The Purple Rose of Cairo fears that other Tom Baxters across the nation will start to step out of the screen. The Jewel's manager (Irving Metzman) is uncertain what to do with the projector. Gil Sheppard, the actor who performed Tom Baxter, is both flattered and fussed by his double. Gil is quick to assume responsibility for Tom: "I created him," he tells Cecilia. "Well, didn't the man who wrote the movie do that?" she asks. Gil responds: "Yes, technically. But I made him live. I fleshed him out." This pun reveals Gil's ignorance and his arrogance in assuming responsibility for Tom's flesh. It is precisely Gil's 
flesh that his agent is concerned with: "This is the scandal of a lifetime. You know what happened to Fatty Arbuckle's career?" They all decide that Tom must return to the screen.

With the protagonist gone from The Purple Rose of Cairo, the other characters are uncertain as to what to do and converse among themselves. Henry asks: "Why are you people here? We can't do anything until Tom gets back." Staring out into audience, Rita, bored, notes: “They don't look like they're having fun to me." Though a 'minor character', as the socialites like to remind him, Tom's role as the explorer of the expedition moves the story, and without him the story stalls. Worse still, the characters cannot agree on what the story is about. The theatre patrons become annoyed, "Look at this, they sit around and talk, and no action, nothing happens." Another yells "I want my money back. This is outrageous." The countess becomes impatient with their complaints, and snipes at the patrons. When a patron's husband comes to his wife's defense, the Countess shouts, "I'm a genuine Countess with a lot of dough, and if that's your wife, well... she's nothing but a tub of guts." The tub of guts, of course, is more genuine than the genuine countess. The confusion between who is real, and of what consequence their reality is becomes a problem as Cecilia and Tom's relationship develops, and Gil begins to intervene.

\section{Mickey: Do you realize what a loose thread we're all hanging by?}

As Mickey tells his assistant Gail (Julie Kavner), “I’ve gotta get some answers, otherwise I'm gonna do something drastic." The drastic measures that Mickey takes are told to Holly, and are revealed in a flashback sequence after he has already come to terms with the absurdness and silliness of life and love.

When Mickey's religious seeking is not working, he resorts to buying a gun. Distraught and fed up with his search, Mickey, shivering, holds the gun in his hands. His profuse sweating loosens his grip on the gun, and it accidentally goes off, shooting his mirror. The noise worries the neighbours, who 
pound on his door and ring his bell to inquire about his safety. Mickey had not anticipated that the gun would go off, neither had he anticipated the pandemonium of people coming to his rescue. Stunned and seeking clarity, Mickey decides to get some fresh air to clear his head and walks the streets of New York. Mickey's wandering lasts for hours, traversing the Upper West Side. He explains to Holly that he needed a moment to gather his thoughts, to be logical, and to "put the world back into rational perspective," so he enters the Metro movie theatre. Duck Soup (1933), a film that he has enjoyed several times before, is playing. Sitting in the velvety chair in the darkness of the matinee, Mickey's stirring emotions begin to settle. On-screen the song-and-dance number "We're off to war" commences. Groucho Marx uses wooden mallets to rhythmically tap men's helmets, and irreverently celebrates the devastating news. Having sought answers that would transcend him to something larger than himself, Mickey is taken beyond his immediate heart palpitating, sweating, trembling to coexperiencing the contagious joy around him. In a room full of delighted cinephiles giggling at the zany antics on-screen, Mickey describes himself as getting "hooked on the film" and asking, "Don't you want to be a part of it?" Focusing on the silliness on-screen, Mickey becomes attuned to the vibrancy of life pulsating around him. Finding the joy in just being part of it, Mickey admits he began to "sit back and enjoy [himself]." The Marx Brothers lend their comedy to the space of the nervous romantic comedy. Their light-hearted, wacky humor is antithetical to Mickey's morose mood. Here the physical space of the cinema shelters Mickey from the outside world of chaos, but also the joy at the emotional core of the Duck Soup (1933) facilitates Mickey's embodied reconsideration. Letting go of his quest for answers, Mickey becomes conscious of the simple wonders around him.

\section{Anxiety or homosexual panic?}

In the midst of a wave of intensity, Linda asks Allan for some pills. In order to properly assist her, Allan asks her to diagnose the issue. Linda lists off symptoms including a throbbing headache and 
chest pains. As Allan searches for the right pill, he notes that in his case this could correspond to anxiety or homosexual panic. The nervous romantic demonstrates a keen attunement to their body. However, the way that they interpret these sensations poses an obstacle. The nervous romantic's attunement enables them to be aware of the discomfort a love of unity posed. Their awareness of bodily experience is indicative of their ability to decipher their perceptions and sensations, and how perception and sensation corresponds to emotion. However discriminating the nervous romantic is between their sensations and emotions, the theoretical and practical distinctions between affect, sensation, and emotion are not clear. As Massumi (2002) states "It's simply this: sensation is never simple" (p. 13). Affect, for Massumi (2002), is to the body as energy is to matter; affect is a precognitive intensity, and emotion is the socially negotiated narrative of the sensation. For Seigworth and Gregg (2010), and Lawrence Grossberg (1992) affect is understood as a felt intensity in the body, a sensation which does not necessarily carry meaning, but can have meaning affixed to it. Affect communicates, but what it communicates is a given strength of bodily experience. Emotion is affect with signification (Seigworth \& Gregg 2010; Grossberg, 1992). For the purposes here, affect will be understood as the movement between bodies that is registered in sensation, sensation is the intensity registered in the body, and emotion is the narrative that explicates affect and sensation. Affect, sensation, and emotion are enfolded in each other, as each is a movement before becoming the next. These definitions correspond to the phenomenological uses of perception, sensation, and auto-affection, where each is an awareness of what is happening both inside and outside of the body. This is of particular importance to understand the role embodiment plays in the relationship with the other. As will be further explicated in the next chapter, for Jean-Luc Marion (2007) awareness of the other is as a crossed-phenomenon during which intensity arises in the body, but at the same time that the mystery of the other is preserved; similarly, for Luce Irigaray (2001) perception is a way of accessing the other as other, which both originates and 
returns to the body.

The experience in the cinema does not dismiss the fear and nervousness of the nervous romantic. Rather, the emotional assumptions of their sensations of the other are recontextualized in their experience through an encounter that is comfortable for them. The cinematic other overwhelms the nervous romantic — an experience they understand and assume to be positive. The nervous romantic must remove the horizon of expectation from the other, and be open to receiving the other. The cinema offers a site of practice to receive the other without controlling, possessing, or distancing the other.

\section{The Experience in the Cinema}

In the previous chapter film phenomenologists Merleau-Ponty, Sobchack, Frampton and Laine were referenced in order to position the cinematic experience as embodied, and to set up the relationship with the cinema as an intersubjective relationship with an other. Phenomenology considers the cinephile's relationship with the screen as a co-presence of intersubjectivity. As a with-ness to cinematic reality, the body is engaged in understanding and perceiving the reality of the cinema. How might this experience be described?

The embodied experience of the cinema takes on a meditative quality, in which contemplation is matched by the register of bodily affect at the fore of the experience. Indeed, this may be understood as a variety of perception that has been practiced or cultivated. Meditation is not simply a focusing of thought, nor the mediation of feelings toward things outside of the body, nor cultivating a sensory awareness that takes one out of their body. Rather, meditation is a cultivation of sensory perception that can attune a person to an enhanced experience of their own body. Such an embodied relation can also be described as a form of auto-affection, as the body feeling itself feel. The difference between meditation and auto-affection is that where auto-affection is an automatic, unprepared feeling of the body feeling itself feeling, meditation is cultivated through practice. 
Since cultivating perceptual relations is not part of the Western way of relating to the world, Irigaray (2002) argues "we are accustomed to living thought as a night of the senses, as a transmission of language and its truth, without putting either of those to the test of everyday perception" (p. 22). Irigaray's $(1996 ; 2002 ; 2008 ; 2013)$ texts draw upon Hindu sutras of meditation and yoga practice that have come to inform contemporary practices of Iyengar and ashtanga yoga, though she does not name these practices outright. Irigaray (1996) writes of yoga traditions in which the "body is cultivated to become more spiritual and more carnal at the same time" (p. 24) through diet, training the senses, breath work (pranayama), and a respect for natural cycles (day/night, the changing of seasons, and the progression of time). ${ }^{32}$ This training brings the body into presence with its immediate surroundings and its multiple functions. As will be further elaborated in the following chapter, meditation as a form of cultivating an awareness of auto-affection is a pre-condition for accessing and maintaining a love of letting be because it grounds the lover in their own experience. Auto-affection must be preserved when "an attraction for the other takes a part that will be a source of emotion but also of movement on the condition that one also dwells in oneself" (Irigaray, 2008, p.100-101). The cultivation of auto-affection returns us to our bodies, it helps us be "[faithful to ourselves] and to respect the other in their singularity, reciprocity in desire and love- more generally, in humanity" (Irigaray 2013, p.162). ${ }^{33}$ Irigaray (2001) also critiques male philosophers - in particular Sartre - who set up love as an

\footnotetext{
${ }^{32}$ In his La Lyrosophie (1922[2012]) Epstein compares the experience of the Kabbalist who takes the universe into themselves in order to learn about the universe to the experience of the cinema. For both, knowledge comes from a unified plane of feeling that disrupts the differentiation between the subjective and the objective. See the newly translated version in Jean Epstein: Critical Essays and New Translations (2012) for details.

${ }^{33}$ Christophe Wall-Romana (2012) reads a similar process of relating to the body in Epstein's theory of photogénie. "I would propose that photogénie implies a particular mode of scopophilia whereby the apparatus concentrates and reflects back optical desire in a way that discloses the spectator's body as sensorially self-relating - sensing itself viewing - through the 'enactive' aspect of filmic images" (p. 61). For a further discussion of the bodily relation in photogénie see his text "Epstein's Photogénie as Corporeal Vision" in Jean Epstein: Critical Essays and New Translations.
} 
"impossible ideal" in which "the transcendence of the other is to be possessed as pure transcendence inaccessible to the sensible experience, but nevertheless as a body" (p.17). She also critiques MerleauPonty for over-looking perception "as a means of acceding to the other as other. Perception represents a possible path for sensing the other, respecting him as a subject, and it also allows me to remain a subject while perceiving the other. Perception can establish a link between the reception of a face exterior to me and an intention towards the world, towards the other" (Irigaray, 2001, p. 22).

Perception is the word that Irigaray uses in order to address the inter-relation between two that can be cultivated. Here is it essential to note the nuance between auto-affection and perception. Autoaffection is an automatic arising of perception, which can be cultivated by meditation and cinematic practice. Perception is "being attentive to the qualities both of what is perceived and of the other who perceives" (Irigaray, 2001, p. 41). For Irigaray (2001), it is essential not to confuse perception and sensation. Sensation "always wants to grow in intensity" (p. 41); sensation "remains more blindly passive in what is felt, and does not discriminate between dream, artifice and what is real or true" (p. 44) and leads to a forgetting of one's self, which leads to fusion and to unity. Following Irigaray's argumentation, the dangers of Cecilia's kiss with Tom becomes evident. The intensity of their kiss seeks only more intensity, to be making love in a perfect place, but does not withdraw in perception to be aware that Tom is an image. Since sensation does not return the self to the self, the way that perception does, there is a risk of "reducing the other to sensations... to take away their subjectness"' (Irigaray, 2001, p. 40) [original punctuation]. Perception maintains distance, and recognizes the enigmatic, unknowable nature of the other. As Irigaray (2001) explains "to perceive you through the senses, leaving you an extra cloud of invisibility. I perceive you, but what I perceive is not the whole of you, and the whole of me is not perception" (p. 46). Cultivating perception is cultivating the awareness of interiority and exteriority that is auto-affection, and that comes to form intersubjectivity. 
Understanding the role of perception in intersubjectivity is essential in order to appreciate why a love of letting be must follow an erotic rationality, as will be explicated in the following chapter.

The cinema, as the space of the nervous romantic, permits a momentary transcendence of the immediately persona of nervousness, in that it orients attention simultaneously inward and toward something outside of the self. In the cinema, our full embodied attention, not only our vision is activated. To emphasize Epstein's (1998 [1921]) point, we "breathe its radiance" (p. 238). As Vivian Sobchack (2008) writes, filmgoers "have always made sense of the cinema (and everything else) not only with their eyes, but with their entire bodies" (p. 194). The experience in the space of the nervous romance, to paraphrase Vivian Sobchack, makes sense because it has sense. The magic of the movies provides the site of transformation toward manifesting a changed relationship to love.

It should be noted that in using words to translate body experience there is already a sort of failure. This failure begins with the limited vocabulary for describing embodied experiences, and for modes of perceiving, where perceiving is understood to be implicated in cognition, through the body. To speak of an illumination or enlightenment is to comically envision a light bulb coming on in the mind of the protagonist who has suddenly had a realization. Isaac's jaw-dropping gape at Tracy during the final moments of Manhattan is such an image of realizing the bright side; however, Isaac's face here serves as a metonymy for his reaction, precisely because his face is most expressive without relying on language. To focus on the relaxing of tension in the musculature in Isaac's abdomen, or the shifting in his gait, or through cinematic device to reveal the decrease in his heart rate and blood pressure would serve to better indicate Isaac's bodily changes; however, these close depictions of the body shift the focus of the film's thinking away from the exchange between Isaac and Tracy. Further, metaphors such as thinking through the body return to the mind and re-route experience as cognitive. The goal here is to remain in the body, to remain within the vitality and the vibrancy of the body. 
The body becomes literally enlightened through the experience in the cinema, in that it begins to feel lighter, not clenched or deciphering, as Allan does, the pangs of what is either anxiety or homosexual panic. Given the sensitivity and the precision with which the Allenesque character can already distinguish between their embodied responses it might not be an exaggeration to ask them how particular body parts, the spleen for example, feels when they are in the cinema. Such acute awareness is inessential as this inquiry seeks only to understand if the fear, panic, nervousness, anxiety, or fury of feelings that accompany the response to a potential lover are transformed. The intention is to understand how the cinematic other facilitates an alternative response to love.

For the cold feet of the nervous romantic who is not only seeing, but experiencing the world anew through the body, a loving approach to the world is awakened in the captivating space of the cinema. André Bazin (2005c [1969-1971]) echoes this experience, "In my opinion, the cinema more than any other art is particularly bound up with love" (p. 72). The sensory experience in the cinema will become the focus of understanding how cultivating sensory perception will enable an embodied intuition of love as letting be. The meditative quality of the embodied experience in the cinema is pivotal in apprehending a love of letting be that follows an erotic rationality, a bodily logic, which requires an awareness of bodily cues and the nuances of bodily affect. The next chapter will further elaborate on the erotic logic of the phenomenon of love and the role of cultivating perception. 


\section{Chapter 5: \\ Opening to love in the cinema with Woody Allen}

"The most beautiful words in the English language aren't "I love you" but "it's benign." Deconstructing Harry

In the previous chapters a phenomenological approach to the cinema was outlined, and cinephilia was introduced as a perceptual relation to and with the screen. In this way, cinema offers the conditions to begin to understand the indirect love of non-unity characterized by letting be. This chapter will illuminate the role of body, its affects and sensations, in coming to a love of letting be.

\section{The Love of the Cinephile}

Cinephilia is a term that has been used to describe various cinematic viewing practices and rituals. A cinephile is commonly understood to be a master of information about the cinema. Marijke de Valck and Malte Hagener (2005) describe cinephilia "as an umbrella term for a number of different affective engagements with the moving image" (p. 14). And, Thomas Elsasser (2005) describes the first wave of cinephilia as having specific ritualistic viewing practices, "cinephilia meant being sensitive to one's surroundings when watching a movie, carefully picking the place where to sit" (p. 29). The importance of getting the right seat is carried through to Frampton's (2006) reference to the cinephile's seat. The cinephile discussed here is not simply infatuated by the ritual of movie-going, or collecting artifacts and trivia. Rather, this cinephile is tasked with approaching all forms of love from a stance of non-unity with a love of letting be. This cinephile cultivates a relationship with the screen, and a loving approach to the world is awakened through the captivating power of the cinema.

Similarly, André Bazin has written on the transformative power of the cinema to arouse love. For Bazin (2005c [1969-1971]) the cinema-in this instance the cinema of Vittorio De Sica specifically — is inextricably linked to love: "In my opinion, the cinema more than any other art is 
particularly bound up with love" (p. 72). Revising Bazin slightly, Robert Sinnerbrink (2013) writes: "In its best instances, the cinema, ... more than any other art is particularly bound up with lovethat sensuous love of the world, a belief in its reality, that we have forgotten or lost" (footnote 46) (p. 100). Sinnerbrink (2013) thus draws out Bazin's emphasis on the selection of the film, the experiential or sensuous experience of the cinema, and the revelation of the world that film can offer. These three elements: selection, sensation, and revelation make up the matrix of a Bazinian cinephilia for Sinnerbrink. This suggests that not every film interacts or intends to interact with the cinephile in the same way. Indeed, despite the breadth of films the nervous romantic has enjoyed, there are particular films that they are drawn to: Allan's fascination with Bogart attracts him to Casablanca, Alvy insists on rewatching the Sorrow and the Pity, Cecilia's fifth viewing of The Purple Rose of Cairo brings forth Tom from the screen, and Mickey is struck with joy after re-watching the Marx Brothers' Duck Soup.

Cinematic meditations are a sensuous response to reality. In writing on De Sica, André Bazin (2005c [1969-1971]) emphasizes "the love De Sica bears for man" (p. 73) and his "language of reality" that "only love can utter" (p. 69). De Sica offers "sensual or sentimental attention" (Bazin, 2005c [1969-1971], p.72) to the world. De Sica's neorealism is not simply an aesthetic triumph, but an ontological one. Neorealism's "simple appearance of beings and of the world" (Bazin, 2005c [19691971], p.65), Bazin pronounces, "is a phenomenology" (2005c [1969-1971], p.65). The aesthetic creates an entire world. Bazin's concern with De Sica and realism is the technological and stylistic achievement of belief. As Dudley Andrew (2004) explains "Bazin is often prematurely accused of being a proponent of a realist style. However, realism to Bazin is not primarily a stylistic category, it is an automatic effect of photographic technology drawing on an irrational psychological desire" (Andrew, 2004, p. xv). For Robert Sinnerbrink (2013), "Bazin's concern with realism, rather, is more engaged with the psychological and existential needs that the image serves" (p. 99). Realism is the 
aesthetic condition for the cinema to make us believe. And it is the question of belief in the cinema, to paraphrase Sinnerbrink, which is a Bazinian cinephilia (2013, p. 96). Belief in the reality of the cinema allows the cinephile to respond to reality with love. This belief is embodied, not simply cognitive. Thus, the cinematic experience invites the cinephile to open themselves to a new embodied engagement with the world, an engagement characterized by love.

For Bazin (2005a [1967-1971]), it is "[only] the impassive lens [objectif], in stripping the object of habits and preconceived notions, of all the spiritual detritus that my perception has wrapped it in, can offer it up unsullied to my attention and thus to my love" (p. 9). The cinema alters our habituated ways of looking at the real world, and some films, as Vivian Sobchack (2011) points out, question not only our natural attitude when looking, but what we might call our 'naturalized attitude'. The power of the cinema, for Sinnerbrink (2013), is the power "to reveal reality a new; to alter our habituated perception and thus transfigure our experience (to offer it to our love)" (p. 100). This re-vision of looking complements the meditative experience in the cinema since it directly acknowledges, at least in part, the transformation of perception. As articulated in the previous chapter, while auto-affection is automatically arising, perception is cultivated through practice or through repetitive cinematic encounters. While the cinema invites the cinephile to regard the world with love, the cinephile must practice attuning themselves to both their own embodied experiences and the experience of the cinematic other. In sum, cinema is more than a space or an artform, but a way of apprehending the world with love. It is not only that the world is apprehended with love, but we must task ourselves with loving the world as it is, a task upheld by the cultivation of perception.

\section{From I Loaf You to I L-L-Love to You}

The stammering and invention of language is Alvy's attempt at articulating his feelings, feeling of uncertainty and anxiety. Part of the anxiety that Alvy experiences around love is due to 
understanding love only as unity or fusion, which for him signals the death of individuality. Alvy fears Annie moving in because it takes away his life raft: Annie's crummy, buggy apartment with the bad plumbing. Interior's Arthur recognizes that Eve has frozen, if stolen completely, his individuality. The overbearing presence of Eve's earth tones and neutrals throughout every mise-en-scene manifested in clothing, accessories, and decor is suggestive of the burden of her influence not only on Arthur, but their daughters. What Alvy fears most of all is what Arthur is trying to escape: a relationship wherein lover and beloved are not only joined together, but in which they become indistinguishable. Lover and beloved are like the circular humans of whom Aristophanes speaks of in Plato's dialogue, humans who would rather starve than be separated. As previously mentioned, the union of lover and beloved is still valorized by, what is assumed to be, the happy ending: the unification of the couple

Allan struggles to envision himself as a lover, or even as someone that women would be attracted to. Cecilia hides in the movie theatre for reprieve from her sad life with Munk. And, Mickey is wrapped up in his career, and his desperate search for answers. Where Alvy fears unity, Allan and Cecilia struggle with seeing love as a possibility for themselves, and Mickey is caught up in a vain search for meaning. All of the nervous romantics seek the validation that someone does love them. To begin loving from a place of seeking the security of love is already to be caught up in seeking out a love of unity.

A love that unifies two beings is not the only option available, neither philosophically nor practically. There is a love of non-unity, a love that understands two beings as complete, unique, and irreducible. In a love of non-unity, a lover recognizes their significant other as other. The presence of the lover, does not denigrate the other to beloved, but they can remain a lover. A love of non-unity occurs between two lovers. These two lovers encourage each other to develop into themselves. The process of supporting the lover to become themselves involves letting be. Letting be does not imply 
that the lover is left to their own devices, nor does it imply that the lover is not concerned for the other lover. A love of letting be is not indifferent. On the contrary, to let be is to support the lover in their difference and to nurture a relationship with the self. Central to cultivating a love of letting be is an attunement with auto-affection that indicates a faithfulness to perception which both returns the lover to themselves, and maintains a distance from the lover.

The foundation of a love of letting be is found in the work of Luce Irigaray and Jean-Luc Marion. Marion and Irigaray both work to return the wisdom of love to philosophy. Their theological foundations are different, Marion studied intensively with Jesuit scholars, and Irigaray cites Hindu scripture and has studied with yoga teacher Krishnamancharya. Their spiritual interests, which are inflected in their phenomenology of the other are superseded by their concern with ethics, and more importantly with love. ${ }^{34}$ Both develop a phenomenological account that owes much to the concept of the other in the work of Emmanuel Levinas. ${ }^{35}$ Both understand the other as unknowable, as always beyond comprehension. Both agree that the other's otherness must be preserved as a mystery. Love must work to sustain this mystery, and not reduce it to the bodily or to the bawdy, as mere desire. Both acknowledge non-reciprocity in love, and the violence that the response to a love of unity demands, that saying I love you, assumes the response I love you, too. For both, a loving relationship requires a commitment to continually learning about the other, to performing endless hermeneutics (Marion, 2007) and asking "Who are you" (Irigaray, 1996, p. 119).

The intersubjectivity of the subject's relationship to the other, as described by the filmphenomenologists, is akin to the intersubjective relationship between lover and lover; however, it cannot be overstated that the relationship between lover and lover is asymmetrical. The lover always

\footnotetext{
${ }^{34}$ This is especially true in the case of Marion, for whom love as "superior to ethics, since it allows for an individuation of the other than ethics cannot accomplish" (Geschwandter, 2007, p. 232).

${ }^{35}$ In the work of Emmanuel Levinas, Other is typically capitalized. In order to remain consistent with Irigaray's use, I will continue to use the lowercase other.
} 
exceeds our understanding and we must always work toward holding space, maintaining difference, to preserve their alterity. Marion (2007) refers to the other who is not reducible to perception, but instead is to be conceived of as excessive. Marion (2002) insists that the " other must remain invisible so as to offer himself to a possible love, because if by chance, I saw him (if an intuition adequately fulfilled the intentional object), he would ipso facto already be disqualified as other" (p. 80). Seeing in this context implies gaining visual knowledge from the encounter with the other. In his earlier work, Marion has described the other as a saturated phenomenon ${ }^{36}$ who is in excess of my perception, and who overwhelms my capacity for categorizing them as an object of knowledge. Thus, the other is always beyond my reach, and unlike the other of Hegel and Sartre, cannot be known, dominated or subsumed. Both Marion and Irigaray work to maintain the mystery of the other through indirection: Marion writes of the crossed phenomenon, and Irigaray writes of space and silence that safeguard the other.

Since the other is a mystery who eludes knowledge, the experience of encountering the beloved is a crossed phenomenon characterized by indirection. Marion (2007) describes the crossed phenomenon as "two intuitions fixed by a single signification with a double entry point" (p. 105). The crossed phenomenon is the meeting of the two saturated intuitions who do not have any intentionality toward each other, "the two gazes cross each other in an exchange that preserves the distance, and yet they both appear mutually to each other through their significations" (Geschwandter, 2007, p. 234). The crossing is an oblique encounter during which the intuitions signal to each other, but they do not serve as intentional "poles" toward which the other must move. Indeed, the other must be preserved from becoming a kind of intentional pole. In this way, the relationship between intuition and intention becomes stretched to the breaking point. In sum, the erotic phenomenon as a crossed phenomenon is excessive and overwhelms the horizon of phenomenality.

\footnotetext{
${ }^{36}$ The saturated phenomenon is elucidated in Marion's earlier works. A saturated phenomenon can be understood as a phenomenon that cannot be maintained by a horizon, and overwhelms our intuition.
} 
Similarly, for Irigaray (2002), "the other is the one toward whom we advance in darkness" (p.155). The other needs to remain hidden, by "remaining hidden, the other can be safeguarded" (Irigaray, 2002, p. 154). Irigaray (1996) works toward a recognition with "respect for what is, for what exists" (p.106). To recognize the other is to recognize their transcendence. The other is beyond me, and I must "halt before you as before something insurmountable, a mystery, a freedom that will never be mine, a subjectivity that will never be mine, a mine that will never be mine" (Irigaray, 1996, p.104). Irigaray also phrases it this way: "the desire to love is like a veil which keeps a mystery" (Irigaray, 2001, p. 47). In order to safeguard this mystery, Irigaray advocates for silence and space which are part of cultivating the auto-affection necessary to maintain an indirect love. Silence and space create a "barrier against alienating the other's freedom in my subjectivity" (Irigaray, 1996, 110); silence and space are an "attempt to avoid falling back into the horizon of reduction of the subject to the object, to an item of property" (Irigaray, 1996, p.111). The preservation of subjectivity, like the preservation of mystery, and the safeguarding of space all serve to protect against fusion and unity: they are the 'life raft' that Alvy seeks.

The relation of letting be is summarized, for Irigaray, in the statement "I love to you." "I love to you" works to "define a relation of indirection between the genders in which we overcome the obstacles posed by relations of appropriation or of fusion between persons and by replacing intersubjective relationships with instrumentality" (Irigaray, 1996, p. 108). ${ }^{37}$ The linguistic separation of I and you with the preposition "to" performs a relational separation as well. "To" enacts and preserves a space between I and you. The space of the "to" is silent and cultivates listening. Irigaray (1996) describes silence as the primary gesture of "1 love to you." In this space of the "to" we must listen, and simultaneously we give the other an opportunity to manifest themselves to us. To maintain

\footnotetext{
${ }^{37}$ Irigaray's project intends to establish a feminine subjectivity based on feminine experience, to define woman on her own terms, in order to build a world of two genders.
} 
the space of the "to" Irigaray (2001) now emphasizes a return to the self: "One must love enough to generate and not wound: love the other as a whole, love him in his life without giving him one's own" (p. 12). This return to the self cultivates the silence and is "offering you an opportunity to be you " (Irigaray, 2001, p. 15). In this space we must continually ask ourselves about our relationship to the other: "Thus: how am I to speak to you? And: how am I to listen to you?" (Irigaray, 1996, p. 113). The other is a mystery, and we must preserve that mystery, and continue to ask: "Who are you? You who are not nor will ever be mine?" (1996, p. 119). The "to" facilitates the indirect love to let the other be. It preserves the differences of each lover, while allowing them to work together.

A love of letting be prioritizes love over ontology, and in doing so protects against reducing the lover to a beloved and the fusion between lover and lover. For Marion (2007), the lover must overcome their ego, to become the ego amans. The ego amans is given in love, but also loves without expectation of reciprocity. As an ego amans, the lover is unlike the modern autonomous agent, like that of Hegel or Sartre, who relies on the other for self-identification and seeks union. The ego amans is a subject given in love, in other words, the love of the other grants the ego its being.

The role as a lover does not begin when the lover encounters the lover, but requires some preparation for the lover to develop an embodied awareness of themselves. For Jean-Luc Marion (2007) love follows an "erotic rationality" (p.5), where erotic implies of the body. Embodiment is not simply understanding oneself as auto-affectionate, as a feeler who can feel themselves feeling, but is as the heart of performing the erotic reduction in which one recognizes themselves as a lover, the ego amans. The removal of expectation around reciprocity is called the erotic reduction. For Claude Romano (2007), the erotic reduction "Would be love, purely and simply, suspending every requirement of reciprocity. He who has accomplished the erotic reduction loves truly (or is capable of doing so), while he who has not accomplished it remains caught in the logic of exchange, and thus does not even 
attain to this possibility" (p. 330). The ego amans overcomes the ego's desire for certainty and reciprocity. Prior to the erotic reduction and the production of the ego amans, the ego reacts out of vanity and insecurity. As Marion (2007) explains "assurance as always already lacking, from my needy ego, struck with panic before a shortage and directly taking refuge behind reciprocity" (p.70). The ego's neediness and vanity poses a threat to love:

The obstacle that obstructs the opening of the amorous field--an erotic obstacle, not an epistemological or ontic one--consists in reciprocity itself; and reciprocity only acquires this power to set up an obstacle because, one assumes, without proof or argument, that it alone offers the condition of possibility for what the ego understands by a "happy love." (Marion, 2007, p. 69)

Reciprocity as a condition of love, sets up love as a kind of exchange. Instead Marion suggests that love itself must be loved, and love must be given out at a loss. We must not ask, as if anyone out there loves me, but instead ask: can I love first? (Marion, 2007).

Unlike the pessimistic forecasting of anxiety, the future of a love of letting be is not anticipated, but cultivated in the present. For a future in which each lover fully gives each other the opportunity to let themselves be fully, the cultivation of a perception, the change in perception happens before we encounter the other. Marion (2007) deems this the lover's advance. The lover's advance is not a tactical movement forward, as the name may suggest. Rather, the lover's advance is what happens before, in advance, of encountering the lover; it is how the lover prepares to encounter the lover. The lover's advance is what they do in advance.

Loving without the assurance of reciprocity is of particular difficulty for Alvy who asks "Didn't you think I loved you?" and Allan who cannot quite settle himself down long enough to realize that he need not trick or convince a woman to love him. What the Allenesque character needs to understand is that in choosing to love, they have already succeeded. Success is in loving love:

In the erotic reduction, if one truly wants to win, it is necessary to love and to persist in this advance, without condition -thus the last to love wins the stake. What stake? To love, of course. 
The winner is--the last lover, the one who loves to the end. For the lover loves to love. (Marion, 2007, p. 87)

The body of the lover is eroticized, and made flesh by the other lover. To be made flesh is to be receptive of pleasure from the other; it is to be given what one cannot give, but neither what one can take away. Eroticism serves to awaken the flesh, and the flesh of the other; without this form of carnal knowledge, "Contemporary eroticism slides inevitably into solipsism, an eroticism without other" (Marion, 2007, p. 159). To eroticize the flesh is to "make possible an experience of the flesh that is not a possession but an opening" (Marion, 2007, p. 136). Through the experience of flesh, the ego amans is receptive to the mystery other and the task of protecting mystery. Thus, eroticization is the body as experienced by a lover, who must still respect the mystery of the other.

Where Marion emphasizes the eroticization of the body as central to the erotic reduction, Irigaray (2002) emphasizes auto-affection as central to observing and maintaining the distance that enables being two: "an encounter between two different subjects implies that each one attends to remaining oneself. And that cannot amount to a simple voluntarist gesture but depends on our ability for 'auto-affection'” (p. xiv). Irigaray (2002) goes on to explain that auto-affection is essential to our relationship with otherness: "Without [auto-affection], we cannot respect the other as other, and he, or she cannot respect us" (p. xiv). The ability to be present in the body with feeling oneself feeling brings awareness to the space before the other. Faithfulness to oneself "is indispensible for a meeting with the other, a dialoging with the other, a loving with the other. Without it we fall back into fusion, or into couples of opposites whose relation will be governed by hierarchy, submission of the one to the other, sado-masochism" (Irigaray, 2002, p. xv). Auto-affection is a return to the body that brings the awareness of the body, and the role of the lover, into focus along with the difference of the other. The function that auto-affection, and implicitly meditation, has in preserving the mystery and the space before the other cannot be overstated. 
Throughout her works, Irigaray (2013) emphases auto-affection as "the basis and the first condition of human dignity" (p. 61). In order to illustrate the role of auto-affection, Irigaray (2006) uses the example of the Buddha contemplating the flower, but not picking it. It is important to recall that contemplation is implicit in the practice of auto-affection. "Contemplation is also a training in finding pleasure while respecting what does not belong to me" (Irigaray, 2006, p. 24). Cultivating autoaffection maintains difference. For Irigaray, this form of cultivating thought and sense perception has political implications that work against female oppression and the patriarchal forms that determine family units and the functioning of capitalism. ${ }^{38}$ Such a political project is beyond the scope of my work here which intends solely to comment on a loving encounter characterized by letting be that is available outside of spiritual training. Nevertheless, Irigaray's point is well taken: noticing and cultivating auto-affection attends to our participation in the safeguarding of the other. If we seek a love of letting be, then we must learn to withdraw into our bodies in order to become more aware of autoaffection to preserve what is.

The transformation of the nervous romantic does not occur in a grand gesture, but rather is slowly realized through a nuance in action. This is perhaps best explained by Marion (2007) who describes the experience of realizing that someone is in love like the experience of a runner winning a race. The moment one realizes they are about to win, they do not stop running, but they continue to move with speed toward the finish line with the feeling of winning arising throughout their body. Unlike winning a race, the completion of love is a horizon that continually slides further away.

\footnotetext{
${ }^{38}$ In Sharing the World (2008) Irigaray continues her earlier work on the difference in experience between men and women's auto-affection. Women's self touching is essential to Irigaray to understand feminine subjectivity as divided. For her, there must be respect for the two different subjectivities in order to come to co-create a world that recognizes the distinction of masculine and feminine subjectivities.
} 


\section{Allan: She's a Real Tomato}

Just as Allan envisions imaged responses, he is confronted with Dick's real response: Dick is jealous. Allan arrives home to find Dick waiting for him on his doorstep. Uncertain of Linda's whereabouts the previous eve, he flew home to check in on her. Dick confides in Allan that Linda talks about an affair in her sleep. The only name that Linda mentions is Allan's, still Dick assumes Linda's lover must be someone he does not know. Dick fears that as a result of his neglect, he has "lost her to some stud." Having realized the error of his ways and that without her life is not worth living, he decides he wants to take care of her. In listening to Dick, Allan decides that he cannot break up their marriage and must hide their affair from Dick so as to not upset him.

Just as Dick arrives home to confront Linda, Allan decides he must get in touch with her to warn her and to tell her about his change of heart. When the phone rings, Dick demands to know who is calling. "Is that him?" he asks. Linda shyly responds, "This is Allan", and hangs up the phone. The gag continues as Allan repeatedly attempts to call Linda, and his fingers struggle with the dial on the rotary phone. Even as Linda indirectly confesses that she has made love to Allan, Dick is not able to see Allan as a viable lover.

Allan is determined to set things straight between himself and Linda, and rushes over to their apartment. As he runs up their outdoor stairs calling for them, a kind stranger tells Allan, "If you're looking for the Christies, they just left for the airport." Allan jumps in a taxi to intervene at the airport. The taxi driver is none other than Bogart. Allan is not yet able to recognize that he has become his own 'Bogart'. Bogart assures Allan that he has indeed become his own 'Bogart', "Everybody is at certain times. You're doing something now that I didn't think you had in you. You're passing up a real tomato because you don't want to hurt a guy. If I did that there wouldn't be a dry eye in the house." Without bearing witness to his own transformation, or having time for self-reflection, Allan is awash in his 
immediate need to stop Linda from exposing their affair. Bogart further encourages Allan, "There are other things besides dames, and one of them is knowing you did the right thing for a pal."

Life can indeed become cinematic. For Allan, resolving his feelings for Linda is articulated through his love of the cinema. Allan finally catches up to Linda on the tarmac in front of Dick's plane. Linda acknowledges Allan's capability as a lover, "The most wonderful thing happened under our very noses, and you didn't have to do anything." Moreover, she admits to her love for Allan, a love that she does not regret but must stop for the sake of her relationship with Dick. Linda validates Alvy's adage that "relationships are crazy, irrational and absurd. But, we need the eggs" when she explains to Allan "Dick loves me, and in some inexplicable way, I need him." Allan agrees. Fog moves between them, obscuring the surroundings. Allan begins to recite Bogart's speech to Ilsa at the end of Casablanca, "You're a part of his world, what makes him tick. If you don't get on that plane..." Linda is struck by the beauty of Allan's words, and the camera cuts between them as they gaze knowingly into each other's eyes. Curiously, as a writer, Allan chooses to cite Casablanca rather than find his own words, but as he explains he's "been waiting [his] whole life to say that." Borrowing lines from Casablanca is less an issue of mimicry, than of Allan incorporating the cinematic references which have given his life meaning. Like Allan's approach to interior decorating, his citation indicates what Bogart describes as the little style that he's developed.

Casablanca is a playbook, or a perhaps a life book, for Allan. Nancy's remark that Allan is a great watcher is on point, but perhaps not the way she intended. Allan is one of life's great watchers: he has a unique ability to be open to the magic of cinema, and to experience its wonders again and again with continued awe and inspiration. Bogart as an imaginary friend, confident, and coach, bolsters Allan until the end, when Allan realizes that "[the] secret's not being you (Bogart). It's being me." And, Allan adds," I'm short enough and ugly enough to succeed on my own." The make believe friend, Bogart, 
made Allan believe. The aperture gained in the ultimate moments of the narrative for the nervous romantic is an ambivalent, if happy ending. The protagonist has had change in their thumping heart: from anxiety to excitement. Skipping a beat is no longer a sign of stressful palpitation, but once more a metaphor.

\section{Alvy: Will it Change My Wife?}

Alvy's heart continually palpitates. His transformation is less clear to map, as the film's conclusion leaves Alvy both happy and non-possessive toward Annie, but he also returns to a comforting ritual: watching the Sorrow and the Pity. It is unclear if it is Annie who is surprised by Alvy's expression of lurve, lo-ove, loff, love or if Alvy has surprised himself. The funny feelings between them are uncertain. The scene ends with the two kissing for a duration with their bodies straight, and faces covered from the camera. Alvy's playful words could be a comic rendition of sweet talking. As indicated when he invites Robin to "silently hump" while the intellectuals discuss modes of alienation, Alvy's way of wooing women is shades away from his stand-up routine. Nevertheless his expression intends to reach Annie, if not to sway her feelings with his feelings. Alvy's words are intended, in his own jokey way, to eroticize his polymorphously perverse partner. Marion (2007) remarks, "To speak in order to arouse to make ourselves go out of ourselves as flesh eroticized by words above all by words. This is what mouths are for, when they do not give themselves to kissing" (p. 146). Words touch when skin cannot. Annie's flesh may be eroticized; however, Alvy’s mouth struggles.

Love is a funny feeling which gives us a way to know the other. However, Alvy seeks not to know his beloved, but to have the security of love. The key question, for Alvy, is "do you love me?" He does not make the decision to be the first to love, but waits for confirmation from Annie that she does indeed love him. Alvy is willing to have Annie risk revealing her feelings, and extends his own tension 
of not knowing love. He waits until the last possible moment to speak of love, and still avoids the erotic reduction.

Alvy's request for affirmation: “do you love me” echoes his insecurity, and potential insincerity into the next scene. As Alvy waddles around with a cardboard box of framed pictures that he begins to set up, he protests "Whatta you mean. You're not gonna give up your own apartment, are you?" Annie worries that she is not smart enough to be taken 'seriously' by Alvy. To be taken seriously and to be serious about the relationship are two limits that Alvy skirts. If Annie has her own apartment, it functions like a "free floating life raft... that [they] know that [they're] not married." Living together is like being married and being married is death. To be married is death. To be serious is death. To be alive is to feel the tension of bubbling nervousness intensifying moments and to resist any security of knowing and loving. Instead, Alvy offers excuses, words to fill the silence, but not designed to reach or touch the other.

A love of letting be requires the assurance of loving without the return of love. Recall how in conducting the erotic reduction, the lover chooses to love, and dispenses with their worries if someone loves them or, as in the case of the cold feet, if they are worthy of love. Notably, Claude Romano's (2007) reading of Marion emphasizes love without being, or non-reciprocal love. By using obscuring language, Alvy reveals that he has resisted the erotic reduction and indicates that perhaps he is not yet ready to love.

Annie does eventually move in, but their domestic bliss is short lived. Alvy soon becomes paranoid that Annie is having an affair with her college professor, David, and they break-up awkwardly on a sunny street. Perplexed about love, Alvy approaches couples on the street to gain insight. Their responses should indicate to Alvy that no one's love life is simple, but requires understanding in the form of sexual compromise (the artificial stimulation of a large vibrating egg) and commonality (both 
partners are shallow). Though Annie and Alvy attempt to see other people, they reunite after Alvy's Kafka-esque experience with Pam (Shelley Duvall) ${ }^{39}$ when Annie needs help with an emergency: “a spider the size of a Buick." The two travel to California where Alvy is receiving an award, and Alvy finally consents to spending time with Tony Lacy. They attend a party at Tony's house where Annie enjoys herself and dances, while Alvy meanders from room to room observing the scene, and making wisecracks about the partygoers to Rob. On the plane ride back to New York, Alvy decrees that relationships, like sharks, must always move forwards, and decides that their relationship is a dead shark. As Annie packs her things, Alvy finds the copy of The Denial of Death that he bought her. Annie lets out a great sigh, "I feel like there is a great weight off my back." Though, Alvy plays it cool as Annie collects her items, as he leaves a movie theatre in the next scene he confesses that he misses her. Again, Alvy turns to the kind strangers on the street. He pulls from his pocket a bar of her black soap - whose purpose he does not understand, but still clutches in his hand as a reminder of their time together. A couple informs him that Annie has moved to California and now lives with Tony. As he begins to spurt and mutter, an old lady walks up to Alvy, and asks if he is jealous, to which he replies "a bit, like Medea."

After Annie and Alvy break up for the second time, Alvy recreates the conditions for romance with different women. But, while boiling lobster at the cottage and cracking jokes about the shellfish, it is Alvy who turns red, and not the lobster. He sets the conditions under which eros 'can' emerge, but still has not yet chosen to love. Alvy is seeking out assurance, and quips that "we still need the eggs", but he is still too chicken to love. Indeed, Alvy is a chicken, and needs to choose love. Replaying roles

\footnotetext{
${ }^{39}$ Curiously, it is only with Pam that Alvy finally makes love to a partner who neither requires drugs to relax, nor who makes intellectual excuses not to make love. It is once the love making is over that Pam comments to Alvy that making love to him is very Kafka-esque. For Pam, literature offers a way of understanding the experience at hand. But she is embodied and present enough in the experience to successfully make love to Alvy. Pam's ditzy demeanor coupled with her career as a reporter and namedropping, position her as mixture of Annie, Alison and Robin.
} 
over and over again is play at love; it is acting under the (dis)guise of love, without the living of love. Yet, it seems that by the film's end, Alvy has made progress.

The ultimate moments of Annie Hall illustrate the bitter-sweetness of a love of letting be. Alvy flies to California not only to see Annie, but to bring her back to New York. At a health food restaurant, over a plate of mashed yeast, Alvy is finally direct with Annie and adamantly asks "So you wanna get married or what?" Annie reminds Alvy that he was reason she got up in the mornings, could sing, and, generally, helped her come into her own. Annie's effects on Alvy are also clear: she helped him to relax and enjoy himself in everyday life, not simply to perform humor, but to try to live lightheartedly. Still, Annie wants to remain friends. The effects of renewal in Annie and Alvy's relationship were overshadowed by the elements of Pygmalion-Galatea in their relationship. In coming to terms with his own relationship to love, finally at the film's conclusion, Alvy is able to acknowledge his love for Annie. Despite their mutual love, their romantic relationship does not persist. Here Marion's words on the reciprocity of love are the most poignant. We cannot expect our love to be returned, but must love regardless.

In a final address to the camera, Alvy explains that he's worked things out through his art in a way that he could not in real life. And he tells us that he ran into Annie taking her new love interest to see The Sorrow and the Pity, which "[he] counted as a personal triumph." A montage of moments from their relationship builds to a crescendo of Alvy reflecting how he's realized what a terrific person she was and how it was fun just knowing her. In his own way, Alvy begins to love the possibility of love. Alvy nervously approaches romance, but does not go too far. The tension of the circularity, the flurry of feelings, and the questioning of the absurdity of life: this is what keeps Alvy piqued and his body alerted; a fight for meaning and a flight from letting go of his resignation to a circular argument against membership. 


\section{Cecilia: He's Not Real, But You Can't Have Everything}

The studio executives and the theatre manager are determined to get Tom back onto the screen, so he hides in the fairgrounds. Cecilia takes a moment to herself at the diner, and is confused when Tom makes an appearance. Though, it is not Tom who has come to dine, it is Gil Sheppard, the actor who plays Tom. Cecilia gushes over Gil, like the real movie star that he is. Gil takes a shining to Cecilia, and speaks to her "like a real person, not like a back set bimbo." Gil even takes her into a local music shop where the two perform a ukulele number, "I'm Alabamy bound," and as a token of affection, Gil buys her the ukulele. The two share stories, laugh, sing songs, and Gil insists that Cecilia move with him to Hollywood. Cecilia is caught in a love triangle between the real Hollywood actor Gil Sheppard and the Hollywood image Tom Baxter.

Cecilia visits Tom at the fairgrounds, and Gil follows her and confronts Tom. Mostly, Gil concerns himself with luring Cecilia away from Tom. Gil implores Cecilia, "Tell him that you don't love him. Tell him you can't love him. He's fictional." Cecilia recognizes the difference between a real and a reel man, yet it has no effect on her affections. She notes that Tom is "fictional, but you can't have everything." Gil further argues that Tom is not real, "and you can't learn to be real. It's like learning to be a midget. Some of us are real, and some of us are not." Cecilia is not persuaded by Gil, and Tom whisks her away from Gil. The two run away, and Tom decides to bring Cecilia into his own world.

Entering into the black-and-white screen, Cecilia is a foreigner. Though the colour drains from her body, there is no role for her in the plot of the film; she is extraneous. Gil enters the theatre surprised to see Cecilia on screen, and begins to confess that he cannot stop thinking about her. Cecilia and Tom return to the theatre to speak with Gil. Gil continues with his barrage of reasons why Cecilia should choose to be with him, over Tom: "You want to waste your time with a fictional character? I 
mean, you're a sweet girl, you deserve an actual human," "What good is perfect if you're not real?" and, "I have to have some time with you to show you what real life can be like if two people really care for each other." Overwhelmed by all of the attention, Cecilia sighs, "Last week I was unloved, now two people love me, and it's the same two people." Bearing witness to the feuding, the socialites begin to chime in. A voice off the screen shouts "Go with Gil because we are limited" and Rita urges Cecilia to go with Tom "he's got no flaws." Gil presses once more, and offers Cecilia not only a Hollywood romance, but love with a real flesh and blood person, "Come away with me to Hollywood, do something impulsive for once... I love you, I know that only happens in movies, but I do.” Convinced by Gil's efforts, Cecelia chooses Gil over Tom. She gently coos to Tom: "In your world things always have a way of working out right. I'm real, I need to choose the real world." Downhearted, Tom returns to the screen, the image is image once again, and the show goes on.

Cecilia packs her lone valise and her ukulele, and returns to the Jewel to meet Gil. Gil promised Cecilia a lavish Hollywood life, but sadly for Cecilia, Gil took notes from the same Hollywood script that Tom paraphrased to woo her. The Jewel's projectionist informs her that all the Hollywood executives have flown back, including Gil, who could not wait to leave after having saved his career. With Gil flying away first class back to the dream factory, Cecilia's dreams of romance are crushed.

But it is not only in Hollywood that things do have a way of working out. After being dumped by the real, but imperfect Gil Shepherd, and finally taking a stand against Monk, who "treats her rough... but still feels for her," Cecilia returns to a safe place refreshed and renewed. ${ }^{40}$ In the comforts of a matinee at the Jewel with Fred Astaire and Ginger Rogers swirling on screen in Top Hat (1935),

\footnotetext{
${ }^{40}$ In his comparison of Mickey and Cecilia, Blake (1995) assumes that Cecilia stays with Munk, and as a result of this assumption, argues that "Mickey goes beyond Cecilia in his discovery. Cecilia found a moment of escape that would allow her to endure another dose of hard reality with Monk. Mickey's moment of awareness allows him to transform his reality and find love and a meaningful purpose in his life" (p. 130).
} 
and music swelling "but it doesn't thrill me half as much as dancing cheek-to-cheek." The movie within the movie reiterates a valuable lesson: physical affection and an embrace is thrilling. Affection may be a thrill, but love for the cinema and love for the images that come before us and leave us is patiently sitting in the dark and holding space.

Another way of reading the situation between Tom and Cecilia is to posit Cecilia as an image for Tom. For Tom, Cecilia is an image on the other side of the flickering screen. She too appears in the scene when the film is about to begin and disappears after the credits. Cecilia, as real as she is, is a disappearing image for Tom. Certainly, Cecilia had every reason to fantasize her way out of her current circumstance. And yet, it was Tom Baxter who eagerly leaves the mad-cap Manhattan weekend he is about to embark on, in order to set off the screen to meet the woman that he loves. In her Sobchackinflected phenomenology of film—-material film, not simply cinema, Laura U. Marks' (2002) suggests that the materiality of film affords it a vulnerability. Not only is the image continually flickering, but it is decaying, the image is disappearing. Marks characterizes cinephilia as a love for a disappearing image. The contingency of the image and the impermanent relation with the image does not pose a challenge to a love of letting be, but rather underscores that a love of letting be is predicated on giving love until it is no longer possible, to offer an eschatological love (Marion, 2007) or to love until the end of time. Marks' (2002) comment that "Loving a disappearing image can be a way of rescuing something that was not loved in its own time" (p. 105) is particularly resonant here. Tom woos and romances Cecilia. Tom tries his best to love, what is for him, a disappearing image. In doing so, he rescues Cecilia from the grim immediacy of her reality. He offers her a reason and tangible reason to think beyond the depressed and limiting circumstances of her life. He acts out the on-screen hero in real life, as Cecilia negotiates the codes of playing not the damsel in distress--but the role of leading lady. 
Despite his role as a minor character, courage and chivalry have been written into Tom's script; where Cecilia is conditioned to doing what Monk wants. Together, Tom and Cecilia play in new ways. Cecilia realizes that she can be the object of someone's affection, learns to stand up for herself, and refuses Monk. Through her relationship with Tom, Cecilia chooses her role as a lover: as a whole person who is entitled to grow and develop. Tom rescues Cecilia by giving her hope for a better future, a future beyond the clutches of Monk where she is free to make her own choices.

\section{Mickey: It's lucky I ran into you}

A month transpires between Duck Soup igniting Mickey's passion for life, and a chance encounter with Holly. Having already decided on the pleasures of being "a part of something," Mickey's approach to Holly is less judgmental and kinder. While enjoying a late night stroll, Mickey spots Holly in a record shop and approaches her. Clad in a simple brown felt hat and matching wool coat, with her vintage jewelry paired down to a few pieces unlike the tangle of glitz she previously adorned, Holly is seemingly lighter. He finds her in the jazz section, having clearly just left the opera section as she is carrying Pagliacci and Don Giovanni records under her arm--indicating that Holly's post-punk tastes have mellowed. He initiates a conversation with a smirk, then teases, "I don't know if you remember me. We had the worst night of my life together."

They exchange jokes back and forth. Holly shyly confesses that she is writing something that could be a good television script, and asks if he would be willing to read what she has written. Mickey is humbled, laughs and adds that he does not understand why his opinion would mean anything to her, but is willing to read it. Holly presses, "Can I come over tomorrow and read it to you?" Mickey laughs, "I've been doing all my own reading since I was forty" ${ }^{41}$ but agrees to have her over. Holly adds, "I

${ }^{41}$ Alvy makes a similar joke while killing the spider the "size of a Buick" at Annie's. When Annie requests that after he kill the spider, he flush the toilet twice, he replies "I've been killing my own spiders since I was thirty." 
think it's lucky I ran into you, maybe."

Previously, Mickey could not even spare a moment for his sons' birthday, but he is now willing to spend an afternoon with someone he completely dismissed. To his surprise, the afternoon is enjoyable. As Holly concludes her reading, Mickey smiles, claps his hand, shakes his head, and slowly lets out: “I'm totally stunned...I'm amazed. It was great!” Holly requests that he be honest. Mickey continues, "You made my day. I was set to be bored stiff." Holly is touched by his positive response to her work, and asks to hear more about what he has been going through and "what made [him] decide to drop out of life." As the two enjoy lunch in a sunny window, jazz music plays over their conversation. After lunch they take a leisurely stroll through central park. Mickey describes his near mishap with the gun to Holly, and how his experience at the Metro theatre moved him to want to just be a part of it all. Holly notes that Mickey "really went through a crisis", to which he adds that he "really hit rock bottom." In choosing to be a part of life, in choosing love, Mickey's spirit is renewed after his crisis.

During Thanksgiving a year later, Holly helps her sisters with preparations. Mickey arrives late, and Holly greets him. Despite the bustle of the family, the two manage to remain alone in the foyer. With their bodies close together, the two whisper. Mickey is surprised to be returning to the family Thanksgiving dinner after having attended several dinners when married to Hannah, and then having assumed that his love life was over. Mickey lovingly gazes at Holly, "the heart is a very, very resilient muscle. A guy is married to one sister, then to another- how are you going to top that?" In her nervous squinty way, Holly announces to Mickey that she is pregnant. As the two embrace, a piano version of "I'm in Love Again" softly brings the film to a close.

For Mickey, there are two miracles that occur: he manages to avoid accidently killing himself, and he is able to conceive a child. Mickey's radical transformation, though ultimately occurring in the space of the cinema, was supported by his quest for answers. Mickey's loss of hearing, which read 
through the prism of nervousness and panic attacks, convinced him he was dying of a brain tumor. Like Allan and Alvy, Mickey has an acute awareness of bodily sensation and affect, and interprets his sensations to imply illness. It is through his experience in the cinema, that he is able to soothe his stress, and access the meditative experience that re-connected him to himself and to others around him. Through the meditative experience of the cinema, Mickey's solipsism is eroded.

The love that Mickey finds is made possible after he recognizes the presence of the other. This awareness was not previously possible for Mickey. Critical responses to Mickey’s transformation assume a division between irrational, joy, and love on the one hand, and rational intellect on the other. These responses neglect to consider that knowledge and the intellect can be informed by love and the experience of the body — that is, these responses forget that wisdom is enlightened by love. Writing on Hannah and her Sisters, Sander Lee (1997) writes: "Thus, somewhat surprisingly, Woody Allen, the New York intellectual, has presented us with a film that condemns over intellectualization" (p. 212). Lee (1997) is surprised by the film's conclusion that finds the previously miserable, sterile, pessimistic Mickey happy, in love, and married to a pregnant Holly. In Lee's (1997) reading of the film, Mickey drops his search for meaning in life, which is "a waste of time" in order to concede to the "acceptance of simple pleasures of family, love and faith" (p. 212). Similarly, James South (2004) critiques Allan for not elaborating the character's transformation more fully. For South (2004), Mickey's resolution is inconceivable: "Mickey realizes, on the basis of his emotional enjoyment of the Marx Brothers, that life might be worth living. So too, by ending the movie with the characters in love, Allen has suggested that love might be achievable and within our control. However, he has given us no reason to believe him" (p.129). Not only do Lee's (1997) and South's (2004) responses illustrate the division between passion and the intellect, but by suggesting that love is simple or that love is easily available to everyone they also reduce love to a frivolity. This position undermines an excavation of the complications of love that 
Mickey's vulnerability opens, and it exemplifies the gravity with which Marion (2007) writes that in polite company love is not spoken, and that Irigaray (2002) writes that we do not have a culture of love.

\section{Another Possibility}

Hannah and her Sisters affords an extended acquaintance with the newly transformed Mickey. His love and life affirming experience is crystallized through his relation with Holly and the conception of their child. Given the pessimistic readings of most Woody Allen films, perhaps accepting Mickey's change of heart is passable with the evidenced blossoming of his love for Holly. However, it may be the case that accepting the experience in the cinema as easily transforming Allan and Alvy is seemingly too naive, or too generous? Perhaps the narratives of Play it again, Sam and Annie Hall have not given the same evidence of transformation in Allan and Alvy that Hannah and her Sisters has with Mickey? Such a criticism is welcome.

Allan's lack of self-confidence and Alvy's antagonism in conjunction with their neurosis was understood as an obstacle to love. However, these obstacles did not prevent others from loving them. Allan and Alvy were caught up in the vanity of desperately seeking love, the situation that Marion phrases as "Does anyone out there love me?" Despite their own difficulty relaxing into love, engaging in the radical work of Marion's reduction, and asking "Can I love first", they were still loved by a lover. Marion offers to the lover who struggles to recognize themselves as a lover another way to come to terms with love through the lover. In experiencing the love of another lover, a person can come to recognize themselves as being able to love: "I wind up loving even myself because I have believed, seen, and experienced that I too, even I, could play the lover" (Marion, 2007, p. 214). The transition from wondering if "Anyone out there loves me" to "Can I love first" is initiated by the lover who already loves first. As Marion (2007) explains, a lover is witness to the foibles on the path toward love:

When I was advancing bewildered in my own advance, a blind lover not knowing whom to love or how, doubtless there were other lovers, senior to me, watching me, looking after my steps, and 
loving me already, without my knowledge in spite of me. In order for me to enter into the erotic reduction, it was necessary for another lover to have there before me, a lover who, from there, calls me there in silence. (p. 215)

Through the love of the lover, there is the possibility to understand oneself as a lover:

This time I indeed give myself over to the other, since I indeed receive myself entirely--as lover-from what I receive--her. I love even myself on the word of the other, who says she is my lover. I believe what she tells me more that what I have ever told myself. (p. 214)

Like Manhattan's Tracy who is upset when Isaac leaves her for a woman of his own age, and says "but you said you loved me," she recognized the potential in their relationship. It was only for Isaac to later discover that like Louis Armstrong's Potato Head Blues and Cezanne's Apples and Pears, Tracy's face is what makes life worth living. Tracy's naïveté is only skin deep, as it is she who understands that Isaac must first comes to understand his role as a lover — a role that she need not oversee — and that her primary responsibility is to develop herself and to enjoy tutelage in London. The silent, slackjawed, wide-eyed, hair-rubbing response of Isaac signals his coming to awareness of Tracy's capacity. In such cases, the lovers did not prepare themselves in advance of encountering the other, but it was the love of the other who facilitated their transition. As Marion (2007) writes: "The reduction did not at all result from my advance. In fact, without my knowing it, it preceded my advance" (p. 214). For Allan and Alvy through their encounters with Linda and Annie, and their meditative cinematic encounters, they begin to believe themselves lovers.

Allan, Alvy, and Cecilia suffer romantic loses, but continue to be open to love. The sensations the cinephile experiences in the cinema not only captured their attention, but deeply affected their understanding of their worlds. The cinema revealed the world anew. What we desire from film, as Robert Sinnerbrink (2013) argues, is know "how to regard the world with love" (p. 100). Cinema touches even the most timid of characters, like Allan who needs to borrow Bogart's lines such as "you are really something" to woo women, Alvy who stuttered through "I lurve you, I loaf you, I loff you 
with two f's", and Cecilia who was a shrinking violet. The cinema's sensational wonder inspires us to find in ourselves the openness to love. 


\section{Chapter 6: \\ Conclusion}

This dissertation begins with an anecdote about my own solitary experience in the cinema. The body of this work focused on the solitary experience of four exemplary cinephiles found in the cinema of Woody Allen. For each of us, our cinematic experiences, our experience engaging with the cinema enlightened our experience of love. For each of us, we had not, and perhaps could not have, anticipated what happened.

The arrival of the lover is unexpected, a surprise, and as a result can throw us off, destabilize us, turn us around. As Geschwandtner (2007) describes in her reading of Marion, love "is open to the other who unsettles and disturbs the self' (p. 228). This confusion is also present in Kristeva's (1987) account of describing love as une jeune fille, a young girl. Kristeva (1987) writes of a fiery madness, an experience so overwhelming that it can only be spoken of after the fact. But, even to speak of this experience after the fact poses its difficulties. As Kristeva (1987) notes "Trying to talk about it seems to me different from living it, but no less troublesome and delightfully intoxicating” (p. 2). Explaining the destabilizing force of the encounter of the lover is fraught with confusion. As Kristeva (1987) herself remarks, "Indeed, what are we talking about?" (p.2). This work has continually returned to slowly unfold the answer to the question: what are we talking about? Through the with-ness of transformation of Woody Allen's nervous romantics, the cinema has been located as a site of embodied enlightenment which brings an awareness of love as letting be that is premised on respecting and preserving the mystery of the enigmatic other.

An encounter between lovers, between others, is not subtle. To condemn Allan's spastic movements, Alvy's apprehension, Cecilia's shyness, or even Mickey's guardedness is to deny the power of the presence of the other. As the nervous romantic transitions into their embodied understanding of 
the role of the lover, the ego amans, their nervous condition dissipates, and they become aware of the wonder and the mystery of the other.

The lover catches us off-guard, and puts us into a vulnerable position where we do not know and cannot make claim to knowing what is before us. We can only recognize that we are there, before the other. We maintain a distance allowing a circulation of affection between us, returning us to ourselves, animating our bodies, enlightening our bodies.

To be surprised by the other; to be taken by their mystery; to maintain distance; to continually be open to putting oneself in question, and to putting the other in question; to ask: who am I and who are you? To rediscover each other anew; to turn to each other anew, and return to the self refreshed; to live the present as a seed of the future that is forever to be tended; to fumble and foible in earnest while trying to communicate love; to listen and to be still; these are the efforts of a love of letting be.

\section{Contribution}

In order to uncover the cinema as a site where a love of letting be was illuminated through the body, this work depended on locating a potential in the cinema of Woody Allen. The potential located in Allen's cinema was one of optimism, of transformation. In the haplessness of the nebbish schlemiel, renamed as the nervous romantic, I have recognized a sensitivity to the world which both exposes their fear of love and their reservation to love. Such an understanding is counter to the common academic responses of reading Woody Allen's work as pessimistic (Blake, 1995; Lee, 1997; South, 2004; Pogel, 1987), as suggesting the impossibility of love (Lee, 1997; Morris, 2013; Nichols, 2004; South, 2004), or even those which de-emphasize the centrality of love in Allen's work (Bailey, 2001; Bleiweiss, 2006; Morris, 2004; Hoesle, 2007; Hirsch, 1990).

Locating a love of the world in the cinema is exemplified in the writings of cinephiles and theorists Bazin and Epstein, but neither have brought to bare their cinematic experiences on life outside 
the cinema. Infusing everyday life with the bodily awareness attained in the cinema is unique to this work. Both the cinema and the cinephile have served as metaphors in coming to explain a love of letting be. In the space of the cinema there is a distance enacted between cinephile and screen, between others. This physical distance is a manifestation of the perceptual distance that characterizes a love of letting be as a crossed-phenomenon (Marion, 2007) or indirect love (Irigaray, 1996, 2001, 2002, 2008, 2013), but also is indicative of the interval or the ellipsis, where ellipsis is not an omission but a space, between others. The concept of the cinephile has served as a way to discuss a subject who is keenly aware of their embodiment, and who is tasked with approaching love from a stance of non-unity with a love of letting be.

\section{Review of Chapters}

The first chapter suggested, following Marion and Irigaray, that both philosophy and the dominant cultural perspective have forgotten the wisdom of love. Love has been debased from an embodied experience to a mere coupling, to a dependent unity. What is needed is to restore love's wisdom, a wisdom that is cultivated in the body and that returns individuals to care for themselves while they care for the other. Woody Allen's cinema offers examples of characters who are dissatisfied and fearful of a love of unity, but struggle with understanding love another way. Although they do not utter it, the nervous romantic seeks an alternative, a wisdom enlightened by love. The alternative to a love of unity suggested in this work is a love of letting be.

The second chapter sets out to offer a unique categorization of romantic relationships in Woody Allen's cinema. These categorizations, the sweet, the beat, the cheat, the heat, the repeat, and the cold feet, were based on close embodied readings of the films that sought to explore the films beyond the dichotomy of successful and unsuccessful relationships. The categorizations reflect how Woody Allen has positioned relationships between two people and how they regard each other. Further, this analysis 
located four exemplary characters, the nervous romantics, who underwent a transformation in how they understood love and how they loved.

In order to foreground the transformation of the nervous romantics, the third chapter explicates both the method of cinematic analysis and offers a deeper introduction to the nervous romantics. An overview of the phenomenology of cinematic experience was provided to make the method of cinematic experience and the method of analysis explicit. The second section of this chapter analyzed the nervous romantics and their romantic predicaments. The chapter positioned each of the nervous romantics as cinephiles, who were open to experiencing the cinema, but who concealed themselves from others.

The transformation of characters in the green world or the countryside is a common feature of the romantic comedy. However, for the characters of the nervous romance, cultural sites of creativity, specifically the cinema, encourage transformation. The embodied experience in the cinema enlightens the nervous romantic to consider their approach to love differently. The experience of the cinema invites cinephiles to open themselves to the experience of a love of letting be.

The final chapter considered the role of the erotic, the perceptions and sensations of the body, in cultivating a love of letting be. The embodied experience of the lover is their method and their gauge in coming to a love of letting be. Each of the nervous romantics develop, cultivate and arrive at a love of letting be uniquely. A love of letting be does not impose itself upon the lover, but encourages them to flourish in their own development.

\section{Implications}

Within contemporary love studies, Lauren Berlant (2006) has critiqued popular love, as being a love which is only told in one way: "first comes love, then comes..." This linear progression of love is akin to the Hollywood happy ending that validates the unification of the couple above all else. 
Similarly, Celestino Deleyto $(1998,2009)$ has charged romantic love with forgoing personal development by absorbing all other desires, including learning about the self. A love of letting be does not follow such a direct path, nor does it validate or valorize the couple. Indeed, a love of letting be dismisses the notion of marriage as the coming together of two to create a whole. Rather, a love of letting be encourages each individual to develop into themselves; thus, marriage becomes a source of continual refreshment and renewal toward the perpetuation of self-development. To be married or to be together is to commit to the continued preservation of mystery and distance between lovers. What is of utmost importance, is not union, but understanding the lover as a horizon which slips farther away, not to our detriment, but to our benefit. Sustaining our mystery, sustains our love.

\section{Suggestions for future research}

This work has reconsidered Woody Allen's approach to representing loving relationships. The meaning of life as connected to being open to love is another potential avenue for future research. In my analysis of Hannah and Her Sisters, I focus on Mickey's experience of Duck Soup as affirming his participation in life and love, but forego a discussion of his hypochondria and his life-altering diagnosis of good health that prompts him to 'drop out' of the television industry. Although Yacowar (2006) includes a brief analysis of death consciousness that includes mention of Ernest Becker's Denial of Death and Heidegger's Being and Time, a further analysis could explore the relationship between the affirmation of life and love in the Allen's cinema.

Further, a love of letting be is premised on the work of Irigaray and Marion, both of whom are indebted to the work of Emmanuel Levinas. In two instances Levinas makes reference to a non-allergic relation with the other. Within the context of Levinas' work, the notion of non-allergic receives no attention, rather is it simply a descriptor used to explain the face-to-face relationship with the other.

The initial occurrence of "allergic" arises when Levinas (1969) describes the "non-allergic relation with 
alterity" (p. 47). Indeed, the entire motive of Totality and Infinity is to work through this non-allergic relation. As Levinas (1969) clarifies: "the effort of this book is directed toward apperceiving in discourse a non-allergic relation with alterity, toward apperceiving Desire" (p. 47). There is not a lack of allergy to the other, but the relationship is non-allergic.

What of this non-allergic relationship with alterity? Does this imply the immanent physical presence of the other causes a physical manifestation of dis-ease? If to be allergic is to be harmed by a substance that is typically understood not to be harmful, then for something to be non-allergic is to imply that it cannot be harmful. To extrapolate this analog, if the relation with the other is allergic, then the other causes harm; however, if the relation to the other is non-allergic, then the other does not cause harm. My particular interest in this description lies not with its implication that the relation must not be harmful, but that an allergy is pre-disposition toward something harmful. To suggest that the relationship to the other is non-allergic is to suggest that what manifests in me is hospitality toward the other. While Derrida has written on hospitality in Levinas (1999) and has also considered immunity, he has not concentrated on the notion of the allergic in Levinas. This notion of the non-allergic could be a fruitful expansion of the notion of a love of letting be.

\section{Final note}

As a final note, I want to return to the space of the cinema, where this inquiry began. Sitting on the velvet seats, awaiting the parting of the velvet curtains, the anticipation of the film is fortified and no matter how wonderful or terrible the film, it will be completed within the span of a few hours and the curtains will close. In encountering the other, we must prepare ourselves for the continual parting of velvet curtains that do not close, but forever reveal the other anew. Is to the continual parting of curtains that we must prepare, and that we must love. 


\section{References}

Abbot, S. and Jermyn, D. (2009). A Lot Like Love: The Romantic Comedy in Contemporary

Cinema. In Stacey Abbott and Deborah Jermyn. (Eds) Falling in Love Again: Romantic

Comedy in Contemporary Cinema. (pp.1-8). London and New York: I.B. Tauris.

Allen, W. (1982). Four films of Woody Allen. New York: Random House.

Ames, C. (2013). Jazz Heaven: Woody Allen and the Hollywood Ending. In Bailey, P. J. and Girgus, S.B. (Eds.) A Companion to Woody Allen. (pp. 207-226) Malden, MA: Wiley

Andrew, D. (1985 [1978]). The Neglected Tradition of Phenomenology in Film Theory. In Bill Nichols (Ed.) Movies and Methods Vol. II. (pp. 625-631). Berkeley and Los Angeles: University of California Press.

Antler, J. (2007). You never call! You never write!: A history of the Jewish mother. Oxford: Oxford University Press.

Ascione, L. (2004). Dead sharks and dynamic ham: The philosophical use of humor in Annie Hall. In Mark T. Conrad and Aeon T. Skoble (Eds.) Woody Allen and Philosophy: You mean my whole fallacy is wrong. (pp.132-150). Chicago and La Salle, Illinois: Open Court.

Aragon, L. ([1918] 1988). On Décor. French film theory and criticism: a history/anthology 1907-

1939. R. Abel (Ed.) (p.241-246). Princeton, N.J.: Princeton University Press.

Bailey, P. J. (2001). The Reluctant Film Art of Woody Allen. Lexington: The University of Kentucky Press.

Berlant, L. (1998). Introduction. Intimacy: A special issue. Critical Inquiry. 24(2) pp. 281-288 (2006). Cruel Optimism. differences: A journal of feminist cultural studies. 17(3) doi 10.1215/10407391-2006-009 
Bainbridge, C. (2009). A feminine cinematics: Luce Irigaray, Women and Film. New York, NY: Palgrave Macmillan.

Bazin, A. (1971). De Sica: Metteur on Scène. What is Cinema? Vol. II. Trans. Hugh Gray. (pp. 61-78). Berkley and London: University of California Press.

(1971). Ontology of the Photographic Image. What is Cinema? Vol. II. Trans. Hugh Gray. (pp. 3-12). Berkley and London: University of California Press.

Bazin, A. (2005a[1967-1971]). The Ontology of the Photographic Image In Gray H. (Ed.), What is cinema? Vol. I (pp. 9-12) Berkeley: University of California Press. (2005b[1967-1971]). Bicycle Thief. In Hugh Gray (Ed.) What is Cinema? Vol II. (pp. 47-60) Berkeley: University of California Press. (2005c[1967-1971]). De Sica: Metteur en Scene. What is Cinema? Vol II. (pp. 61-78) Berkeley: University of California Press.

Bolton, L. (2011). Film and female consciousness: Irigaray, cinema and thinking women. New York, NY: Palgrave Macmillan.

Blake, R. A. (1995). Woody Allen: Profane and Sacred. Lanham and London: The Scarecrow Press. Bleiweiss, C. (2006). Self-deprecation and the Jewish humor of Woody Allen. In Charles Silet (Ed.) The Films of Woody Allen. Critical Essays. (pp. 58-77) Lanham, Maryland: The Scarecrow Press Inc.

Bjorkmann, S. and Allen, W. (1993). Woody Allen on Woody Allen. (Revised Edition.) Stig Bjorkmann (Ed.) London: Faber \& Faber.

Brown, D. (2006). Powerful man gets pretty woman: Style switching in Annie Hall. In Charles Silet (Ed.) The Films of Woody Allen. Critical Essays. (p. 112-122) Lanham, Maryland: The Scarecrow Press Inc. 
Cardullo, B. (2006). Autumn Interiors, or the ladies eve: Woody Allen's Bergman complex. In Charles Silet (Ed.) The Films of Woody Allen. Critical Essays. (pp. 133-144) Lanham, Maryland: The Scarecrow Press Inc.

Casebier, A. (1991). Film and Phenomenology. Toward a Realist Theory of Cinematic Representation. Cambridge: Cambridge University Press.

Cavell, S. (1981). Pursuits of Happiness. Cambridge, MA: Harvard University Press.

Cohen, A.J. (2004). Woody Allen and Freud. In Jerrold R. Brandell (Ed.) Celluloid couches, cinematic clients. Psychoanalysis and psychotherapy in the movies. (p. 127-146) Albany, NY: State University of New York.

Cowie, P. (1996). Annie Hall. London: British Film Institute.

Critchley, S. (2002). Introduction. In Simon Critchley and Robert Bernasconi (Eds). The Cambridge Companion to Levinas. Cambridge: Cambridge University Press.

Curry, R. R. (1996). Perspectives on Woody Allen. New York, NY: G.K. Hall \& Co. An Imprint of Simon and Schuster MacMillan.

del Mar Asensio Arostegui, M. (2006). Hlenka regained: Irony and ambiguity in the narrator of Woody Allen's Another Woman. In Charles Silet (Ed.) The Films of Woody Allen. Critical Essays. (pp. 256-267). Lanham, Maryland: The Scarecrow Press Inc.

Deleyto, C. (2009). The Secret Life of the Romantic Comedy. Manchester and New York: Manchester University Press.

(1998). "Love and other triangles: Alice and the Conventions of Romantic Comedy". In Peter William Evans and Celestino Deleyto (Eds). Terms of Endearment. Hollywood Romantic Comedy of the 1980's and 1990's. (pp.129-147) Edinburgh: Edinburgh University Press. (2006) The narrator and the narrative: the evolution of Woody Allen's film comedies. In 
Charles Silet (Ed.) The Films of Woody Allen. Critical Essays. (p. 21-33). Lanham, Maryland: The Scarecrow Press Inc.

Desser, D. and Friedman, L.D. (2004). Jewish American Filmmakers. Urbana, University of Illinois.

Derrida, J. (1999). Adieu to Emmanuel Levinas. Pascale-Anne Brault and Michael Nass (trans.) Stanford, CA: Stanford University Press.

Detmer, D. (2004). Inauthenticity and personal identity in Zelig. In Mark T. Conrad and Aeon T. Skoble (Eds.) Woody Allen and Philosophy: You mean my whole fallacy is wrong. (pp. 186202). Chicago and La Salle, Illinois: Open Court.

(2013). The philosopher as filmmaker. In Bailey, P. J. and Girgus, S.B. (Eds.) A Companion to Woody Allen. (pp. 460-480) Malden, MA: Wiley

De Valck, M. and Hagener, M. (2005). Cinephilia: Movies, love, and memory. Amsterdam University Press.

Elasser, T. (2005). Cinephilia or the uses of disenchantment. In De Valck, M. and Hagener, M. (Eds). Cinephilia: Movies, love, and memory. (pp. 27-44). Amsterdam University Press.

Epstein, J. (1988 [1921]). Magnification. French film theory and criticism: a history/anthology 19071939. R. Abel (Ed.) (p.235-240). Princeton, N.J.: Princeton University Press. (1988 [1921]). The Senses I. French film theory and criticism: a history/anthology 1907- 1939. R. Abel (Ed.) (p.241-246). Princeton, N.J.: Princeton University Press. (1988 [1924]). On certain characteristics of photogenie. French film theory and criticism: a history/anthology 1907-1939. R. Abel (Ed.) (p.314-318). Princeton, N.J.: Princeton University Press.

(2012 [1921]). Bonjour Cinema. Jean Epstein. Critical Essays and New Translations. Sarah Keller and Jason N. Paul (Eds.) (p. 277) Amsterdam: Amsterdam University Press. 
(2012 [1922]). La Lyrosophie. Jean Epstein. Critical Essays and New Translations. Sarah Keller and Jason N. Paul (Eds.) (p. 281-287) Amsterdam: Amsterdam University Press.

Epstein, L.J. (2001). The Haunted Smile: The Story of Jewish Comedians in America. New York: Public Affairs.

Feuer, M. (2013). The Schlemiel in Woody Allen's later films. In Bailey, P. J. and Girgus, S.B. (Eds.) A Companion to Woody Allen. (pp. 403-423) Malden, MA: Wiley.

Freud, S. (1977). Three essays on the theory of sexuality. In J. Strachley (Ed. \& Trans.), The standard edition of the complete psychological works of Sigmund Freud. Vol. 7 (pp. 45-145). New York: Penguin Books.

(1977). A special type of choice of object made by men (Contributions to the psychology of love 1) (1910). In J. Strachley (Ed. \& Trans.), The standard edition of the complete psychological works of Sigmund Freud. Vol. 7 (pp. 227-242). New York: Penguin Books. (1977). On the universal tendency to debasement in the sphere of love (Contributions to the psychology of love 11) In J. Strachley (Ed. \& Trans.), The standard edition of the complete psychological works of Sigmund Freud. Vol. 7 (pp.243-260). New York: Penguin Books. (1960). Jokes and their relation to the unconscious. New York: Norton.

Fox, J. (1996). Woody: Movies from Manhattan. London: B.T. Batsford.

Frampton, D. (2006). Filmosophy. London: Wallflower Press.

Gehring, W.D. (2006). Woody Allen and fantasy: Play it again, Sam. In Charles Silet (Ed.) The Films of Woody Allen. Critical Essays. (pp. 89-99) Lanham, Maryland: The Scarecrow Press Inc.

Geschwandtner, C. M. (2007). Reading Jean-Luc Marion: Exceeding Metaphysics. Bloomington and Indianapolis: Indiana University Press. 
Glenn. C. (2013). Which Woody Allen? in Bailey, P. J. and Girgus, S.B. (Eds.) A Companion to Woody Allen. (pp. 35-52) Malden, MA: Wiley.

Girgus, S. (2002). The films of Woody Allen. New York and Cambridge: Cambridge University Press.

(2013). Afterword: The abyss: Woody Allen on love, death and God. In Bailey, P. J. and Girgus, S.B. (Eds.) A Companion to Woody Allen. (pp. 559-572) Malden, MA: Wiley

Gregg, M. \& Siegworth, G. (2010). An Inventory of Shimmers. The Affect Theory Reader. Duke University Press.

Grindon, L. (2011). The Hollywood Romantic Comedy: conventions, history, controversies. Malden, MA: Wiley-Blackwell.

Grosz, E. (1994). Volatile Bodies. Bloomington, Indiana: Indiana University Press.

Golden, H. (1972). The Golden Book of Jewish Humor (1972) New York: G.P. Putnam and Sons.

Gordon, J. (2004). Self knowledge in Another Woman. In Mark T. Conrad and Aeon T. Skoble (Eds.) Woody Allen and Philosophy: You mean my whole fallacy is wrong. (pp. 128-142). Chicago and La Salle, Illinois: Open Court.

Hegel, GW.F. (1977). Phenomenology of Spirit. (A.V. Miller Trans.) Oxford: Clarendon Press. Henderson, B. (1978). Romantic Comedy Today: Semi-Tough or Impossible? Film Quarterly 31(4) doi: $10.2307 / 1211803$ p.11-23

Hirsch, F. (1990). Love, sex, death \& the meaning of life: the films of Woody Allen. New York: Limelight Editions.

Hösle, V. (2007). Woody Allen: an essay on the nature of the comical. Notre Dame, Indiana: University of Notre Dame Press.

Horner, R. (2007). The weight of love. In K. Hart (Ed.), Counter experiences: Reading Jean-Luc 
Marion. (pp. 235-254). Notre Dame, IN: Notre Dame University Press.

Ihde, D. (2012). Experimental phenomenology: Multistabilities (2nd ed. ed.). Albany: State University of New York Press.

Ince, K. (1996). "Questions to Luce Irigaray". Hypatia. 11(2). p. 122-140. Retrieved from http://www.academia.edu/747661/Questions_to_Luce_Irigaray

Irigaray, L. (1991). "Questions to Emmanuel Levinas. On the Divinity of Love". In Margaret Whitford (Ed.) The Irigaray Reader. (pp. 178-189). Oxford and Cambridge: Blackwell. (1996). I love to you. Sketch for a Felicity Within History. (A. Martin, Trans.) New York and London: Routledge.

(2001). To be two. (Trans. Monique M. Rhodes and Marco F. Cocito-Monoc) New York: Routledge. (2002). The way of love. (Trans. Heidi Bostic and Stephen Pluhacek) London: Continuum. (2008). Sharing the world. New York and London: Continuum.

(2013). In the beginning she was. London and New York: Routledge. (2008). Conversations. Luce Irigaray with Stephen Pluháček and others. London and New York: Continuum.

Jeffers McDonald, T. (2007). Romantic Comedy: Boy Meets Girl Meets Genre. London and New York: Wallflower Press.

King, G. (2002). Film Comedy. London and New York: Wallflower Press.

King, K. (2001). Woody Allen: A Casebook. London, New York: Routledge.

Kirtland, K. (2012). The Cinema of the Kaliedoscope. in Sarah Keller and Jason N. Paul (Eds.) Jean Epstein. Critical Essays and New Translations. (p. 93-114). Amsterdam: Amsterdam University Press. 
Knight, C. J. (2013). "Raging in the dark": Late style in Woody Allen's Films. In Bailey, P. J. and Girgus, S.B. (Eds.) A Companion to Woody Allen. (pp. 73-94). Malden, MA: Wiley.

Krutnik, Frank. (1990) The Faint Aroma of Performing Seals: The "Nervous" Romance and the Comedy of the Sexes. Velvet Light Trap. 26. Pp. 57-72. Retrieved June 12, 2014 (2009). Love Lies: Romantic Fabrication in Contemporary Romantic Comedy. In Stacey Abbott and Deborah Jermyn (Eds). Falling in Love Again: Romantic Comedy in Contemporary Cinema. (pp. 15-36). London and New York: I.B. Tauris. (2002). Conforming Passions: Contemporary Romantic Comedy. in Steve Neale (Ed). Genre and Contemporary Hollywood. (pp.130-149). London: British Film Institute.

Kristeva, J. (1987). Tales of Love. Leon S. Roudiez (Trans.). New York: Columbia University Press. (1995). New maladies of the soul. Ross Guberman (Trans.) New York: Columbia University Press.

Laine, T. (2011). Feeling cinema: Emotional dynamics in film studies. New York: Continuum. Lax, E. and Allen, W. (2009). Conversations with Woody Allen: His film, the movies, and moviemaking. New York: Alfred A. Knopf.

Lee, S. H. (1997). Woody Allen's Angst. Philosophical Commentaries on His Serious Films. Jefferson, North Carolina and London: McFarland \& Co. Inc. Publishers (2004). The dangers of hedonism: A Midsummer Night's Sex Comedy. In Mark T. Conrad and Aeon T. Skoble (Eds.) Woody Allen and Philosophy: You mean my whole fallacy is wrong. (pp. 169-185). Chicago and La Salle, Illinois: Open Court. (2013). Love, Meaning, and God in the later films of Woody Allen. In Bailey, P. J. and Girgus, S.B. (Eds.) A Companion to Woody Allen. (pp. 504-519) Malden, MA: Wiley 
Lehtinen, V. (2014). Luce Irigaray's Phenomenology of Feminine Being. Albany: State University of New York Press

Levinas, E. (1969). Totality and Infinity. Translated by Alphonso Lingus. Pittsburgh: Duquesne University Press.

(1985). Ethics and infinity: Conversations with Philippe Nemo. (R.A. Cohen, Trans.).

Pittsburgh: Duquesne University Press.

Librach, R. S. (1996). A portrait of the artist as a neurotic: studies in interior distancing in the films of Woody Allen. In Curry, Renee. R. (Ed.) Perspectives on Woody Allen. (p 158-176) New York, NY: G.K. Hall \& Co. An Imprint of Simon and Schuster MacMillan.

Livingston, P. (2006). Theses on cinema as philosophy. The Journal of Aesthetics and Art

Criticism,64(1), 11-18. doi: 10.1111/j.0021-8529.2006.00225.x

MacDowell, J. (2013). Happy Endings in Hollywood Cinema. Cliché, Convention and the Final Couple. Edinburgh: Edinburgh University Press.

Marion, J.L. ([1994] 2002). What Love Knows. In The prolegomena to charity. (S. E. Lewis, Trans.) (pp.153-180). New York: Fordham University Press.

(2007). The erotic phenomenon. (S. E. Lewis, Trans.) Chicago and London: University of Chicago Press.

Marks, L. (2002). Touch: Sensuous Theory and Multisensory Media. Minnesota: University of Minnesota Press.

(2000). The Skin of the Film: Intercultural Cinema, Embodiment, and the Senses. Durham: Duke University Press.

Massumi, B. (2002). Parables for the virtual: Movement, affect, sensation. Durham, NC: Duke University Press. 
Mast, G. (1979). The comic mind: comedy and the movies. Chicago: University of Chicago Press. Merleau-Ponty, M. (1964). The cinema and the new psychology. In H. L. Dreyfus and P.A. Dreyfus (Eds.) Sense and non-sense. (pp. 48-62). Evanston, Illinois: Northwestern University Press. (2004). The world of perception. Trans. Oliver Davis. London and New York: Routledge. Milbank, J. (2007). The Gift and the Mirror: On the Philosophy of Love. In K. Hart (Ed.) Counter experiences: Reading Jean-Luc Marion. (p.253-318). Notre Dame, IN: Notre Dame University Press

Morris, T. (2004). Foreward: Can we not talk about sex all the time. In Mark T. Conrad and Aeon T. Skoble (Eds.) Woody Allen and Philosophy: You mean my whole fallacy is wrong. (pp. 1-4) Chicago and La Salle, Illinois: Open Court.

Morris, C. (2006). Woody Allen's comic irony. In Charles Silet (Ed.) The Films of Woody Allen. Critical Essays. (pp. 58-77) Lanham, Maryland: The Scarecrow Press Inc.

Mortimer, C. (2010). Romantic Comedy. New York and London: Routledge.

Mullarkey, J. (2011). Films Can't Philosophise (and neither can philosophy): Introduction to a NonPhilosophy of Cinema. In Hari Carel and Greg Tuck (Ed.) New Takes on Film Philosophy (pp. 86-201). London: Palgrave Macmillan.

Munsterburg, H. (1916). The photoplay: A psychological study. New York: Appleton.

Neale, S. and Krutnik, F. (1990). Popular Film and Television Comedy. London and New York: Routledge.

Nichols, M.P. (1998). Reconstructing Woody: art, love, and life in the films of Woody Allen. Lanham, MD: Rownman \& Littlefield. 
(2004). Woody Allen's film noir: Crime, love, and self-knowledge in The Curse of the Jade

Scorpion. In Mark T. Conrad and Aeon T. Skoble (Eds.) Woody Allen and Philosophy: You mean my whole fallacy is wrong. (pp. 143-158) Chicago and La Salle, Illinois: Open Court.

Pinsker. S. (2006). Woody Allen's Loveable Anxious Schlemiels. In Charles Silet (Ed.) The Films of Woody Allen. Critical Essays. (pp. 1-12). Lanham, Maryland: The Scarecrow Press Inc.

Plato (2000). Symposium. (T. Griffith, Trans.) New York: A.A. Knopf.

Polhemus, R.M. (2013). Comic Faith and Its Discontents: Death and the late Woody. In Bailey, P. J. and Girgus, S.B. (Eds.) A Companion to Woody Allen. (pp. 116-144 ). Malden, MA: Wiley. Pogel, N. (1987). Woody Allen. Boston: Twayne.

Rapf, J. E. (2013). “It’s complicated, really": Women in the films of Woody Allen. In Bailey, P. J. and Girgus, S.B. (Eds.) A Companion to Woody Allen. (pp. 257-276) Malden, MA: Wiley.

Raskin, R. (2007, February). The original function of Groucho Marx's Resignation Joke. 16: 9 Filmditsskrift. 20. Retrieved from: http://www.16-9.dk/2007-02/side11_inenglish.htm

Rosten, L. (1970). The Joys of Yiddish Humor. New York: Pocket Books.

Rowe, K. (2011). The Unruly Woman: Gender and the Genres of Laughter. Austin: University of Texas Press.

Romano, C. (2007). Love in its concept: Jean-Luc Marion's The Erotic Phenomenon. In K. Hart (Ed.) Counter experiences: Reading Jean-Luc Marion. (pp. 319-338). Notre Dame, IN: Notre Dame University Press.

Sartre, J-P. (1956). Concrete relations with others. Hazel Barnes (Trans.) Being and nothingness (pp.471-534). New York: Washington Square Press.

Sayad, C. (2013). The stand-up auteur. In Bailey, Peter. J. and Girgus, Sam. B. (Eds.) A Companion to Woody Allen. (pp. 15-34). Malden, MA: Wiley. 
Schatz, T. (2006). Annie Hall and the issue of modernity. In Charles Silet (Ed.) The Films of Woody Allen. Critical Essays. (pp. 123-132) Lanham, MD: The Scarecrow Press Inc.

Stewart, K. (2007). Ordinary affects. Durham, NC: Duke University Press.

Sisco King, C. (2013). Play it again, Woody: Self-Reflexive Critique in Contemporary Woody Allen Films. In Bailey, P. J. and Girgus, S.B. (Eds.) A Companion to Woody Allen. (pp. 188-206) Malden, MA: Wiley

Singer, I. (1998). Reality transformed: Film as meaning and technique MIT Press.

Sinnerbrink, R. (2011a). New philosophies of film: Thinking images. New York: Continuum.

(2011). "Re-Enfranchising Film: Toward a Romantic Film-Philosophy". in H. Carel and G. Tuck. New Takes on Film Philosophy. (pp. 25-47) London: Palgrave Macmillan.

(2013). Cinematic Belief. Angelaki 17(4) pp 95-117 doi: 10.1080/0969725X.2012.747332

Snow, D. (2006). Woody Allen's Interiors: The dark side of Hannah and Her Sisters. In Charles Silet (Ed.) The Films of Woody Allen. Critical Essays. Lanham, Maryland: The Scarecrow Press Inc. $(240-249)$

Sobchack, V. (1992). The address of the eye: A phenomenology of film experience. Princeton, N.J. Princeton University Press.

(2004). Carnal thoughts: Embodiment and moving image culture. Berkeley: University of California Press.

(2008) "Embodying transcendence: On the literal, the material, and the cinematic sublime." Material Religion. 4 (2) p.194-203 doi: 10.2752/175183408X328307

(2011). Fleshing out the Image: Phenomenology, pedagogy and Derek Jarman's Blue. in H. Carel and G.Tuck. New Takes on Film Philosophy. p. 191-206 London: Palgrave Macmillan. 
Sontag, S. (1996, February 15). The decay of cinema. The New York Times. Retrieved March 19, 2015 from https://www.nytimes.com/books/00/03/12/specials/sontag-cinema.html

South, J. (2004). "You don't deserve Cole Porter": Love and music according to Woody Allen. In Mark T. Conrad and Aeon T. Skoble (Eds.) Woody Allen and Philosophy: You mean my whole fallacy is wrong. (pp.118-130). Chicago and La Salle, Illinois: Open Court.

Stacey, J. (1993). Star-Gazing: Hollywood cinema and female spectatorship. London: Routledge. Stillwell, R. J. (2009). Music, Ritual and Genre in Edward Burns' Indie Romantic Comedies. in Falling in Love Again. Romantic Comedy in Contemporary Cinema. Stacey Abbott and Deborah Jermyn Eds. (pp. 25-37). London and New York: I.B. Tauris.

Spignesi, S. J. (1992). The Woody Allen Companion. Kansas City, MO: Andrews and McMeel.

Todd, E. (2014). Passionate Love and Popular Cinema. Romance and Film Genre. London: Palgrave MacMillan.

Trahair, L. (2007). The Comedy of Philosophy. Sense and Nonsense in Early Cinematic Slapstick. New York: State University of New York Press.

Wall-Romana, C. (2012). Epstein's Photogenie as corporeal vision: Inner sensation, queer embodiment, and ethics. Jean Epstein. Critical Essays and New Translations. Sarah Keller and Jason N. Paul (Eds.) (pp. 51-72) Amsterdam: Amsterdam University Press.

Wernblad, A. (1992). Brooklyn is not expanding: Woody Allen's comic universe. Rutherford, NJ: Farleigh Dickinson University Press.

Wartenburg, T. E. (2011) On The Possibility of Cinematic Philosophy. in in H. Carel and G. Tuck. New Takes on Film Philosophy. (pp. 9-24) London: Palgrave Macmillan. (2008). Thinking on Screen. Film as Philosophy. London and New York: Routledge. 
(1999). Unlikely couples: movie romance as social criticism. Boulder, Co: Westview Press.

Yacowar, M. (1979). Loser Take All. The Comic Art of Woody Allen. New York: Frederick Ungar Publishing Co.

(2006). Beyond Parody: Woody Allen in the 1980's. In Charles Silet (Ed.) The Films of Woody Allen. Critical Essays. (pp. 78-88). Lanham, Maryland: The Scarecrow Press Inc. 